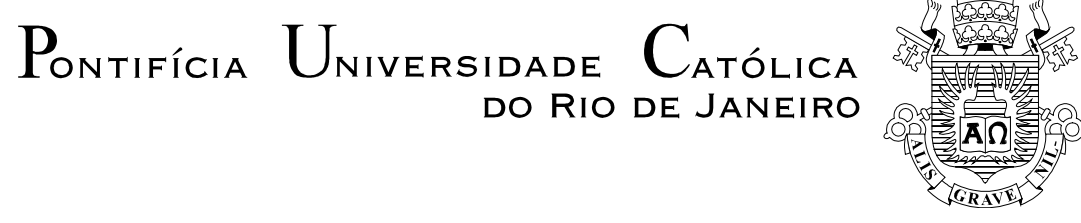

Thiago Cavalheiro Tavares

\title{
Adaptação do Modelo de Edificação Passivhaus em Climas Quentes
}

\section{Dissertação de Mestrado}

Dissertação apresentada ao Programa de Pósgraduação em Engenharia Urbana e Ambiental do Departamento de Engenharia Civil da PUC-Rio como requisito parcial para obtenção do título de Mestre em Engenharia.

Orientador: Prof. Antônio Roberto Martins Barboza de Oliveira

Rio de Janeiro

Agosto de 2016 


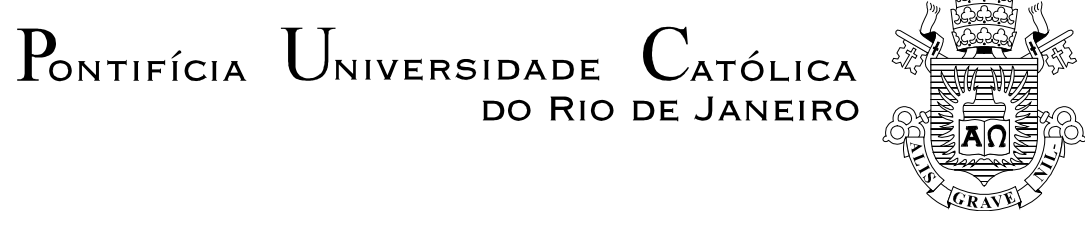

THIAGO CAVALHEIRO TAVARES

\section{Adaptação do Modelo de Edificação Passivhaus em Climas Quentes}

Dissertação apresentada como requisito parcial para obtenção do título de Mestre em Engenharia Urbana e Ambiental (opção profissional) pelo

Programa de Pós-Graduação em Engenharia Urbana e Ambiental da PUC-Rio. Aprovada pela Comissão Examinadora abaixo assinada.

Prof. Antônio Roberto Martins Barboza de Oliveira

Presidente

Departamento de Engenharia Civil - PUC-Rio

Profa. Claudia Mariz de Lyra Barroso Krause

UFRJ

Prof. Marcelo Roberto Ventura Dias de Mattos Bezerra Departamento de Arquitetura e Urbanismo

PUC-Rio

Prof. Márcio da Silveira Carvalho Coordenador Setorial de Pós-Graduação do Centro Técnico Científico - PUC-Rio

Rio de Janeiro, 24 de agosto de 2016. 
Todos os direitos reservados. É proibida a reprodução total ou parcial do trabalho sem autorização da universidade, do autor e do orientador.

\section{Thiago Cavalheiro Tavares}

Graduou-se em Engenharia Ambiental (Universidade Veiga de Almeida) em 2014, obtendo o título de pós-graduação em Engenharia Sanitária e Ambiental da Universidade Federal do Rio de Janeiro (UFRJ) em 2015. Atualmente atua como consultor técnico de meio ambiente para empresas de construção e saneamento.

Ficha Catalográfica

Tavares, Thiago Cavalheiro

Adaptação do modelo de edificação Passivhaus em climas quentes / Thiago Cavalheiro Tavares ; orientador: Antônio Roberto Martins Barboza de Oliveira. - 2016.

133 f. : il. color. ; $30 \mathrm{~cm}$

Dissertação (mestrado)-Pontifícia Universidade Católica do Rio de Janeiro, Departamento de Engenharia Civil, Programa de PósGraduação em Engenharia Urbana e Ambiental, 2016.

Inclui bibliografia

1. Engenharia Civil - Teses. 2. Engenharia Urbana e Ambiental Teses. 3. Passivhaus. 4. Resfriamento por absorção. 5. Construções sustentáveis. 6. Condições de conforto. I. Oliveira, Antônio Roberto Martins Barboza de. II. Pontifícia Universidade Católica do Rio de Janeiro. Programa de Pós-Graduação em Engenharia Urbana e Ambiental. III. Título. 
Dedico essa dissertação aos meus pais, Cristiane Cavalheiro e Leolindo Tavares, que me deram forças e me apoiaram, até o último momento. 


\section{Agradecimentos}

Primeiramente, agradeço a Deus pela proteção e segurança que me forneceu ao longo desta caminhada.

A minha mãe, Cristiane Cavalheiro, por além de ser minha mãe, ser minha melhor amiga e possuir um amor incondicional por mim, me ensinando os valores da vida.

Ao meu pai, Leolindo Tavares, por ser um pai presente nos momentos mais difíceis, ajudando da melhor maneira possível.

A minha bisavó Carmen, que está ausente fisicamente, mas a todo tempo presente em minha vida.

Ao meu avô, Carlos Alberto, pelo seu acompanhamento no início de minha carreira acadêmica.

Ao Dante, meu fiel companheiro, estando em todos os momentos comigo, doando seu tempo, atenção e carinho.

As minhas avós, Fátima e Helena, que continuam cuidando de mim até hoje.

Ao meu tio Máximo, pela experiência em edificações e conhecimentos na área de arquitetura sustentável.

A Roberta, por estar ao meu lado nesta caminhada, compreendendo minha ausência em determinados momentos da vida.

Aos integrantes da Cultive Soluções, Marcelo, Thiago e Diego, pela dedicação e esforço na busca de tecnologias sustentáveis.

Ao professor Antônio Roberto, meu orientador, por ter me cedido seu laboratório para realizar minhas pesquisas, além de fornecer ensinamentos constantes que culminaram à esta etapa.

A todos os meus colegas de mestrado.

A todos os professores deste curso, por dispor de ensinamentos e experiências profissionais. 


\section{Resumo}

Tavares, Thiago Cavalheiro; Oliveira, Antônio Roberto Martins Barboza de (Orientador). Adaptação do Modelo de Edificação Passivhaus em Climas Quentes. Rio de Janeiro, 2016. 133p. Dissertação de Mestrado Departamento de Engenharia Civil, Pontifícia Universidade Católica do Rio de Janeiro.

A certificação Passivhaus de construção se estabelece como uma das principais certificações de eficiência energética alemã na arquitetura. Seu potencial não foi reconhecido somente na Alemanha, mas sim em toda a Europa. Sua metodologia de avaliação leva em consideração a arquitetura passiva da edificação, resultando em uma menor demanda energética para climatização do ambiente. Por se tratar de uma certificação voluntária, desenvolvida para países frios, surgiu a questão de aplicá-la em países de climas quentes, fazendo uso do resfriamento por absorção, resfriamento esse pouco utilizado atualmente devido ao seu baixo rendimento. Os resultados obtidos nesse trabalho comprovam a redução da carga térmica do ambiente através da arquitetura passiva, auxiliada pelo resfriamento por absorção, utilizando a energia solar. Representa avanços na redução do consumo de energia das edificações de forma passiva e por energias renováveis.

\section{Palavras-chave}

Passivhaus; resfriamento por absorção; construções sustentáveis; condições de conforto. 


\section{Extended Abstract}

Tavares, Thiago Cavalheiro; Oliveira, Antônio Roberto Martins Barboza de (Advisor). Adaptation of the Passivhaus Building Model in Warm Climates. Rio de Janeiro, 2016. 133p. MSc. Dissertation - Departamento de Engenharia Civil, Pontifícia Universidade Católica do Rio de Janeiro.

\section{Introduction}

The Passivhaus certification is established as one of the leading German energy efficiency certifications in architecture. Its potential was not only recognized in Germany, but across Europe. Its method of evaluation takes into account the passive architecture of the building, resulting in a lower energy demand for ambient conditioning. Since it is a voluntary certification developed for cold countries, it raises the question of its effectiveness when it is applied in countries with hot climates, making use of absorption cooling, which is underused today because of its low efficiency. The results of this work demonstrates that there is a reduction of the thermal load of the environment through passive architecture, aided by absorption cooling using solar energy. It represents progress in reducing the energy consumption of buildings by introducing passive cooling coupled with renewable energy sources.

\section{The Passivhaus and their certification}

The term Passivhaus refers to a certification focused on the energy efficiency of a building. When the proper building reaches certain quantitative parameters of thermal energy, following specific standards, it receives the Passivhaus energy efficiency certification. Thus, it provides the scope of work for energy efficient buildings.

The certification was developed in the late 1980's by Wolfgang Feist, current director of the Passivhaus Institute (PHI), and Bo Adason. The creators realized that it was possible to maintain the internal thermal comfort of a building in the winter with controlled ventilation and heat recovery system. Thus, Passivhaus 
buildings are more energy efficient when compared to another residence with the same specifications, but under a conventional heating system (PHI, 2015).

The main objective of the rules used in the Passivhaus projects is to drastically reduce the use of equipment for heating and cooling, obtaining an energy balance and thermal comfort by passive components of the architecture, proven by their standardization. This objective is achieved with efficient heat sealing techniques, air tightness and a controlled ventilation system, functioning as the "lung of the building". It is essential to emphasize its basic principle, which derives from the production of energy efficient buildings to variable costs.

\section{Passive architecture to the Passivhaus}

The passive performance of a building can be understood as the energy used to supply the heating and cooling demand for the internal environment. MASCARÓ (1991) describes that passive performance can be assessed according to the energy components listed below:

- Losses through the heat seals: energy flows between the exterior and the interior of the building, resulting from conduction, convection and heat radiation;

- Losses by ventilation through the heat seals: energy flows resulting from the pressure difference in the air between the internal and external environment;

- Gains caused by solar radiation: energy flows arising from the difference between the surface temperatures of the seals and the external environment;

- Gains caused by internal heat production: the resulting heat output emitted by electronic appliances, lighting and heat generation by the human body itself.

Previously reported energy components are directly influenced by the passive features of the building, including: 
- Solar orientation;

- $\quad$ Compactness of the building;

- Solar protection;

- $\quad$ Air tightness;

- Ventilation system;

- Performance of the opaque thermal materials.

The name Passivhaus stands for the development of passive architecture, using building materials and modifications in construction arrangements to reduce the energy consumption. The advance of passive architecture by standardizing methods and criteria to be followed promotes the developing of more efficient buildings.

Table A below has been prepared in order to demonstrate Passivhaus solutions to standard criteria of passive architecture, therefore, circumventing passive architecture limitations.

Table A - Passivhaus solution for passive architecture

\begin{tabular}{ccc}
$\begin{array}{c}\text { Conventional passive } \\
\text { architecture } \\
\text { Criteria }\end{array}$ & $->$ & Passivhaus Architecture \\
\hline Solar orientation & $->$ & $\begin{array}{c}\text { Solutions } \\
\text { Enables a larger area on facades where the } \\
\text { energy balance would be inefficient }\end{array}$ \\
\hline Wind impact & $->$ & $\begin{array}{c}\text { Hermetical sealing buildings } \\
\text { Prevents the air flow through the opaque seals }\end{array}$ \\
\hline Shading & $->$ & $\begin{array}{c}\text { Shading use (fixed or mobile) } \\
\text { Reduces the radiation incidence inside the } \\
\text { building }\end{array}$ \\
\hline Solar reflectance & $->$ & $\begin{array}{c}\text { Use of efficient building materials } \\
\text { Disability in absorbing / reflecting sunlight on } \\
\text { the building }\end{array}$ \\
\hline Humidity & & $\begin{array}{c}\text { Controlled ventilation system } \\
\text { Control the flow of moisture and air entering } \\
\text { in the building }\end{array}$ \\
\hline
\end{tabular}

To achieve certification, all projects must be compiled using the Passive House Planning Package program (PHPP). The PHPP, a tool used to design buildings, consists of a development program within an Office Spreadsheet, where thermodynamic simulations are performed using imputed values. Surface areas, weather conditions, ventilation systems, shading, windows, cooling demand and heating demand are all part of the tool. 
For a building to reach the Passivhaus certification, it must meet certain established criteria for thermal comfort. Table B below has been prepared in order to summarize the main direct and indirect criteria for this certification.

Table B - Summary of criteria for certification suitable in hot climates.

\begin{tabular}{c|c}
\hline \multicolumn{2}{c}{ Direct criteria } \\
\hline $\begin{array}{c}\text { Annual consumption of primary energy } \\
\text { Annual energy demand for heating / cooling }\end{array}$ & $120 \mathrm{kwh} / \mathrm{m}^{2}$.year \\
\hline \multicolumn{2}{c}{ Indirect criteria } \\
$\mathrm{V}=$ Total Volume of the building
\end{tabular}

Source: PHI, 2015 (Adapted)

\section{Absorption cooling system}

The double-flow controlled ventilation system with heat recovery, regarded as the lung of Passivhaus buildings, is used as a rule in most of the buildings in Central Europe (PASSIVHAUS TRUST, 2014). The building, thus, is passively heated by recovering the heat generated in its interior, and its dissipation is prevent to the outside environment via the building's structures.

For its adaptability to hot and humid tropical climates, the building should follow the opposite strategy, being able to remove the heat accumulated inside.

In order to use cooling systems in sustainable ways and reduce the electric consumption of a building, a cooling technology was studied using solar panels. Absorption cooling technology was assessed to integrate into the cooling system.

Absorption cooling operation is made through differential pressures between its compartments, operating at higher pressures in the generator and condenser, and lower pressures in the absorber and evaporator. The heat introduced into the system enables the separation of the refrigerant (water) and the absorbent fluid (lithium bromide) which are attracted physically and chemically, resulting in increased refrigerant pressure and a procedure analogous to the electric compression system (Yasaki, 2007). 
Due to the continuous technological development of solar thermal collectors, the absorption cooling equipment was connected to be powered by the solar panels. This system was made possible thanks to the continuous advancement of the efficiency of solar collectors in the conversion of solar energy into heat. Other energy sources, such as kerosene or natural gas, can also be used as a second option if there is no thermal energy from the sun enough for supplying the cooling system.

\section{Study Case}

The research methodology used in the study has an exploratory nature, aiming to analyse the Passivhaus criteria and methodologies used in cold climates by adapting them to warm climates. Another exploratory factor was the study of the absorption cooling systems supplied by thermal energy, technology that was previously used in Brazil.

The research has a single case study as validation for the Passivhaus methodology. The city of Rio de Janeiro (weather station in Jardim Botânico) was chosen for the location of the study because of its high temperatures and high humidity throughout the year. Thus, it justified the use of passive architecture, aided by absorption cooling, for cooling the internal environment during periods of peaks in external temperatures.

We used the Meteonorm program to produce weather information data from the period of 1991 to 2010 .

Aiming to demonstrate the PHPP calculation tool and reduce the thermal load of a building using the criteria adopted by Passivhaus, certain characteristics of the building were set in the case study examined. These initial characteristics (number of inhabitants, the total floor area, thermal transmittance of construction elements, etc.), served as a comparative basis for the architectural change proposed by Passivhaus. A 3D modeling program was used to display the initial building.

After being set, the initial parameters of the building and meteorological site data were collected, the three-dimensional modeling of the building was developed and it is thermodynamic equilibrium was calculated through the PHPP pro- 
gram. The program generated results of the total energy demand per month to be removed, therefore aiming to reach Passivhaus certification.

The data of the initial thermal load over different months from the building are described in table $\mathrm{C}$.

Table C - Output results of the Passive House Planning Package program

\begin{tabular}{|c|c|c|c|c|}
\hline Mouths & $\begin{array}{l}\text { Energy demand } \\
\text { for latent heat } \\
\quad\left(\mathrm{kwh} / \mathrm{m}^{2}\right)\end{array}$ & $\begin{array}{c}\text { Energy demand } \\
\text { for sensible heat } \\
\left(\mathrm{kwh} / \mathrm{m}^{2}\right)\end{array}$ & $\begin{array}{c}\text { Sensible fraction } \\
(\%)\end{array}$ & $\begin{array}{c}\text { Total energy } \\
\text { demand } \\
\left(\mathrm{kwh} / \mathrm{m}^{2}\right)\end{array}$ \\
\hline January & 3.2 & 11.9 & 79 & 15.3 \\
\hline February & 3.4 & 11.9 & 78 & 15.5 \\
\hline March & 3.2 & 11.5 & 78 & 14.6 \\
\hline April & 2.8 & 8.1 & 74 & 10.5 \\
\hline May & 1.6 & 3.5 & 69 & 2.4 \\
\hline June & 1.3 & 0.6 & 29 & 1.6 \\
\hline July & 0.9 & 0.5 & 36 & 1.1 \\
\hline August & 1.0 & 1.1 & 52 & 1.4 \\
\hline September & 1.3 & 0.7 & 34 & 1.6 \\
\hline October & 2.0 & 4.8 & 71 & 5.8 \\
\hline November & 2.4 & 7.0 & 74 & 8.8 \\
\hline December & 2.9 & 10.0 & 77 & 12.7 \\
\hline Yearly & 26.1 & 71.5 & 73 & 97.6 \\
\hline \multicolumn{3}{|c|}{ Frequency of overheating } & \multicolumn{2}{|c|}{$63 \%$} \\
\hline \multicolumn{3}{|c|}{ Moisture frequency above the limit } & \multicolumn{2}{|c|}{$100 \%$} \\
\hline
\end{tabular}

Source: PHPP (Modified), 2015

With the results, changes in the architectural shapes of the building and in the constructive elements were made in order to reduce the total thermal load inside. This cycle was repeated until the point where architectural changes and constructive elements were ineffective in reducing the accumulated thermal energy inside.

The following table D shows the results of the building that got the best energy performance through the simulations using the PHPP.

It was noted in Table $\mathrm{D}$ a reduction of the total heat load of the building in $50.3 \%$, compared to the original building model (Table C), validating the PHPP program for the calculation of energy efficient buildings in hot climates. Despite the reduction of the accumulated heat load in the building, it still presents higher values in comparison to what is needed to achieve Passivhaus certification $(\leq 15$ $\mathrm{kwh} / \mathrm{m}^{2}$.year). 
Table D- PHPP final results of the annual energy demand

\begin{tabular}{|c|c|c|c|c|}
\hline Mouths & $\begin{array}{c}\text { Energy demand } \\
\text { for latent heat } \\
\left(\mathrm{kwh} / \mathrm{m}^{2}\right)\end{array}$ & $\begin{array}{c}\text { Energy demand } \\
\text { for sensible heat } \\
\left(\mathrm{kwh} / \mathrm{m}^{2}\right)\end{array}$ & $\begin{array}{c}\text { Sensible fraction } \\
(\%)\end{array}$ & $\begin{array}{c}\text { Total energy } \\
\text { demand } \\
\left(\mathrm{kwh} / \mathrm{m}^{2}\right)\end{array}$ \\
\hline January & 3.1 & 3.6 & 54 & 6.7 \\
\hline February & 3.2 & 3.7 & 53 & 6.9 \\
\hline March & 3.0 & 3.4 & 53 & 6.4 \\
\hline April & 2.7 & 2.8 & 51 & 5.5 \\
\hline May & 1.5 & 1.4 & 47 & 2.9 \\
\hline June & 1.6 & 0.2 & 13 & 1.8 \\
\hline July & 1.0 & 0.0 & - & 1.0 \\
\hline August & 1.1 & 0.4 & 24 & 1.5 \\
\hline September & 1.5 & 0.2 & 13 & 1.7 \\
\hline October & 1.9 & 1.7 & 47 & 3.6 \\
\hline November & 2.3 & 2.3 & 50 & 4.6 \\
\hline December & 2.8 & 3.1 & 52 & 5.9 \\
\hline Yearly & 25.7 & 22.8 & 47 & 48.5 \\
\hline \multicolumn{3}{|c|}{ Frequency of overheating } & \multicolumn{2}{|c|}{$23 \%$} \\
\hline \multicolumn{3}{|c|}{ Moisture frequency above the limit } & \multicolumn{2}{|c|}{$32 \%$} \\
\hline
\end{tabular}

Source: PHPP (Modified), 2015

With the results in Table $\mathrm{D}$, the absorption cooling system could then be properly dimensioned. The number of solar collectors in series and in parallel was calculated to attend to the water flow and nominal thermal power of the chosen absorption refrigerator, totalling 30 solar collectors to achieve the required design flow.

After dimensioning the solar collectors, the energy coming from the sun that supplied the absorption cooling system was compared with the energy necessary for cooling the building. This data is shown in Table E.

Table E shows the overall efficiency of the absorption cooling system proposed to cool the internal environment of a Passivhaus building in Rio de Janeiro. The surplus energy produced by the solar panels was able to provide sufficient thermal energy for hot water supply to the building. 
Table E - Results of the building in cooling demand supplied by solar panels and the necessary energy to heat the water for domestic use.

\begin{tabular}{c|c|c|c|c}
\hline Mouths & $\begin{array}{c}\text { Required en- } \\
\text { ergy for cool- } \\
\text { ing } \\
\text { (kwh/day) }\end{array}$ & $\begin{array}{c}\text { Energy needed } \\
\text { to heat the } \\
\text { water for do- } \\
\text { mestic use } \\
\text { (kwh/day) }\end{array}$ & $\begin{array}{c}\text { Energy removed } \\
\text { through Absorp- } \\
\text { tion Chiller } \\
\text { (kwh/day) }\end{array}$ & $\begin{array}{c}\text { Power supply meets } \\
\text { the required demand } \\
\text { for cooling and hot } \\
\text { water consumption? }\end{array}$ \\
\hline January & 259.61 & 23.26 & 345.86 & Yes \\
\hline February & 295.71 & 23.26 & 332.14 & Yes \\
\hline March & 247.74 & 23.26 & 309.55 & Yes \\
\hline April & 220.0 & 23.26 & 240.89 & Yes \\
\hline May & 112.26 & 23.26 & 227.39 & Yes \\
\hline June & 72.0 & 23.26 & 189.55 & Yes \\
\hline July & 38.71 & 23.26 & 225.48 & Yes \\
\hline August & 58.06 & 23.26 & 240.76 & Yes \\
\hline September & 68.0 & 23.26 & 250.76 & Yes \\
\hline October & 139.35 & 23.26 & 288.53 & Yes \\
\hline November & 184.0 & 23.26 & 311.97 & Yes \\
\hline December & 228.39 & 23.26 & 332.48 & \\
\hline
\end{tabular}

\section{Conclusions}

The Passivhaus certification was initially developed for the Central European climate, which conventionally uses the thermal energy of the building to maintain comfortable conditions inside. The use of heat recovery systems has become essential for heating the interior of the buildings in this climate. For its adaptability to hot and humid tropical climates, the building should follow the opposite strategy, being able to remove the accumulated heat. Thus, it caught up with the design of an energy-efficient building, making use of the absorption cooling system fuelled by solar energy.

As a result of the use of architectural elements established by Passivhaus, the analysed building achieved a reduction of $50.3 \%$ of its thermal load compared to the initial model. This fact proves the efficiency of the certification to reduce energy consumption of the building.

The final building model that achieved the best energy performance, has an annual accumulated heating load of $48.5 \mathrm{kwh} / \mathrm{m}^{2}$, an amount significantly lower than the original model, however, higher than the criteria established for the 
Passivhaus certification. Thus, use of the absorption cooling system supplied by solar energy was made to adapt the building to the limits established in the criteria. This resulted in the total efficiency of the system to adapt the building, reaching the Passivhaus certification.

\section{Keywords}

Passivhaus; absorption cooling; sustainable constructions; comfort conditions. 


\section{Sumário}

1. Introdução

22

2. Normas de construção e certificações ambientais 27

2.1 As normas de construção convencionais 28

2.2 Certificações ambientais 29

2.3 A passivhaus e sua certificação 36

3. Arquitetura passiva 42

3.1 Critérios de projeto $\quad 42$

4. A edificação passivhaus 56

4.1 Considerações de sua arquitetura 56

4.2 Controle de fluxos de ar 69

4.3 Critérios para certificação adaptados para climas quentes 74

4.3.1 Critérios diretos $\quad 75$

$\begin{array}{ll}\text { 4.3.2 Critérios indiretos } & 76\end{array}$

4.4 Da arquitetura passiva à Passivhaus $\quad 77$

4.5 O programa Passive House Planning Package (PHPP) 78

5. Sistema de resfriamento por absorção 80

$\begin{array}{ll}5.1 \text { Origem } & 80\end{array}$

5.2 Ciclo de resfriamento por absorção utilizando BrLi 82

5.3 O uso da energia solar para o abastecimento do refrigerador por absorção $\quad 85$

6. Estudo de caso 89

6.1 Dados de projeto estabelecidos 92

6.2 Aquisição de dados meteorológicos 94

6.3 Modelagem arquitetônica inicial 98

6.4 Arquitetura proposta 100

6.5 Dados de imput utilizados 103 
6.6 Dados de output do programa 111

6.7 Sistema de resfriamento por absorção 115

6.8 Resultados 120

7. Conclusões 124

7.1 Considerações finais sobre o trabalho 124

$\begin{array}{ll}7.2 \text { Recomendações futuras } & 125\end{array}$

8. Referências bibliográficas 127 


\section{Lista de Tabelas}

Tabela 1 - Critérios diretos para certificação Passivhaus

Tabela 2 - Principais diferenças das certificações ambientais

existentes com a Passivhaus

Tabela 3 - Diversos fatores de sombra normalmente utilizados

em projeto

Tabela 4 - Valores de refletância dos diferentes materiais em análise

Tabela 5 - Resumo dos critérios para certificação adaptados para

climas quentes

77

Tabela 6 - Solução Passivhaus para a arquitetura passiva

Tabela 7 - Dados climáticos do município do Rio de Janeiro

Tabela 8 - Resultados de Output do programa Passive House

Planning Pachage

Tabela 9 - Input de transmissividade térmica no programa

105

Tabela 10 - Input das áreas da edificação

107

Tabela 11 - Input dos dados das janelas existentes

109

Tabela 12 - Resultados do programa sobre a demanda energética anual (Passivhaus)

Tabela 13 - Comparações realizadas através do programa PHPP

Tabela 14 - Propriedade nominal do coletor solar escolhido

Tabela 15 - Propriedade nominal do resfriador por absorção escolhido

Tabela 16 - Energia térmica convertida dos painéis solares por metro quadrado

Tabela 17 - Potência unitária do painel solar analisado

Tabela 18 - Resultado do atendimento dos painéis solares à demanda de resfriamento e ao aquecimento da água para uso doméstico, requeridas pela edificação

Tabela 19 - Resultados do programa PHPP com o uso do resfriamento por absorção 


\section{Lista de Figuras}

Figura 1 - Construção "Canolfan Hyddgein", feita pela PWJ

Constructions

40

Figura 2 - Incidência solar sobre a fachada de uma edificação 44

Figura 3 - Carta solar do hemisfério norte na latitude 50 (Alemanha) $\quad 46$

Figura 4 - Carta Solar do hemisfério sul na latitude 22.83

(Rio de Janeiro).

Figura 5 - Janela com folha tripla de vidro, fazendo uso de gases

nobres para sua baixa transmissividade térmica

Figura 6 - Ventilação com fluxo cruzado, retirando o calor do

ambiente interno

Figura 7 - Exemplo onde um mesmo volume pode apresentar compacidades diferentes

Figura 8 - Transmissividade térmica de diferentes alvenarias segundo NBR15220

Figura 9 - Defasagem e amortecimento da onda térmica.

Figura 10 - Zonas onde são encontradas comumente pontes térmicas

Figura 11 - Demanda energética para o resfriamento da edificação conforme o uso de diferentes tipos de janelas

Figura 12 - Teste Blower door

Figura 13 - Sistema de recuperação de calor Passivhaus.

Figura 14 - Residência Passivhaus analisada pelo programa

Passive House Planning Package

Figura 15 - Geladeira por ciclo de absorção alimentada por querosene

Figura 16 - Sistema de resfriamento por absorção utilizando

Brometo de Lítio

Figura 17 - Coletores concentradores 86

Figura 18 - Coletores não concentradores planos $\quad 87$

Figura 19 - Sistema de resfriamento por absorção alimentado 
Figura 20 - Fluxograma da metodologia utilizada

Figura 21 Balanço de radiação solar nas diferentes orientações ao longo dos meses (média mensal)

Figura 22 - Balanço de temperatura atmosférica, ponto de orvalho e umidade relativa ao longo dos meses (média mensal)

Figura 23 - Diferença no posicionamento solar da fachada norte no período de inverno e verão

Figura 24 - Vista em perspectiva. 98

Figura 25 - Planta baixa da edificação 99

Figura 26- Fachadas norte/oeste do modelo físico da edificação

Passivhaus

Figura 27- Fachada sul/leste do modelo físico da edificação

Passivhaus

Figura 28 - Planta baixa (modelo de edificação com o melhor desempenho energético)

Figura 29 - Resultados do programa PHPP 114

Figura 30 - ThermoPower - VHP $30 \quad 115$

Figura 31 - Sistema Yasaki de resfriamento por absorção 116

Figura 32 - Painéis solares termais e sistema de resfriamento por absorção introduzidos na residência 


\section{Lista de Abreviaturas, Siglas e Símbolos}

IPCC Intergovernmental Panel on Climate Change

ICB International Council for Building

PHPP Passive House Planning Package

ABNT Associação Brasileira de Normas Técnicas

ISO International Organization for Standardization

WGBC World Green Building Council

IISBE International Initiative for a Sustainable Built Environment

SBA Sustainable Building Alliance

CONAMA Conselho Nacional do Meio Ambiente

BREEAM Building Research Establishment's Environmental Assess-

ment Method

LEED Leadership in Energy and Environmental Design

DGNG Sociedade Alemã de Construção Sustentável

AQUA Alta Qualidade Ambiental

USGBC United States Green Building Council

GBC Green Building Council

BRE Building Research Establishment

SBA Sustainable Building Alliance

CS Coeficiente de Sombreamento

CRRC Cool Roof Rating Council

SHGC Solar Heat Gain Coefficient

LBNL Lawrence Berkeley National Laboratory

HERV Heat and energy recovery ventilation

COP Coeficiente de Performance 


\section{1. \\ Introdução}

Segundo MASCARÓ (1991), a arquitetura passiva ${ }^{1}$, o tipo de construção que se adapta às condições do meio ambiente, e que era adotada na arquitetura vernacular, procura aproveitar os recursos e os materiais encontrados no próprio local aonde é construída.

Foi, ao longo do tempo, não sendo mais aplicada nos diferentes estilos de arquitetura que se seguiram, como o Egípcio, Grego, Romano, Bizantino, Gótico, Barroco, etc., que desembocaram no Modernismo do século XX, quando a forma segue a função.

Em 1973 com a crise do petróleo, o mundo volta seus olhos para métodos mais sustentáveis e ecológicos para as edificações, realizando pesquisas e ampliando suas geratrizes de fontes de energia renováveis (CORBELLA \& YANNAS, 2003). O estímulo à utilização de outros meios geradores de energia deve-se à necessidade de se desvincular da dependência dos combustíveis fósseis, pois além da questão econômica, busca-se a substituição de tal recurso não renovável e contaminante, como principal matriz energética.

$\mathrm{Na}$ atualidade, há uma grande inquietação do mundo quanto às mudanças climáticas. Sua origem data do quarto relatório do Painel Intergovernamental sobre Mudanças Climáticas (IPCC, 2007). Os resultados mostram um cenário alarmante para 2100 , com um aumento médio global de temperatura entre $1,8{ }^{\circ} \mathrm{C}$ e $4,0^{\circ} \mathrm{C}$. Esse aumento pode ser ainda maior $\left(6,4^{\circ} \mathrm{C}\right)$ se a população e a economia continuarem a crescer desenfreadamente e o consumo intenso de combustíveis fósseis for mantido. O quarto relatório de 2007 do IPCC aponta também com 90\% de confiabilidade que a maior parte do aumento de temperatura observado nos últimos 50 anos foi provocada por atividades antrópicas, pelas emissões de dióxido de carbono. Além do $\mathrm{CO}_{2}$, na listagem de gases contribuintes para o efeito estufa se encontram o óxido nitroso $\left(\mathrm{N}_{2} \mathrm{O}\right)$ e o metano $\left(\mathrm{CH}_{4}\right)$.

\footnotetext{
${ }^{1}$ Arquitetura que faz uso dos recursos existentes em seu local para promover o conforto térmico dos habitantes da edificação. Sinônimo da arquitetura bioclimática.
} 
Nesse importante contexto global de mudanças climáticas, destaca-se o setor da construção civil e sua responsabilidade quanto à sustentabilidade energética mundial. Segundo um estudo promovido pelo International Council for Building (ICB, 2005), a construção, manutenção e o uso das edificações na União Européia correspondem a $40 \%$ de seu consumo energético. Ainda segundo o ICB (2005), o resíduo da construção civil gera $40 \%$ do lixo produzido pelo homem. Comparando com os dados do IPCC (2007), onde um terço (1/3) da produção mundial de $\mathrm{CO}_{2}$, principal indicador de mudanças climáticas globais, tem origem no setor da construção civil, podemos destacar que boa parte da produção de gases nocivos à saúde, causadores do efeito estufa, são gerados na construção, manutenção e uso das edificações.

No setor da construção civil, o consumo energético no período de uso e manutenção da edificação é o principal gerador de poluentes (MOTTA \& AGUIAR, 2009). O gasto energético com aquecimento de água, climatização do ambiente e iluminação de uma residência ou espaço comercial é maior do que o gasto energético desprendido da extração da matéria prima do material construtivo e de sua fabricação.

Devemos relembrar os métodos de arquitetura passiva e seu conceito, já que possui uma importância considerável na economia de energia nas construções diante do panorama inquietante descrito.

Segundo a ABNT (2009), uma normatização é o processo de formulação e aplicação para regras para a solução ou prevenção de problemas. Uma certificação pode ser entendida como um processo no qual uma entidade de $3^{\mathrm{a}}$ parte avalia se determinado produto atende a norma técnica.

A Passivhaus, certificação de eficiência energética alemã, possui uma normativa própria, que, sendo seguida, resultam na certificação do empreendimento perante o Passive House Institute (PHI). A mesma utiliza critérios da arquitetura passiva, aliada a tecnologias de construção atuais, reduzindo a demanda energética para a climatização/calefação do espaço interno de uma edificação. A redução do consumo energético, associado à alta qualidade de conforto térmico, são seus objetivos principais.

Diferente de outras certificações ambientais, edificações que procuram atender sua normativa para atingir a certificação devem possuir critérios energéti- 
cos mínimos, sendo esses conferidos por uma ferramenta de cálculo apropriada, o Passive House Planning Package (PHPP), desenvolvido para esse fim.

A certificação foi voltada inicialmente para reduzir os gastos energéticos quanto aos sistemas de calefação em edificações localizadas em climas frios, auxiliando a manutenção de altos níveis de conforto interno. Visando a utilização do calor gerado no interior da edificação, o recuperador de calor presente nas edificações gera um conforto térmico de forma passiva.

Nesse trabalho buscou-se justificar o uso da Passivhaus em climas quentes, objetivando os mesmos resultados das edificações construídas em climas frios. A estratégia adotada para tal foi a adaptação do sistema de recuperação de calor para o resfriamento do ambiente interno. O recuperador de calor presente na grande maioria das edificações européias não se mostrou adequado para edificações em climas quentes, onde há a necessidade da retirada da energia térmica do ambiente.

O sistema de resfriamento por absorção, que antecede ao sistema de resfriamento por compressão, pode ser um importante instrumento para melhorar a qualidade do conforto interno das edificações e reduzir seu consumo energético. O sistema de resfriamento por absorção, alimentado por painéis solares termais, torna-se uma ferramenta para edificações manterem suas condições de conforto térmico.

O desenvolvimento deste trabalho contribui de forma a expandir o conhecimento na área de climatização natural das edificações utilizando técnicas passivas da arquitetura, além de introduzir o resfriamento por absorção movido a energia solar para locais de clima quente.

\section{Objetivo geral}

Introduzir e adaptar a metodologia Passivhaus para climas quentes, utilizando a energia solar para complementar seus ganhos quanto à eficiência no consumo de energia da edificação. 


\section{Objetivos específicos}

Sistematizar o referencial teórico que sustenta a introdução da metodologia em ambientes quentes; descrever as principais certificações ambientais existentes no mercado; elucidar as técnicas convencionais da arquitetura passiva, adequando as edificações às condições climáticas vigentes no local; descrever a Passivhaus e sua metodologia; assimilar e introduzir o sistema de resfriamento por absorção no estudo de caso, comprovando sua utilidade na climatização do ambiente; aplicação do programa PHPP para o cálculo da carga térmica na edificação analisada.

\section{Organização do Trabalho}

Essa dissertação foi dividida em oito capítulos.

O primeiro capítulo apresenta uma breve introdução sobre a importância da arquitetura passiva no mundo, dado o grande impacto do setor da construção civil no consumo energético mundial. A importância do trabalho, assim como seus objetivos gerais e específicos.

O capítulo 2 descreve as normas e certificações ambientais existentes no mercado. Uma comparação entra a Passivhaus e as demais certificações foi realizada.

No capítulo 3 há uma revisão dos elementos considerados na arquitetura passiva, com ilustrações. Os conceitos descritos da arquitetura passiva traduzem técnicas utilizadas na arquitetura vernacular para a adequação das condições térmicas internas da residência com relação ao clima externo.

O capítulo 4 apresenta o ponto de vista da certificação Passivhaus sobre a arquitetura passiva. Seus conceitos de arquitetura foram descritos, assim como seus critérios diretos e indiretos para certificação.

O capítulo 5 descreve o funcionamento do sistema de resfriamento e uma breve introdução aos coletores solares termais existentes no mercado. A proposta de integração do sistema de resfriamento com a arquitetura em análise, utilizando painéis solares, foi elaborada. 
No capítulo 6 foi realizado o estudo de caso proposto de uma edificação Passivhaus localizada no município do Rio de Janeiro. O sistema de resfriamento por absorção abastecido por painéis solares foi introduzido na edificação, adequando a residência aos seus critérios de certificação.

O capítulo 7 apresenta os principais resultados do trabalho, trazendo sugestões de pesquisa no ramo energético das edificações.

O capítulo 8 traz o referencial bibliográfico para a realização deste trabalho. 


\section{2. Normas de construção e certificações ambientais}

Para analisarmos as tendências atuais de construção sustentável, devemos inicialmente nos remeter ao conceito de sustentabilidade. O termo "sustentabilidade" surgiu em 1987, no Relatório de Brundtland, elaborado pela Comissão Mundial sobre Meio Ambiente e Desenvolvimento, sob a presidência da primeiraministra norueguesa Gro Harlem Brundlland. O Desenvolvimento Sustentável, desta forma, define-se em "Suprir as necessidades da geração presente sem afetar a habilidade das gerações futuras de suprir as suas" (Brundtland,1987).

O mesmo pode ser entendido como um conjunto de termos relevantes que, quando contabilizados, são importantes para a manutenção da vida futura em nossa sociedade. Em 2002, a Cúpula Mundial sobre o Desenvolvimento Sustentável (Conferência Rio+10) definiu os pilares da "sustentabilidade", além das estratégias para o desenvolvimento sustentável e seu progresso. A sustentabilidade, baseia-se em três pilares básicos (LASSU-USP, 2008):

- A Sustentabilidade Ecológica: refere-se ao capital natural de um empreendimento ou sociedade. Assim, formas compensativas ou de amenizar determinado impacto ambiental devem ser elaboradas para manutenção da fauna e flora da região;

- A Sustentabilidade Econômica: define uma economia capaz de suportar um equilíbrio nas causas e efeitos em decisões de negócios realizadas no âmbito ambiental, garantindo a parcialidade quanto à exploração dos recursos naturais;

- A Sustentabilidade Social: refere-se ao capital humano de um empreendimento, comunidade ou sociedade. Desta forma, todos os seus integrantes devem estar em um processo participativo integrado para o seu constante desenvolvimento. A sustentabilidade social implica em uma convivência pacífica e harmônica entre os diferentes setores sociais de um ambiente. 
Os três pilares de sustentabilidade são de grande importância para o conceito íntegro do termo originado em 1987. As tendências atuais de construção e certificação do empreendimento devem implementar modelos de sustentabilidade em todas as instâncias de projeto. Assim, normas construtivas devem ser adaptadas ao meio ambiente onde elas se encontram, respeitando valores econômicos, sociais e ambientais particulares, resultando em novas normas de construção, mais sustentáveis.

Segundo WASSOUF (2014), as normas de construção convencionais são reflexos das técnicas construtivas e arquitetônicas vigentes em cada país. Pelo fato de os métodos construtivos estarem diretamente relacionados à economia local do empreendimento, a sustentabilidade da edificação apresenta características bastante simples e rudimentar.

Segundo o artigo $1^{\circ}$ da Resolução n. ${ }^{\circ}$ 001/86 do Conselho Nacional do Meio Ambiente (CONAMA), o impacto ambiental é "qualquer alteração das propriedades físicas, químicas e biológicas do meio ambiente, causada por qualquer forma de matéria ou energia resultante das atividades humanas"; em nosso caso, vinculada à construção, uso e demolição de um empreendimento.

As certificações ambientais, de uma maneira geral, são elaboradas para avaliar e quantificar diferentes aspectos de sustentabilidade durante todo o ciclo de vida de um empreendimento, além de mensurar impactos ambientais gerados em seu entorno (LIBRELOTTO, 2010).

\section{1}

\section{As normas de construção convencionais}

As normas de construção oficiais são de caráter voluntário e variam conforme as técnicas empregadas nos diversos países, sendo influenciadas quanto ao desenvolvimento econômico do país em questão. Desta forma estabelecem requisitos mínimos quanto a sustentabilidade do empreendimento. Normas mais brandas ou mais rigorosas variam conforme as orientações políticas e sociais de cada país (WASSOUF, 2014, p.10). No Brasil, a Associação Brasileira de Normas Técnicas (ABNT) é encarregada da elaboração das normas de edificação vigentes. 
Salienta-se que normas de construção convencionais não regulam as construções com baixa eficiência ou rendimento energético negativo, assim como não vetam a utilização de materiais pouco ecológicos ou nocivos para o meio ambiente: formaldeídos, policloreto de vinila (PVC), arseniato de cobre cromatado (CCA), isocianatos, usados ao longo de todo o ciclo de vida de uma construção (WASSOUF, 2014, p.10).

Destaca-se o esforço de muitos países da União Européia em implementar novas leis de melhoria da eficiência energética e do uso de energias renováveis na construção. Todos os países membros devem rever e atualizar suas normas de edificação a cada três anos, atualizando suas exigências energéticas para a construção (UNFCCC $\left.{ }^{2}, 2015\right)$.

Em países latino-americanos, o tratamento dado às normas de edificação historicamente não possui um comprometimento quanto à constante atualização de suas normas vigentes para uma melhoria do desempenho das suas construções (CORBELLA \& YANNAS, 2003).

É característica, a falta de ênfase à redução do consumo elétrico específico, derivado de eletrodomésticos e da iluminação, em suas normas de edificação. O consumo de energia para alimentação de sistemas de resfriamento/calefação, comparado a países mais desenvolvidos (Canadá, Estados Unidos e na Europa) é, ainda, relativamente baixo, devido ao alto custo de se operacionalizar o sistema $\left(\right.$ IEA $\left.^{3}, 2006\right)$.

Nota-se que o funcionamento energético é precário em grande parte das edificações da América Latina. Há a necessidade de uma busca por maior eficiência energética das edificações, com uma melhoria no conforto térmico do ambiente.

\section{2 \\ Certificações ambientais}

Diante da abrangência do termo "sustentabilidade", a Organização Internacional de Padronização, um órgão independente e não governamental, vem desde 1947 desenvolvendo normas para a quantificação de índices de sustentabilidade

\footnotetext{
${ }^{2}$ United Nations Framework Convention on Climate Change

${ }^{3}$ International Energy Agency
} 
durante o ciclo de vida de uma construção, formando as normas ISO. Essas normas são mais complexas do que as normas de edificação locais vigentes em cada país, pois tentam englobar todos os aspectos de sustentabilidade.

A partir das normas ISO e com uma maior preocupação global da sociedade em relação à sustentabilidade, novas ferramentas que quantificam os índices de sustentabilidade no projeto, execução e uso da edificação vem sendo criadas. Essas ferramentas podem ser chamadas de "Sistemas de Qualificação e Certificação Ambiental".

Segundo WASSOUF (2014, pg.13), as certificações ambientais devem quantificar os impactos ambientais ao longo de seis etapas do ciclo de vida de um empreendimento:

- Planejamento Urbanístico: quantificam-se os impactos ambientais gerados pelas decisões urbanísticas (ex: as infraestruturas);

- Produto: quantificam-se os impactos ambientais gerados no processo de produção dos materiais de construção;

- Transporte de materiais: quantificam-se os impactos ambientais gerados pelo transporte de materiais de construção até o canteiro de obras;

- Construção: quantificam-se os impactos ambientais gerados durante a construção do empreendimento;

- Uso do edifício: quantificam-se os impactos ambientais gerados durante o uso do edifício. A parte mais importante dessa etapa é o consumo energético do edifício e a energia necessária para sua manutenção;

- $\quad$ Fim do ciclo de uso: quantificam-se os impactos ambientais gerados com a demolição da construção.

Dentro de cada etapa do ciclo de vida do empreendimento, as diferentes certificações ambientais determinam critérios mais relevantes de acordo com o clima e as condições sócio-econômicas do país analisado. Cada critério pode corresponder a um ou mais indicadores e impactos ambientais.

O impacto ambiental pode ser quantificado segundo um indicador ambiental específico (ex: dióxido de carbono equivalente a outros gases de efeito estufa). Em comum, todas as certificações ambientais tem a meta de aliar ferramentas da 
arquitetura e tecnologia para quantificar a sustentabilidade ao longo do ciclo de vida do empreendimento, projetando-o com o intuito de reduzir seus danos gerados à natureza e aos moradores/vizinhos. Algumas das principais certificações ambientais no mundo são:

BREEAM - BRE Environmental Assessment Method - Inglaterra

LEED - Leadership in Energy and Environmental Design - Estados Unidos/Brasil

DGNB - German Sustainable Building Concil - Alemanha

AQUA-HQE - Alta Qualidade Ambiental - França/Brasil

\section{BREEAM - Building Research Establishment Environmental As- sessment Method}

O BREEAM foi o primeiro método de avaliação de desempenho ambiental de edifícios, desenvolvido na Inglaterra em 1990 pelo Building Research Establishment (BRE), instituição inglesa responsável pela criação do selo. Muito popular no Reino Unido, o BREEAM possui 549.619 edifícios certificados e 2.250.672 em fase de certificação desde seu lançamento no mercado (BREEAM, 2016).

O BREEAM define as melhores práticas de sustentabilidade nas edificações, em seu processo de design, construção e operação. Desta forma, tornou-se um dos métodos mais abrangentes, e amplamente reconhecido, de desempenho ambiental de um edifício. A certificação encoraja os engenheiros, arquitetos e clientes a refletir sobre as baixas emissões de carbono e o baixo impacto ambiental do empreendimento em relação à sua vizinhança, minimizando a demanda de energia criada por um edifício, antes de considerar a introdução de tecnologias de eficiência energética e de redução da produção de gás carbônico.

Chegou ao Brasil através da Certificação Internacional Bespoke BREEAM, possuindo critérios específicos sobre as normas e regulamentações das edificações locais (BREEAM, 2016).

A avaliação de desempenho ambiental de uma edificação proposta pelo BREEAM, contém itens de atendimento obrigatório e outros classificatórios, re- 
conhecidos internacionalmente, aplicados a partir de uma ampla gama de categorias e critérios, abordando questões sobre o impacto do edifício no meio ambiente, saúde e conforto do usuário e gestão de recursos. O atendimento a todos os itens de caráter obrigatório e um número mínimo de itens classificatórios irá corresponder a classificação do empreendimento em um dos níveis de desempenho ambiental possíveis (COELHO, 2010).

Segundo o "Manual Técnico para Construção BREEAM NEW CONSTRUCTION SD5073-2.0:211", o referencial do desempenho ambiental de edificações localizadas fora da Europa pelo BREEAM Internacional Bespoke pode ser dividido em nove categorias:

- Gerenciamento;

- $\quad$ Saúde e bem-estar;

- $\quad$ Energia;

- Transporte;

- Água;

- Materiais;

- Resíduos;

- Uso do solo e Ecologia;

- Poluição.

As categorias são ponderadas e para cada categoria existem vários critérios determinados, denominados "créditos". Esses créditos devem ser elaborados pelo assessor certificado do BREEAM, de acordo com os dados do empreendimento em relação à sua sustentabilidade, nas diferentes categorias de análise. O empreendimento é avaliado pelo somatório de créditos em cada categoria e pela multiplicação do seu peso correspondente em questão. A pontuação mínima para garantir que um empreendimento consiga a certificação ambiental BREEAM equivale a 30 pontos. 


\section{LEED - Leadership in Energy and Environmental Design}

O LEED é um sistema de certificação ambiental americano desenvolvido pelo United States Green Building Council (USGBC), lançado no ano 2000 (USGBC, 2016)

O LEED possui atualmente 82.000 empreendimentos no mundo certificados e 278.500 em fase de certificação (USGBC, 2016). O Conselho de Edifícios Verdes do Brasil (GBC -Brasil) é uma organização não-governamental, encarregada de capacitar profissionais, na divulgação das melhores práticas na construção sustentável de acordo com as características brasileiras, além de disseminar o marketing da certificação LEED pelo país. Contudo, o GBC não é responsável pela certificação ambiental do empreendimento no país, que fica sob encargo da USGBC nos Estados Unidos.

Para a certificação ambiental LEED, o profissional consultor que analisará todo o planejamento e implantação do empreendimento deve ser cadastrado no sistema de profissionais do USGBC. O mesmo irá montar um processo detalhado do empreendimento em questão, que, após ser enviado ao USGBG, será avaliado, questionado, certificado, ou não, de acordo com diversas categorias.

Cada categoria em um sistema de classificação LEED é composta de prérequisitos e créditos. Os pré-requisitos são elementos necessários (ou estratégias de construção verde) que devem ser incluídos em qualquer projeto que deseja obter a certificação LEED. Os créditos são elementos opcionais, resumindo em estratégias o que os projetos podem optar para ganhar pontos em sua classificação ambiental LEED (USGBC, 2016).

Os critérios de avaliação LEED chamados de créditos, contemplam as seguintes categorias:

- $\quad$ Espaços Sustentáveis (Sustainable Sites -SS);

- $\quad$ Eficiência Hídrica (Water Efficiency-WE);

- $\quad$ Energia e Atmosfera (Energy \& Atmosphere - EA);

- $\quad$ Fontes e Materiais (Materials \& Resources - MR);

- $\quad$ Qualidade Ambiental Interna (Indoor Environmental Quality - EQ);

- $\quad$ Design e Inovação (Innovation \& Design Process - ID);

- $\quad$ Prioridades Regionais (Regional Priority - RP); 
O sistema de classificação LEED geralmente possui cem créditos básicos, distribuídos ao longo de suas diferentes categorias, mais seis créditos adicionais para Inovação e Design e quatro créditos adicionais para prioridades regionais. Algumas categorias possuem um número de créditos disponíveis maior do que outras, de acordo com o grau de impacto ambiental e os benefícios humanos que cada categoria propicia, segundo valores estabelecidos pelo LEED (USGBC, 2016).

\section{DGNB - German Sustainable Building Council}

O Conselho de Construção Sustentável da Alemanha (DGNB) foi criado em 2007. Em uma cooperação com o Ministério de Transportes, Construção e Desenvolvimento Urbano, o DGNB, em 2009, desenvolveu um método de avaliação da sustentabilidade de um edifício focado em uma visão integral de todo o ciclo de vida de uma edificação. Atualmente existem mais de 490 edificações certificadas (valor esse correspondente a $0,1 \%$ das edificações com a certificação BREEAM), e 400 projetos em fase de certificação em todo o mundo (DGNB, 2016).

O conceito de sustentabilidade no modelo de certificação ambiental alemão proposto pelo DGNB vai além do tripé da sustentabilidade, conhecido mundialmente. A certificação DGNB cobre todas as categorias de sustentabilidade de um edifício: ambiental; econômico; sócio-cultural e funcional; tecnológico; processo de qualidade e condições do local. Tais aspectos possuem pesos iguais no sistema de pontuação DGNB, dando importância igualitária a todos os aspectos de sustentabilidade do empreendimento.

Existem seis categorias do sistema DGNB, podendo ser classificadas da seguinte maneira (DGNB, 2016):

- $\quad$ Qualidade ecológica: 22,5\%;

- Qualidade econômica: 22,5 \%;

- Qualidade sócio-cultural e funcional: 22,5\%;

- $\quad$ Qualidade tecnológica: 22,5\%;

- $\quad$ Qualidade do processo: $10 \%$; 
- $\quad$ Qualidade da localização: - seu peso não faz parte da ponderação final.

Cada uma das seis categorias analisadas no sistema DGNB se subdividem em critérios adaptados para atender às condições locais, relevantes à certificação. Os critérios de cada categoria são listados junto com os seus indicadores, que são avaliados quantitativamente e qualitativamente. Cada critério tem um valor máximo de 10 pontos e, para assegurar a flexibilidade da avaliação do empreendimento, cada critério pode ser ponderado, em função de sua relevância, para cada tipo de edifício, de 0 a 3 (DGNB, 2016).

\section{AQUA-HQE - Alta Qualidade Ambiental}

A certificação Alta Qualidade Ambiental (AQUA-HQE) é uma certificação internacional, criada em 2008, desenvolvida a partir da certificação ambiental francesa Haute Qualité Environmentale (HQE), e aplicada, exclusivamente no Brasil, pela Fundação Vanzolini, adaptando suas normas, referências e parâmetros para as características das edificações brasileiras (FUNDAÇÃO VANZOLINI, 2014).

O HQE, criado em 1996, possui uma certificação ambiental conhecida mundialmente, com projetos nos diferentes continentes, como: Américas (Brasil e Estados Unidos), África, Oceania, Europa e Ásia, totalizando 380.000 projetos certificados pelo mundo (HQE, 2016).

Atualmente, a certificação AQUA-HQE possui alguns empreendimentos certificados pelo Brasil em diferentes fases de ante-projeto, projeto, execução e operação. Segundo a FUNDAÇÃO VENZOLINI (2014), são, ao todo, 146 empreendimentos na fase de ante-projeto; 72 na fase de projeto; 22 na fase de execução; 10 na fase de operação, mostrando um crescimento de novos empreendimentos interessados na adaptação do modelo de construção sustentável proposto pela AQUA-HQE. A certificação ambiental AQUA-HQE representa $31 \%$ das construções com certificação ambiental no Brasil, perdendo apenas para a certificação americana LEED, que corresponde a $38 \%$ das certificações ambientais brasileiras (IMED, 2014). 
O processo de certificação AQUA-HQE se subdivide em dois segmentos de análise de uma edificação: Sistema de Gestão do Empreendimento (SGE) e Qualidade Ambiental do Edifício (QAE).

Existem quatorze critérios na avaliação dos auditores da AQUA para a QAE, dividido em quatro grupos (sítio e construção, gestão, conforto e saúde), que verificam o desempenho arquitetônico e técnico do empreendimento (FUNDAÇÃO VANZOLINI, 2014).

O AQUA-HQE baseia-se em desempenho, não existindo pontuação. Cada categoria pode alcançar o desempenho classificado como: bom, superior ou excelente. Para receber a certificação ambiental AQUA-HQE, o empreendimento deve alcançar no mínimo três desempenhos excelentes e sete bons nas categorias.

\section{3}

\section{A Passivhaus e sua certificação}

O termo Passivhaus se refere a uma certificação ambiental, de caráter voluntário, focada na eficiência energética do empreendimento. Quando a devida edificação alcança determinados parâmetros quantitativos de energia térmica, seguindo normativas específicas, a mesma recebe a certificação de eficiência energética Passivhaus. Desta forma, ela fornece aos empreendimentos o escopo de trabalho para construções energeticamente eficientes.

As certificações ambientais, como descritas anteriormente, quantificam e classificam a sustentabilidade de um empreendimento em suas diferentes etapas do ciclo de vida, porém não descrevem processos determinados nem soluções concretas para atingir a um grau de padronização.

Poucas certificações ambientais são capazes de mensurar a arquitetura passiva da edificação, fazendo com que empreendimentos com má compatibilidade térmica ganhem certificações ambientais, por possuírem sistemas ativos de calefação ou climatização eficientes. Pelo fato da Passivhaus utilizar uma normatização de construção para receber a certificação, possui, assim, soluções concretas e procedimentos definidos para alcançar seus objetivos, além de medir quantitativamente a sustentabilidade do empreendimento. 
Enquanto as demais certificações ambientais tentam controlar, adotando diferentes critérios, o impacto ambiental causado pelo empreendimento ao longo do seu ciclo de vida, a metodologia de certificação Passivhaus de construção determina critérios bem definidos. Limitando o consumo e a demanda energética de um empreendimento, obtém-se como resultado a redução de seu impacto ambiental e custo do uso da edificação.

Segundo o PHI (2014), instituto criador do certificado, sua primeira construção foi datada de 1991, em Darmstadt, na Alemanha, que monitora a performance desta primeira residência desde então, junto com outras 250 edificações espalhadas pela Europa, demonstrando seu excelente desempenho energético. Atualmente o PHI possui mais de 25.000 edificações com a certificação Passivhaus de construção no continente europeu, dispondo de outros empreendimentos espalhados pelo Globo.

A certificação foi desenvolvida no final da década de 1980, por Wolfgang Feist, atual diretor do Passivhaus Institute, e por Bo Adason. Seus criadores perceberam que era possível manter o conforto térmico interno da edificação no inverno com uma ventilação controlada e um sistema de recuperação de calor. Desta forma, conseguiu-se uma economia de energia em comparação a uma mesma residência com um sistema de calefação convencional, sendo esta menos eficiente (PHI, 2015).

Com o passar do tempo, foi-se ampliando sua normativa utilizada para climas mais quentes, como o clima sub-tropical, sendo construídas edificações em vários países do sul da Europa, Japão, Coréia do Sul e Nova Zelândia (WASSOUF, 2014).

A normativa utilizada nos empreendimentos Passivhaus possui como objetivo principal a redução drástica do uso de equipamentos para calefação e refrigeração, obtendo um equilíbrio energético e um conforto térmico por componentes passivos da arquitetura, comprovados através de sua padronização numérica. Esse objetivo é alcançado com técnicas de vedação térmica eficientes, estanqueidade do ar e um sistema de ventilação controlado, funcionando como o pulmão da edificação.

Torna-se essencial ressaltar seu princípio básico, que deriva na produção de edificações sustentáveis energeticamente eficientes a custos variáveis.

Segundo WASSOUF (2014, p.15), a certificação possui três vertentes: 
- Requisitos energéticos mínimos. Estabelece uma série de requisitos energéticos mínimos que se baseiam, por exemplo, na limitação da demanda de energia para calefação e refrigeração, assim como do consumo de energia primária total;

- Conjunto de soluções. Oferece ao mercado da construção um conjunto de soluções concretas para alcançar esses requisitos mínimos; essas soluções costumam ser comprovadas em edificações-piloto antes de serem lançadas no mercado;

- $\quad$ Ferramenta de cálculo. A norma oferece certas ferramentas de cálculo para que o projeto desenvolvido cumpra com os requisitos estabelecidos de controle energético.

Sendo baseada na eficiência energética de uma construção, seus critérios de desempenho estabelecidos são bem específicos e rigorosos. Os mesmos devem ser atingidos para o empreendimento receber o certificado final. A Tabela 1 Tabela 1 - Critérios diretos para certificação Passivhausa descreve os critérios diretos para a certificação do empreendimento.

Tabela 1 - Critérios diretos para certificação Passivhaus

\begin{tabular}{l|l}
\hline Consumo Anual de Energia Primária & $\begin{array}{l}\text { O consumo anual total energético utilizado na } \\
\text { edificação (calefação + refrigeração + ilumina- } \\
\text { ção + eletrônicos etc.) é limitado a 120 } \\
\text { killowatts.hora/ por metro quadrado de área } \\
\text { tratada da mesma }\end{array}$ \\
\hline Demanda Anual de Aquecimento/Resfriamento & $\begin{array}{l}\text { Consumo máximo anual de 15 killowatts.hora/ } \\
\text { por metro quadrado de área tratada da residên- } \\
\text { cia }\end{array}$ \\
\hline Estanqueidade ao ar & $\begin{array}{l}\text { Volume limite de 0,6 trocas de ar por hora, } \\
\text { com um diferencial de pressão referente a 50 } \\
\text { Pascal entre o meio interno externo deve ser } \\
\text { aferido através de testes }\end{array}$ \\
\hline
\end{tabular}

Fonte: PASSIVE HOUSE INSTITURE, 2014

Para se alcançar os critérios estabelecidos, foi desenvolvida, uma metodologia a ser seguida. Quando projetada a edificação, seus autores devem reduzir ao máximo a carga térmica de calefação/climatização do ambiente através de medidas passivas, tais como: orientação solar, formatos arquitetônicos, uso de materi- 
ais isolantes, presença de recuperadores de calor, uso passivo da energia solar, sombreamento, eliminação de pontes térmicas, etc.

Devido a sua alta estanqueidade, um suprimento contínuo de ar filtrado deve ser encaminhado para o interior da edificação, sendo dela retirado o ar após ser circulado, via sistemas de exaustão. O recuperador de calor, acoplado ao sistema de controle de fluxo de ar, permite um balanço energético da edificação, garantindo uma alta qualidade de conforto interno para seus usuários.

A metodologia proposta para atingir os critérios definidos, assim como informações gerais do empreendimento a ser desenvolvido, devem ser aferidas através de uma ferramenta apropriada. O PHPP, ferramenta que permite ao usuário calcular o balanço térmico da edificação em análise (perdas e ganhos de calor) através de simulações, foi desenvolvida para esse fim (PHI, 2015).

Por possuir uma normativa própria para a certificação, além de metodologia padronizada de construção, com objetivos e processos bem definidos, não se pode compará-la a outras certificações ambientais internacionais, pois seus focos e objetivos são diferentes.

Enquanto a Passivhaus está voltada para a redução do consumo energético de uma edificação, as certificações ambientais estão focadas na redução das emissões de dióxido de carbono $\left(\mathrm{CO}_{2}\right)$, além de outros fatores que causam o impacto ambiental. Por possuírem objetivos diferentes, a normativa/certificação analisada e as certificações ambientais podem ser aplicadas a um mesmo empreendimento.

A Figura 1 mostra um projeto executado no País de Gales, que recebeu “excelente” pela classificação do certificado ambiental BREEAM, além de receber a certificação Passivhaus, sendo o primeiro empreendimento no Reino Unido a ser certificado pelo Passive Hause Institute (PASSIVHAUS TRUST, 2015). 


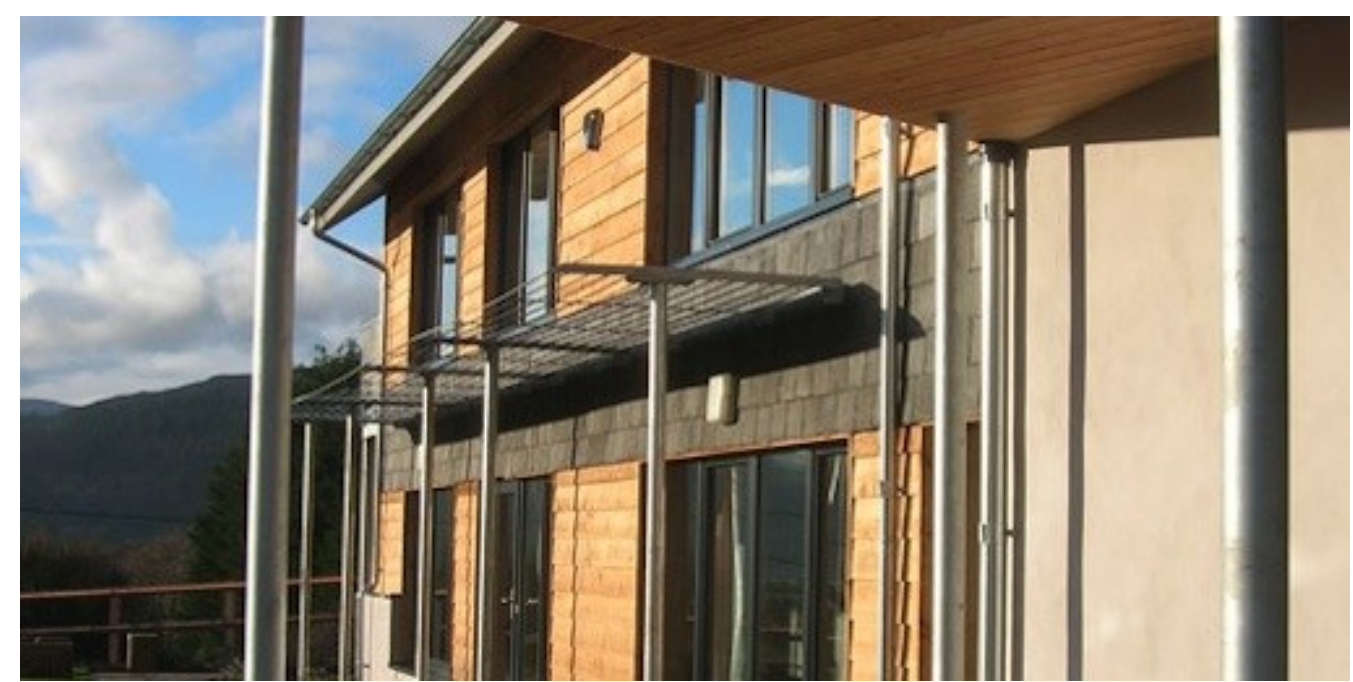

Figura 1 - Construção “Canolfan Hyddgein”, feita pela PWJ Constructions.

Fonte: http://sustainablereview.net/shortlist-announced-uk-passivhaus-awards-2013/, 2015

A Tabela 1, descreve de forma resumida e sucinta as principais diferenças entre as certificações ambientais internacionais, relatadas anteriormente, e a certificação Passivhaus. Apresenta, novamente, os diferentes objetivos propostos em cada certificação, de maneira a distinguir os requerimentos individuais das mesmas.

Diante da Tabela 2, conclui-se que a Passivhaus pode ser classificada como uma norma/certificação de construção energeticamente eficiente, pois ela padroniza metodologias para atingir a seus objetivos e critérios, fazendo uso de uma ferramenta para obter resultados.

Temos ainda a possibilidade de se integrar as diferentes certificações ambientais em análise com a normativa, agregando demais características e valores de sustentabilidade, como: redução da produção de resíduos, reutilização de água, uso de energias renováveis, construção com materiais sustentáveis etc.

Assim, acredita-se que a Passivhaus possa elevar o conceito de construções sustentáveis a um novo patamar, no qual as edificações possam ser padronizadas, adotando as características do ambiente local para seu melhor equilíbrio energético. 
Tabela 2 - Principais diferenças das certificações ambientais existentes com a Passivhaus

\begin{tabular}{|c|c|c|}
\hline Requerimentos & $\begin{array}{c}\text { Certificações Ambientais } \\
\text { Internacionais } \\
\end{array}$ & Passivhaus \\
\hline Natureza da certificação & $\begin{array}{l}\text { Quantificação da sustentabili- } \\
\text { dade do empreendimento }\end{array}$ & $\begin{array}{l}\text { Garantir o conforto térmico } \\
\text { interno da edificação com a } \\
\text { menor consumo energético }\end{array}$ \\
\hline $\begin{array}{l}\text { Demanda anual de energia } \\
\text { primária }\end{array}$ & $\mathrm{X}$ & $\leq 120 \mathrm{Kwh} / \mathrm{m}^{2}$ \\
\hline $\begin{array}{l}\text { Demanda energética anual } \\
\text { para aquecimento ou resfria- } \\
\text { mento da edificação }\end{array}$ & $\mathrm{X}$ & $\leq 15 \mathrm{Kwh} / \mathrm{m}^{2}$ \\
\hline Estanqueidade do ar & $\mathrm{X}$ & $\leq 0,6 / \mathrm{h}(\mathrm{n} 50)$ \\
\hline $\begin{array}{l}\text { Transmissividade térmica das } \\
\text { paredes e telhados }\end{array}$ & $\mathrm{X}$ & Baixa \\
\hline $\begin{array}{l}\text { Transmissividade térmica das } \\
\text { vedações semi-opacas }\end{array}$ & $\mathrm{X}$ & Baixa \\
\hline Metodologia de análise & $\begin{array}{l}\text { Gerenciamento do impacto } \\
\text { ambiental em diferentes seto- } \\
\text { res }\end{array}$ & Balanço de energia térmica \\
\hline Programação & 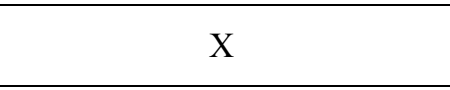 & $\begin{array}{lll}\text { Passive House Planning } \\
\text { Package }\end{array}$ \\
\hline Temperatura de conforto & $\begin{array}{l}\text { Não possuem uma padroniza- } \\
\text { ção }\end{array}$ & $\begin{array}{l}20{ }^{\circ} \mathrm{C} \text { no inverno e } 25{ }^{\circ} \mathrm{C} \text { no } \\
\text { verão. Seus limites não devem } \\
\text { ultrapassar frequências de } \\
10 \% \text { do tempo de uso da edi- } \\
\text { ficação ao longo do ano }\end{array}$ \\
\hline Produção de resíduos & $\begin{array}{l}\text { Gerenciamento na produção } \\
\text { de resíduos }\end{array}$ & $\mathrm{X}$ \\
\hline Uso do solo e ecologia & $\begin{array}{l}\text { Gerenciamento no uso e im- } \\
\text { pacto do solo }\end{array}$ & $\mathrm{X}$ \\
\hline $\begin{array}{l}\text { Transporte e coleta de materi- } \\
\text { ais }\end{array}$ & $\begin{array}{l}\text { Gerenciamento do transporte e } \\
\text { coleta de materiais da edifica- } \\
\text { ção }\end{array}$ & $\mathrm{X}$ \\
\hline Materiais sustentáveis & $\begin{array}{l}\text { Uso de materiais sustentáveis } \\
\text { reduzindo o impacto ambien- } \\
\text { tal }\end{array}$ & $\mathrm{X}$ \\
\hline $\begin{array}{l}\text { Integração com as demais } \\
\text { certificações }\end{array}$ & $\mathrm{X}$ & $\begin{array}{l}\text { Pode ser integrada com as } \\
\text { diferentes certificações ambi- } \\
\text { entais }\end{array}$ \\
\hline
\end{tabular}




\section{3. Arquitetura passiva}

\section{1}

\section{Critérios de projeto}

Segundo a Sustainable Building Alliance, o maior gasto energético durante todo o ciclo de vida de uma edificação é em sua fase de uso. Durante essa fase, os critérios mais relevantes para o consumo energético de um empreendimento são (SBA, 2014):

- Consumo de energia para refrigeração ou calefação do ambiente interno;

- Consumo de energia elétrica (aparelhos eletrônicos);

- Consumo de energia para o aquecimento da água;

- $\quad$ Consumo de água potável.

Tal consumo pode ser prejudicial ao meio ambiente, diminuindo os seus recursos renováveis, aumentando a geração de gases nocivos, além de provocar a deteriorização das condições de qualidade e higiene em um ambiente interno. Ainda segundo a SBA (2014), o consumo de energia para calefação e refrigeração do ambiente apresenta o maior impacto ecológico entre eles.

Segundo WASSOUF (2014), países do Mediterrâneo, curiosamente, possuem um consumo de energia para calefação ou refrigeração de um edifício maior ou semelhante a países do centro-europeu. Essa característica demonstra o grande potencial para redução e economia energética nas edificações de países de clima quente e úmido, pois o processo de eficiência energética ainda não está consolidado e integrado no ciclo de vida da edificação.

O consumo energético para a climatização interna de um empreendimento depende de seu desempenho passivo e da eficiência dos sistemas ativos de refrigeração ou calefação. Com o posicionamento inadequado do edifício perante a inci- 
dência solar e o movimento dos ventos, maior será seu consumo energético para o conforto térmico; quanto menor a eficiência dos sistemas passivos de climatização, maior será a energia consumida para alimentá-los.

O desempenho passivo de uma edificação pode ser entendido como a energia empregada para suprir a demanda de calefação ou refrigeração de um ambiente. MASCARÓ (1991) descreve que o desempenho passivo pode ser avaliado segundo os componentes energéticos listados a seguir

- Perdas através das vedações térmicas: fluxos energéticos entre o exterior e o interior do edifício decorrentes da condução, convecção e radiação do calor;

- Perdas por ventilação através das vedações térmicas: fluxos energéticos decorrentes da diferença de pressão no ar entre o ambiente interno e externo;

- Ganhos ocasionados pela radiação solar: fluxos energéticos decorrentes da diferença entre as temperaturas superficial das vedações e o ambiente externo, além dos ganhos de radiação direta e indireta;

- Ganhos ocasionados pela produção de calor interno: decorrentes da produção de calor emitidos por aparelhos eletrônicos, iluminações e a geração de calor pelo próprio corpo humano.

Os componentes energéticos relatados anteriormente são influenciados diretamente pelas características passivas do edifício, entre elas:

- $\quad$ Orientação Solar;

- Compacidade;

- Proteção Solar;

- $\quad$ Estanqueidade do ar;

- $\quad$ Sistema de ventilação;

- Desempenho das vedações térmicas opacas;

- Desempenho das vedações térmicas transparentes. 
A seguir iremos relatar os principais critérios utilizados pela arquitetura passiva para atender ao conforto climático de um ambiente interno, durante a maior parte do ano de uma edificação contemporânea.

Esses critérios passivos são baseados em conhecimentos milenares, onde o homem observou o ambiente em que vive e baseou-se em causas e consequências na mudança das condições climáticas de seu ambiente externo, quanto ao impacto na qualidade do conforto térmico de sua moradia.

A Passivhaus irá utilizar os mesmos critérios passivos da arquitetura vernacular, padronizando e quantificando suas características, porém as estratégias e técnicas construtivas a serem empregadas serão diferentes das adotadas por esse tipo de arquitetura, dando uma interpretação mais moderna e adequada aos padrões atuais de vida, conforto e métodos de construção.

\section{Orientação Solar}

A orientação solar de uma edificação é um fator que afeta diretamente sua demanda energética para a climatização/calefação interna. $\mathrm{O}$ impacto da radiação solar direta e do fluxo de ar sobre as vedações externas da edificação, influenciam em uma rápida variação de temperatura interna da mesma. Desta forma, há uma dependência sobre a transmissividade térmica dos materiais constituintes das vedações da edificação para que não ocorra uma brusca perda/ganho de calor.

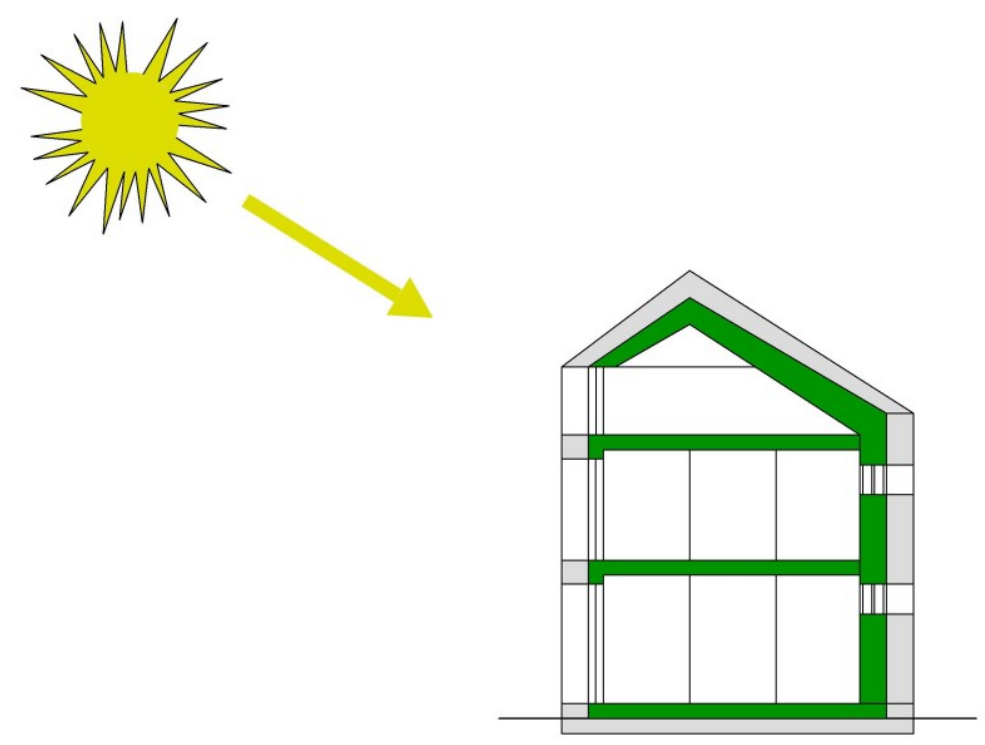

Figura 2 - Incidência solar sobre a fachada de uma edificação 
Cada elemento construtivo de uma edificação absorve diferentes intensidades de radiação, que variam dependendo dos seguintes fatores: presença de elementos que obstruem as radiações (beirais, persianas, vegetação, etc); absortância (capacidade real de uma superfície absorver uma radiação incidente); emissividade da superfície de vedação (capacidade da superfície em emitir energia por radiação) e orientação solar.

O posicionamento da edificação em relação ao sol é o principal fator de influência da radiação transmitida para o interior do edifício. Essa orientação solar se reflete diretamente na distribuição espacial das aberturas do empreendimento. No hemisfério norte, as moradias costumam ter uma maior quantidade de aberturas voltadas para a face sul em relação às demais. Ainda que os maiores ganhos de radiação ocorram nas vedações transparentes (janelas), as radiações solares nos materiais opacos (alvenaria, acabamento, etc.) não podem ser desprezadas (LAMBERTS, 2013).

Segundo WASSOUF (2014, p.23), as vedações opacas possuem pouca influência no balanço energético necessário para climatizar uma edificação em climas temperados do centro-europeu, já que os ganhos pela radiação solar de onda curta (ultravioleta) se equilibram com as perdas geradas pela irradiação solar do material opaco (ondas longas) durante o período noturno. Em climas tropicais quentes se torna necessário levar em consideração no balanço energético do edifício o fluxo de energia decorrente da radiação solar sobre os materiais opacos, já que no verão esse mesmo material gera um grande impacto no balanço de energia total do empreendimento.

No hemisfério norte, onde a Passivhaus é largamente aplicada, é possível constatar que a melhor orientação das fachadas de um edifício face ao sol é a voltada para o sul, aproveitando uma maior entrada de radiação solar no inverno, protegendo-o no verão (Figura 3).

Exemplificando, no caso da Alemanha, que possui um clima temperado, com inverno rigoroso e verão quente, uma orientação voltada para o sul permite que os ganhos solares sejam maximizados no inverno, recebendo uma maior radiação no interior da estrutura. Esse fato reduz a necessidade de sistemas de calefação na edificação, otimizando o conforto térmico de seus usuários de forma passiva (LAMBERTS, 2013). 
Aberturas no hemisfério norte orientadas para leste e oeste devem ser reduzidas por possuírem uma maior incidência de radiação solar no verão e pouca no inverno. Com aberturas maiores na direção sul, o ângulo de incidência de radiação solar no verão, permite uma proteção relativamente mais fácil de se implantar em relação à orientação leste ou oeste (LAMBERTS, 2013).

Maiores aberturas localizadas na orientação norte (Hemisfério Norte) possuem um pior balanço energético, pois recebem pouca radiação solar no inverno, apresentando perdas energéticas altas por transmissividade térmica dos elementos estruturais. Assim, uma residência no hemisfério norte com uma maior quantidade de aberturas voltadas para o sul e a restrição de aberturas nas demais orientações, deve ser a forma ideal para edifícios energeticamente eficientes (WASSOUF, 2014).

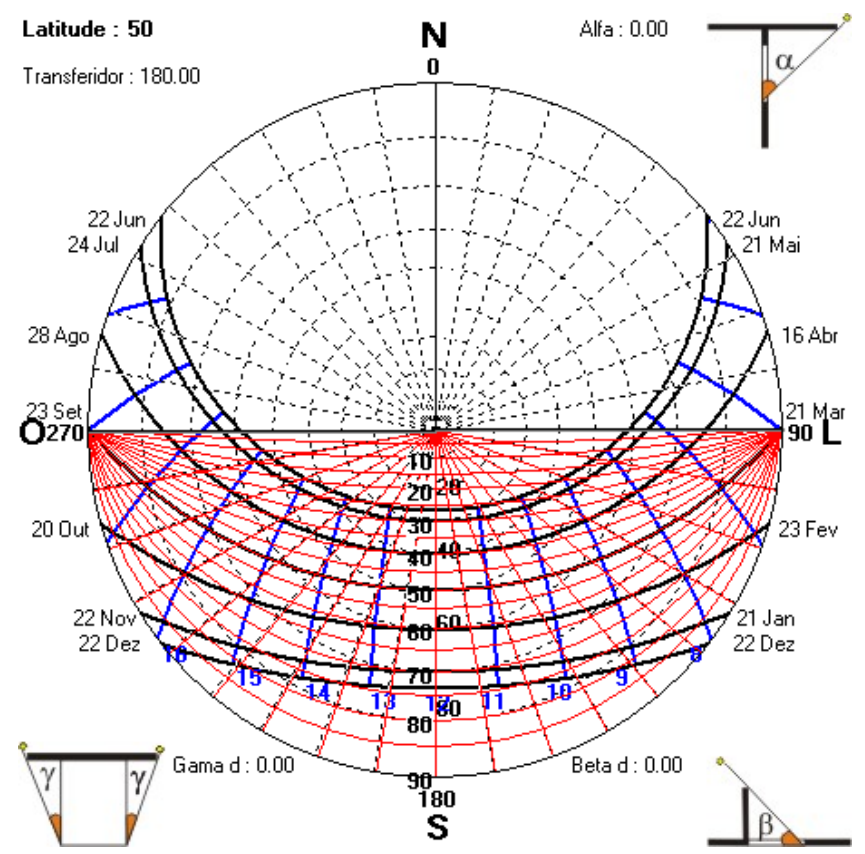

Figura 3 - Carta solar do hemisfério norte na latitude 50 (Alemanha) Fonte: Programa Sol - Ar 6.2 UFSC, 2015

No hemisfério sul, a trajetória solar é espelhada $180^{\circ}$ com relação a orientação solar do hemisfério norte. Desta forma, países localizados abaixo da linha do Equador recebem uma maior radiação solar com suas respectivas aberturas voltada para a orientação norte (Figura 4). A orientação sul para aberturas e fachadas principais recebe pouca radiação solar no inverno. Já no verão, recebe radiação 
solar nas primeiras horas da manhã e nas últimas horas da tarde (MASCARÓ, 1986).

Orientações voltadas para o leste e oeste possuem ganhos energéticos similares (Hemisfério Sul), porém em momentos diferentes. Fachadas e aberturas na orientação leste recebem radiação solar durante as primeiras horas do dia; já na orientação oeste, a radiação solar ocorre de uma maneira mais incidente no final do dia. De uma maneira geral, o balanço energético de uma residência com maiores aberturas na direção oeste é inferior ao de maiores aberturas na direção leste. Ambientes voltados para o oeste são mais quentes em relação à direção leste, apesar de receberem o mesmo número de horas de sol (MASCARÓ, 1986).

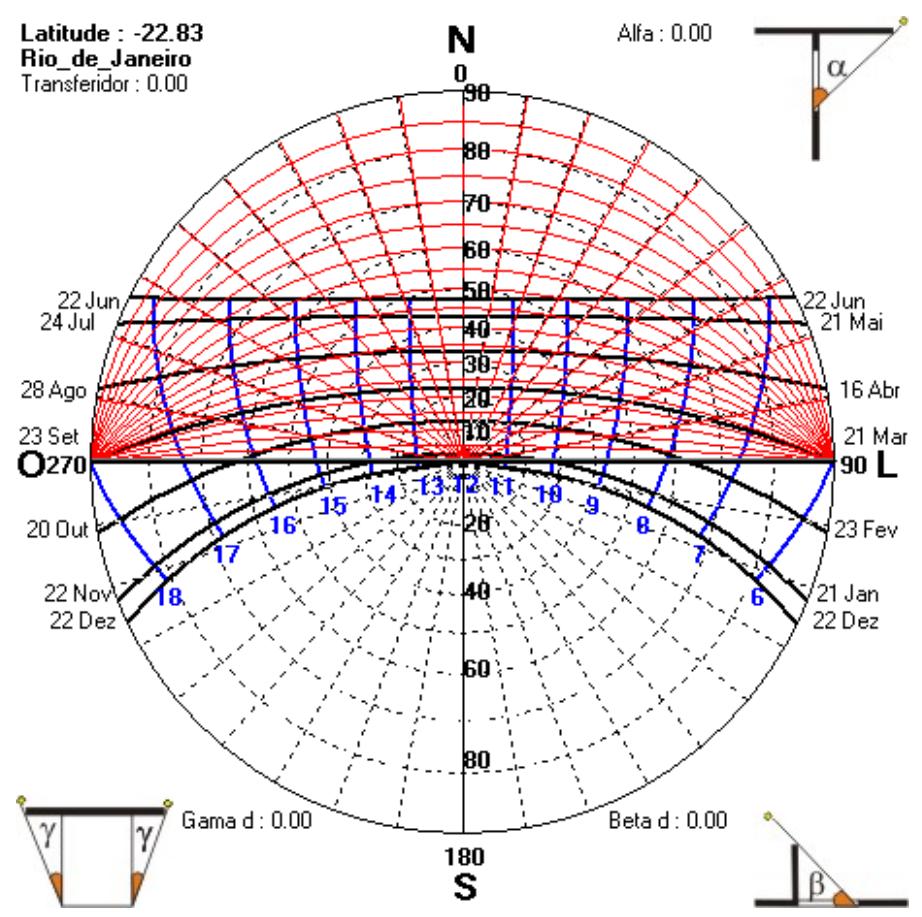

Figura 4 - Carta Solar do hemisfério sul na latitude 22.83 (Rio de Janeiro) Fonte: Programa Sol - Ar 6.2 UFSC, 2015

Podemos destacar que climas quentes possuem uma maior influência da orientação solar no balanço energético total de uma edificação. Ambientes com baixa incidência da radiação solar possuem uma variação no seu balanço energético menor, pois sua orientação solar possui uma menor influência no equilíbrio térmico. Deste modo, edificações localizadas em grandes e densos centros urbanos, caracterizando uma maior área sombreada, possuem uma menor variação no balanço térmico devido à orientação de suas aberturas perante o sol. 
Se faz necessário citar a possibilidade do uso de tecnologias atuais, para incrementar as estratégias de posicionamento das aberturas da edificação. Utilizando diferentes propriedades de transmissividade térmica das vedações existentes, a edificação se torna capaz de aumentar o ganho/perda de energia térmica para o ambiente externo.

Para empreendimentos construídos segundo os critérios da Passivhaus em climas frios, foram desenvolvidas janelas com folhas triplas e introdução de gases nobres (Argônio, Criptônio, Hexafluoreto de Enxofre e Dióxido de Carbono) entre suas folhas (Figura 5). Janelas com essas características apresentam transmitâncias térmicas muito baixas $\left(<0,15 \mathrm{~W} / \mathrm{m}^{2} . \mathrm{K}\right)$ e são ideais para climas frios, onde a redução da perda de calor para o ambiente externo é prioridade (PHI, 2014).

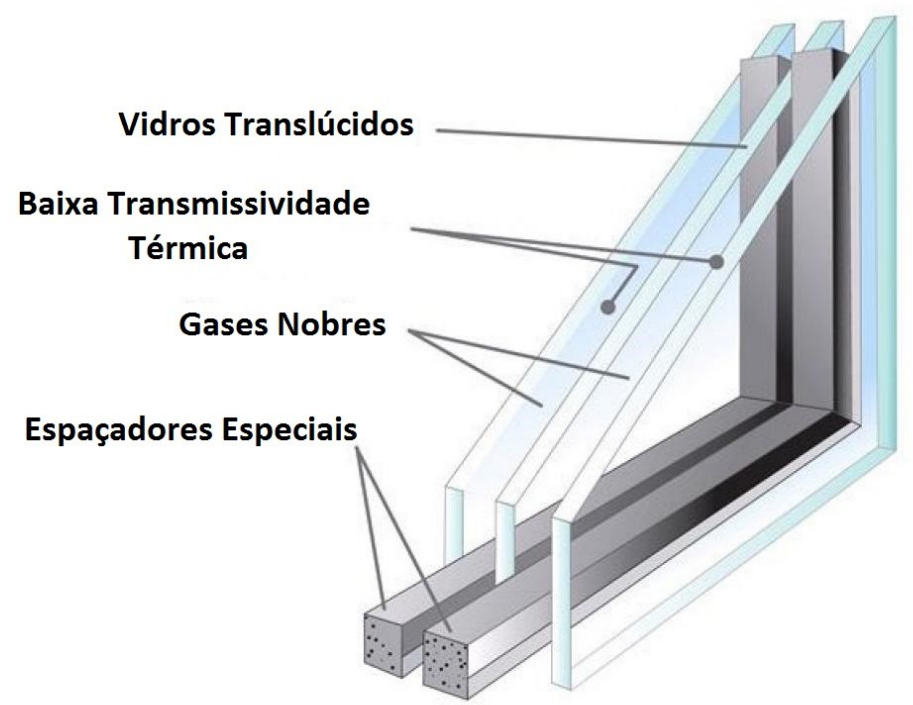

Figura 5 - Janela com folha tripla de vidro, fazendo uso de gases nobres para sua baixa transmissividade térmica

Fonte: www.hgtv.com (Modificada), 2015

Tratando-se de climas tropicais quentes e úmidos, não é necessário o uso desses extremos, porém janelas com elevada resistividade térmica garantem uma menor absorção térmica do edifício, possibilitando o mesmo de sair das normas de orientação passiva, com maiores aberturas para a direção sul (Hemisfério Sul).

Uma baixa transmissidade térmica dos elementos constituintes da edificação possibilita uma independência da orientação das aberturas perante o sol, reduzindo o consumo energético para climatização do ambiente utilizando sistemas convencionais para refrigeração (CORBELLA \& YANNAS, 2003). 


\section{Impacto do Vento}

Segundo LAMBERTS (2013), existem dois tipos de mecanismos de ventilação. A ventilação natural, que é causada pela diferença de pressão e temperatura entre o ambiente interno e externo do edifício; e a ventilação forçada, realizada por equipamentos mecânicos.

Diferente da orientação solar, as correntes de ar possuem uma lógica de estudo mais complexa, dependendo de casualidades climáticas. Desta maneira, torna-se errôneo generalizar uma orientação de um edifício como ótima, levando em consideração apenas a radiação solar. Sabe-se que em climas tropicais quentes, busca-se uma orientação das aberturas capazes de captar as correntes de ar dominantes e dissiparem o calor acumulado em uma edificação (Figura 6). Já em climas temperados frios, a arquitetura passiva buscou soluções capazes de reduzir ao máximo a entrada de correntes de ar invernais no edifício através de suas juntas (MASCARÓ, 1991).

Assim, os estudos da arquitetura passiva devem avaliar a radiação solar e o impacto do vento no edifício, priorizando uma orientação das aberturas que causem um menor impacto no balanço energético do mesmo.

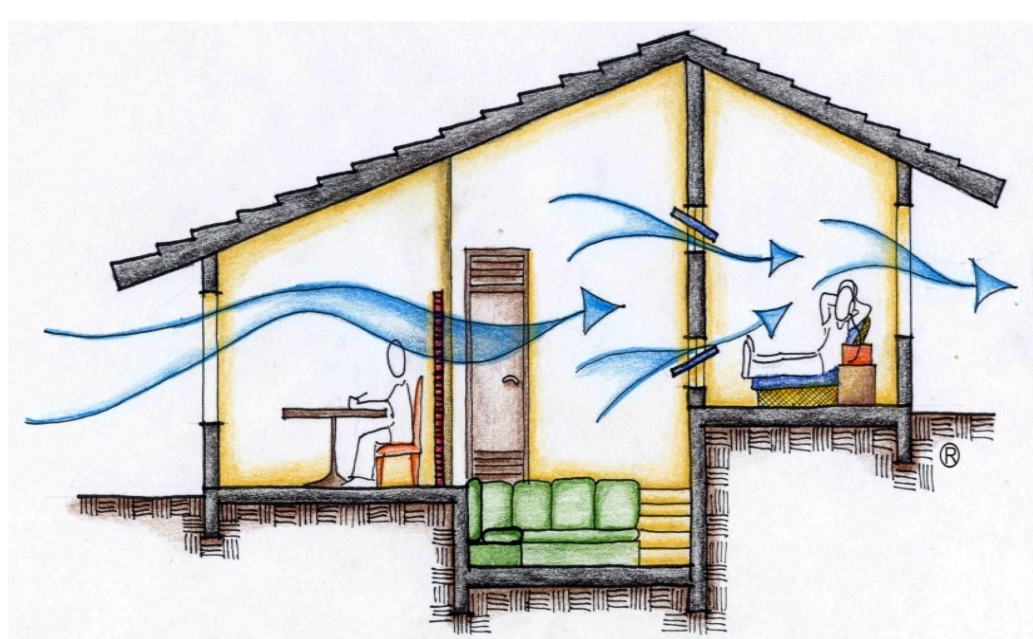

Figura 6 - Ventilação com fluxo cruzado, retirando o calor do ambiente interno Fonte: http://150.162.76.139/aplicacao/29/, 2015 


\section{Índice de Compacidade}

Segundo WASSOUF (2014, p. 26), o índice de compacidade "é o quociente entre a superfície das vedações externas da edificação e o volume que esta encerra”. Esse conceito é aplicado na arquitetura passiva, favorecendo ou não a troca de calor do edifício com o meio externo, através de suas vedações.

Em climas temperados com inverno rigoroso como na Alemanha e em regiões do centro-europeu, uma infraestrutura portando baixo índice de compacidade $(0,2-0,5 / \mathrm{m})$, representa uma menor perda de calor interno para o meio externo, em comparação a uma infraestrutura de mesmo volume. Desta forma, uma maior eficiência energética é atingida pelo menor consumo de energia para a calefação do ambiente (SCHNIEDERS, 2009).

Já em climas tropicais quentes e úmidos, como boa parte do Brasil, um edifício com alto índice de compacidade $(0,6-1 / \mathrm{m})$, poderá gerar uma maior quantidade de sombra própria, além de facilitar o fluxo de ar entre suas vedações com o meio externo. Possuindo um maior sombreamento, edificações localizadas nesse clima possuem, consequentemente, uma menor demanda de energia térmica necessária para sua climatização (WASSOUF, 2014).

SCHNIEDERS (2009) relata que edifícios com baixo índice de compacidade em climas tropicais quentes e úmidos podem também apresentar efeitos negativos quanto à dissipação de energia interna no verão. Isso pode ser relatado na condição das temperaturas externas médias diurnas de uma edificação serem mais baixas que as temperaturas no seu interior.

Devemos salientar novamente a importância da tecnologia para alterar as estratégias de dissipação e armazenamento de energia interna. Edificações com altos índices de compacidade podem receber vedações com propriedades de baixa transmissividade térmica, assim como aberturas menores nas orientações onde recebem maiores quantidades de radiação solar, compensando, desta forma, seu índice de compacidade.

O fator índice de compacidade, assim como a orientação solar e o impacto do vento, não devem ser analisados individualmente, mas sim em conjunto para uma melhor conformidade da arquitetura passiva, lembrando as medidas compensativas ou corretivas da tecnologia. 


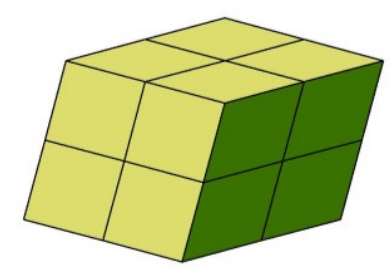

(A)

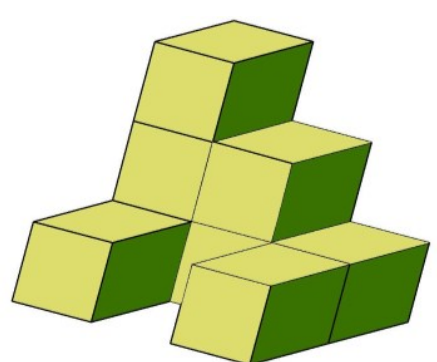

(B)

Figura 7 - Exemplo onde um mesmo volume pode apresentar compacidades diferentes

\section{Proteção Solar}

A radiação solar é essencial para o aumento da temperatura interna de uma edificação no inverno. Essa vantagem se torna inconveniente no verão, pois pode acarretar a diminuição do conforto interno. Assim, tornam-se necessários estudos arquitetônicos e de engenharia para otimizar o ganho de radiação solar no inverno e sua minimização no verão. Uma maneira de alcançar esse objetivo é a utilização de protetores solares.

Existem diversos tipos de protetores solares arquitetônicos, como brises, marquises, beirais, persianas, toldos etc. Os protetores solares existentes são classificados em duas categorias: protetores móveis e protetores fixos. Os protetores fixos podem ser menos adaptáveis às condições climáticas locais, como no caso de primaveras ou outonos frios, tornando-se necessário o aquecimento interno da edificação. Já os mesmos possuem vantagens como valores mais econômicos de implantação e menores custos de manutenção. Protetores solares móveis ou reguláveis costumam ter uma vida útil menor comparativamente aos fixos (WASSOUF, 2014).

Em climas tropicais, onde a temperatura diurna do ambiente no inverno é elevada, torna-se interessante o uso de protetores solares fixos e bem amplos, como brises. A proteção solar no inverno tem o mesmo objetivo que nas demais estações. A arquitetura de um ambiente localizado em uma zona tropical quente é bem característica e desenvolvida para uma melhor proteção da radiação solar durante $\mathrm{o}$ ano todo, evitando um superaquecimento interno do edifício (LAMBERTS, 2013).

Em climas continentais, como no leste alemão, possuindo invernos rigorosos e verões quentes, uma edificação com baixo consumo energético, seguindo os critérios Passivhaus, deve ter a eficiência do seu sistema de proteção solar aferida 
e otimizada. Esse sistema de proteção solar deve proteger o interior da edificação durante o dia e minimizar a dissipação do calor interno durante a noite (WASSOUF, 2014).

Proteções solares excessivas podem comprometer o sistema de iluminação passiva de um edifício. Desta forma, um maior gasto energético devido ao consumo elétrico de iluminação artificial se faz necessário para suprir a necessidade de iluminação passiva solar (LAMBERTS, 2013).

Segundo a apostila "Bioclimatismo no Projeto de Arquitetura: Dicas de Projeto" (FAU-UFRJ, 2005), o valor que define o grau de proteção solar é o coeficiente Cs. Esse coeficiente pode ser definido pela percentagem de radiação luminosa obstruída por um determinado objeto arquitetônico. Muitos produtos presentes no mercado possuem valores de Cs caracterizados em laboratório, portanto os dados do fabricante sobre o fator de proteção à radiação solar são bastante otimistas, diferentes dos resultados dos mesmos em situação real.

No Brasil não existe atualmente uma normatização de caráter neutro, medindo os diferentes valores do coeficiente de sombreamento entre os sistemas de proteção solar. Faz-se apenas uma menção quanto à sua definição na ABNT 15220-1 (2003).

A Faculdade Federal de Arquitetura e Urbanismo do Rio de Janeiro (FAU-UFRJ) descreveu os principais valores do coeficiente de sombreamento dos diferentes elementos arquitetônicos utilizados em projetos (Tabela 3).

Tabela 3 - Diversos fatores de sombra normalmente utilizados em projeto

\begin{tabular}{c|c}
\hline Objeto Arquitetônico & Cs \\
\hline Brises verticais (E-O) de cor clara (para lat. 30 ${ }^{\circ} \mathrm{S}$ ) & 0,40 \\
\hline Brises verticais (E-O) de cor média (para lat. 30 $\mathrm{S}$ ) & 0,50 \\
\hline Brises horizontais (N-S) de cor clara (para lat. 30 $\mathrm{S}$ ) & 0,50 \\
\hline Brises horizontais (N-S) de cor média (para lat. 30 $\mathrm{S}$ ) & 0,60 \\
\hline Toldo de cor clara & $0,6-$ \\
\hline Toldo de cor escura & 0,80 \\
\hline Persiana de enrolar, fechada, deixando de abertura 5\%, cor clara & 0,80 \\
\hline Persiana de enrolar, fechada, deixando de abertura 5\%, cor escura & 0,90 \\
\hline Cortina de trama fechada, cor clara & 0,70 \\
\hline Cortina de trama fechada, cor escura & 0,85 \\
\hline Cortina de tecido de trama aberta, cor clara & 0,30 \\
\hline Cortina de trama aberta, cor escura & 0,50 \\
\hline Persiana de cor clara & 0,60 \\
\hline Persiana de cor escura & 0,80
\end{tabular}

Fonte: Apostila "Bioclimatismo no Projeto de Arquitetura: Dicas de Projeto" (FAU-UFRJ, 2005), página 66. 
Existe no mercado uma gama de proteções solares móveis com sistemas automatizados de entrada de luz em função da intensidade da luz incidente nas aberturas, do ofuscamento e de outros fatores sendo controlados por sensores inteligentes de presença e iluminação. Cita-se a empresa norte-americana Loxone, que desenvolve sistemas de automação em proteções solares móveis, capazes de controlar a luminosidade interna, realizando a filtração de raios ultra-violetas incidentes. Há também sistemas inteligentes capazes de se conectar a dados meteorológicos locais adotando estratégias baseadas em suas previsões (LOXONE, 2016).

\section{Refletância Solar}

Segundo DEKAY (2004, p.369), a refletância solar é "a capacidade de um determinado material de rejeitar o calor solar, avaliada pela sua elevação de temperatura quando completamente exposto ao sol”. Esta é uma estratégia usada para diminuir a absorção da radiação solar das superfícies externas de uma edificação durante o verão, sem a qual o aumento de temperatura interna de um ambiente seria sentido, devido à irradiação das superfícies externas para seu interior.

Quanto maior a refletância solar de um material, menor a sua capacidade de absorver calor e consequentemente menor será a demanda energética para a climatização de uma edificação no verão. A refletância solar é conceituada como uma grandeza física, correspondendo ao "quociente da taxa de radiação solar refletida por uma superfície, pela taxa de radiação solar incidente sobre a mesma superfície" (NBR 15220, 2003).

O maior valor do índice de refletância solar entre os materiais é 1. Uma simples variância entre um material que possui $0,1-0,3$ para um material entre 0,6-0,7 de refletância solar, pode diminuir em 20-25 \% a demanda de refrigeração interna de uma edificação no verão (WASSOUF, 2014).

Assim como a proteção solar, não há uma normatização brasileira que avalie de uma forma neutra e confiável os índices de refletância solar dos diferentes materiais e suas eficiências ao longo prazo. Há apenas a menção de sua definição na norma ABNT 15220-1 (2003). Desta forma, faz-se necessário buscar publicações relacionadas a pesquisas sobre a refletância solar entre os diferentes materiais, 
para a avaliação do balanço energético no interior da edificação, em diversas condições climáticas.

A Tabela 4 mostra a refletância solar de superfícies feitas com diferentes materiais, segundo o Cool Roof Rating Council (CRRC), uma organização americana criada em 1998, desenvolvendo métodos apurados para avaliação da performance dos diferentes produtos empregados em telhados, medindo suas eficiências em relação à radiação solar e emissividade térmica (CRRC, 2013).

Tabela 4 - Valores de refletância dos diferentes materiais em análise

\begin{tabular}{c|c}
\hline Tinta acrílica Preta & 0,05 \\
\hline Tinta acrílica Branca & 0,8 \\
\hline Asfalto novo & 0,05 \\
\hline Asfalto antigo & 0,1 \\
\hline Concreto novo & $0,34-0,45$ \\
\hline Concreto antigo & $0,2-0,3$ \\
\hline Telha de concreto clara & 0,21 \\
\hline Folhas verdes de árvores & $0,29-0,21$ \\
\hline Piso de Ardósia & 0,12 \\
\hline Neve Limpa & $0,65-0,8$ \\
\hline Telha Cerâmica Vermelha & 0,25 \\
\hline Mármore branco & 0,54 \\
\hline
\end{tabular}

Fonte: http://coolroofs.org/products/results, 2013

Devemos destacar as novas tecnologias no mercado para refletância solar. Citamos a empresa Nanotech no Brasil, desenvolvedora de uma tinta ecológica feita a base de água e capaz de reduzir em até $35 \%$ a temperatura de ambientes internos e em $30 \%$ ruídos de chuva. O composto foi idealizado com materiais de alta refletância solar, baixa absorção e pequeno valor de condutibilidade térmica, podendo ser aplicada em coberturas de cerâmica, concreto, metal, plástico, telhados, etc. (NanoTech, 2015).

\section{Controle de Umidade}

A arquitetura passiva pode fazer uso do resfriamento evaporativo como um instrumento para climatização do ambiente, sem que haja o consumo energético referente aos sistemas de resfriamento ativo. Seu mecanismo de funcionamento se deve às correntes de vento, à propriedade do ar quente de se sobrepor ao ar frio (por este ser mais denso) e à capacidade da água de resfriar o ambiente durante o 
processo de evaporação, através da transformação de calor sensível em calor latente.

A eficiência do resfriamento evaporativo pode ser diretamente relacionada à umidade do ambiente. $\mathrm{O}$ ar em uma dada temperatura pode conter uma certa quantidade de partículas de água. Quanto maior a temperatura do ar, menos denso ele se torna, possibilitando, assim armazenar uma maior quantidade de água. O conteúdo máximo que o ar pode conter de água a uma dada temperatura dá-se o nome de grau de saturação. Nessa condição, qualquer quantidade superior de água no ponto de saturação, condensará (LAMBERTS, 2013).

Quando o conteúdo de água presente no ar for menor que a quantidade de água que o ar, com uma determinada temperatura, pode suportar, diz-se que essa proporção é a umidade relativa do ar.

Em locais de baixa umidade, caracterizados, desta forma, como clima seco, a variação entre os extremos de temperatura mínima e máxima é relativamente grande. Já em locais de alta umidade, sua variação tende a se reduzir.

A umidade do ar pode ser modificada pelas condições locais próximas às edificações, quando se tem a presença de água ou vegetação. Em edifícios próximos a massa de água (rios, oceanos, fontes e espelhos d'água), ocorre uma diminuição da temperatura no ambiente pelo umedecimento do ar (LENGEN, 2014).

A vegetação resfria o ar ao redor pelo processo de evapotranspiração do mesmo. Uma superfície com vegetação absorve uma maior quantidade de calor (devido ao metabolismo vegetal), refletindo uma menor quantidade de radiação, além de facilitar a dissipação do calor por convecção entre as folhas, em comparação a uma superfície sem cobrimento vegetativo (LAMBERTS, 2013).

Assim, o projetista deve considerar as condições climáticas e adotar técnicas adequadas para favorecer o conforto térmico das edificações, resultando em economia de energia, gasta para aquecimento ou resfriamento do ambiente e, consequentemente, melhorando o desempenho energético da edificação. 


\section{4. \\ A edificação Passivhaus}

\section{1}

\section{Considerações de sua arquitetura}

Nos itens que se seguem, introduziremos seus conceitos, processos e objetivos. Será realizada uma introdução de determinados critérios passivos vistos a partir de sua perspectiva. Esses conceitos vão além do limite dos conceitos básicos da arquitetura passiva, propondo um protocolo para alcançar demandas energéticas muito baixas.

Devemos destacar que não existe apenas uma solução determinada dentro do protocolo, mas, sim, um caminho a ser seguido, para se obter uma redução da demanda energética e alto conforto térmico a ser atingido por uma edificação.

Por se tratar de um método desenvolvido na Alemanha, salienta-se a necessidade de uma análise dos conceitos de seu protocolo para climas tropicais quentes. Essa análise deve ser feita por uma ferramenta de cálculo adequada; o Passivhaus Planning Package, elaborado pela Passive House Institute. O mesmo tornase necessário, dado que uma solução energética ideal depende de uma variedade de parâmetros climáticos locais.

Uma edificação com um baixo consumo energético pode ser caracterizada pelo alto isolamento térmico, ser livre de pontes térmicas, possuir um sistema de ventilação mecânica eficiente e apresentar alta estanqueidade ao ar (BRE, 2015).

Não há uma exigência da norma quanto ao uso de materiais para a construção dos edifícios. Desta forma, o projetista pode produzir modelos de construções típicas européias, com paredes ocas de alvenaria ou madeira. Construções alternativas, mais comumente encontradas nos projetos em ambientes continentais, utilizam alvenaria sólida (concreto), com materiais isolantes externos (PHI, 2014).

Segundo o Passive House Institute (2014), o custo da construção de uma edificação deve ser o mais baixo possível; desta forma, o uso de materiais de construção ecologicamente sustentáveis, muitas vezes mais caros, opõe-se a uma redução dos custos de produção. Frisa-se que, a norma não aborda questões en- 
volvendo a sustentabilidade no ciclo de vida dos materiais da obra, não cabendo o desenvolvimento de uma avaliação detalhada do impacto ambiental de determinado material no ambiente. Porém, como dito anteriormente, a certificação pode ser complementada com as demais certificações ambientais, resultando em empreendimentos com alta eficiência energética, confortáveis e possuindo uma certificação com ampla gama em questões de sustentabilidade (PHI, 2014).

\section{Isolamento Térmico}

$\mathrm{O}$ isolamento térmico de uma edificação serve para proteger o ambiente interno das condições climáticas externas. Uma característica chave de uma estrutura construída segundo a norma é a incorporação de padrões elevados de isolamento térmico, diminuindo a variação térmica entre o meio externo e o interno. Essa característica é muito eficaz em climas secos, onde a variação de temperatura é elevada.

No inverno, uma estrutura com um alto isolamento térmico reduz a perda energética para o meio externo, garantindo uma qualidade de conforto térmico na edificação, com uma economia dos sistemas de calefação.

No verão, uma redução dos ganhos térmicos da estrutura será alcançada pelo alto isolamento térmico, reduzindo os gastos energéticos com a refrigeração. Em climas onde a variação das temperaturas máximas e mínimas diárias é pequena, há uma menor eficiência dos isolamentos térmicos (PHI, 2014).

O isolamento térmico é descrito através da transmissividade térmica (valor $\mathrm{U})$ de um material, cuja unidade é em $\mathrm{W} / \mathrm{m}^{2} . \mathrm{K}$. O valor $\mathrm{U}$ é uma medida de perda de calor, mostrando a quantidade de calor perdida em watts (W) por metro quadrado de um determinado material (paredes, lajes, janelas, portas etc) quando a diferença de temperatura entre o interior e o exterior é de 1 Kelvin (K).

Tiramos como exemplo a transmitância térmica de uma alvenaria típica, com tijolos de 6 furos, rebocada em ambas as faces, com espessura total de 15 centímetros, no valor de $2,28 \mathrm{~W} / \mathrm{m}^{2} . \mathrm{K}$. Ou seja, uma vedação de 1 metro quadrado deixa passar 2,28 Watts quando a diferença de temperaturas entre o meio interno e externo é 1 Kelvin. A energia trocada por condução entre o meio interno e o externo é derivada da diferença da temperatura dos meios (WASSOUF, 2014). 
Segundo WASSOUF (2014, p.32), há uma ideologia pré-concebida no meio dos projetistas de edificações de que o alto isolamento térmico da edificação afetaria seu desempenho térmico no verão, pela dificuldade de dissipação do calor acumulado durante o dia em períodos noturnos. Essa concepção se torna verdadeira em edificações com má compatibilidade térmica (mal projetadas e desprotegidas), quando encontramos um sistema de ventilação deficiente durante a noite.

Em construções que contém um sistema controlado de ganhos de energia térmica no verão, aliado a uma ventilação noturna eficiente, um sistema de alto isolamento térmico deverá produzir uma melhora no desempenho energético nos períodos mais quentes.

A norma brasileira NBR 15220 (2003) é dirigida para análise do desempenho térmico das edificações. As propriedades térmicas dos materiais, paredes e coberturas mais comumente utilizados na construção civil estão descritas em seu anexo D.

Considera-se a espessura da camada isolante dos materiais inversamente proporcional à sua transmissividade térmica. Quanto maior a espessura da camada em análise, menor a capacidade do material em transmitir calor devido à diferença de temperatura interna e externa. A figura 8 demonstra valores de transmissividade térmica dos diferentes tipos de alvenaria existentes, com suas respectivas espessuras (NBR 15220, 2003).

Segundo LAMBERTS (2013, p.15), os materiais convencionalmente utilizados no mercado que possuem elevadas propriedades de isolamento térmico são:

- $\quad$ Lã de rocha;

- $\quad$ Lã de vidro;

- $\quad$ Espuma de poliestireno;

- Concreto celular;

- $\quad$ Argila expandida; 


\begin{tabular}{|l|l|}
\hline Descrição & $\begin{array}{r}\text { Transmissividade } \\
\text { Térmica } \\
\left.\text { [W/( }\left(\mathrm{m}^{2} . \mathrm{K}\right)\right]\end{array}$ \\
\hline
\end{tabular}

Figura 8 - Transmissividade térmica de diferentes alvenarias segundo NBR15220 Fonte: NBR 14220, 2003

Destaca-se que, para um valor de transmissividade térmica (U), correspondente a $0,22 \mathrm{~W} / \mathrm{m}^{2} . \mathrm{K}$, uma alvenaria de tijolo rebocado em ambas as faces precisa ter espessura de $20 \mathrm{~cm}$; para o mesmo valor $\mathrm{U}$, uma espessura de $1 \mathrm{~cm}$ utilizando como material a lã de vidro é suficiente. Esse fato demonstra a capacidade de iso- 
lamento térmico de determinados materiais não normatizados (LAMBERTS, 2013).

Para atingir o critério Passivhaus referente à demanda energética, faz-se o uso de materiais com baixa transmissividade térmica (inferior a $0,15 \mathrm{~W} / \mathrm{m}^{2} . \mathrm{K}$ ). Assim, uma gama de materiais existentes no mercado, com diferentes propriedades térmicas, podem ser combinados e introduzidos na edificação, resultando em uma alta resistência térmica (PHI, 2014).

Segundo WASSOUF (2014), devido a uma maior incidência de radiação solar em superfícies horizontais durante o verão, prioriza-se maiores espessuras do material isolante térmico em suas lajes, em detrimento das paredes externas verticais.

Lajes inferiores em contato com o solo possuem, em sua grande maioria, isolamento contra a umidade. $\mathrm{O}$ isolamento térmico para lajes de piso térreo podem variar conforme o rigor climático onde forem implantadas, sendo influenciadas pelo nível de água presente no solo.

Em climas quentes, com elevado nível de água no solo, convém um determinado isolamento térmico da laje de piso térreo devido ao processo de evaporação e condensação da água.

Com uma quantidade de energia derivada da radiação solar $(\sim 600 \mathrm{kcal} / \mathrm{kg}$ ou $600 \mathrm{cal} / \mathrm{g}$ ), a água presente no solo entra em processo de evaporação, e, ao se encontrar com a laje térrea da edificação, é desencadeado o processo de condensação, liberando energia, aumentando, assim, a temperatura interna da estrutura.

Em climas temperados, com invernos rigorosos, torna-se essencial a presença de um alto isolamento térmico da laje de piso térreo, evitando-se a perda de calor para o solo. Como regra geral, para edificações Passivhaus com alta qualidade de conforto térmico, a diferença de temperatura entre a superfície do solo e a temperatura média de conforto do interior da edificação não deve superar $3{ }^{\circ} \mathrm{C}$ (ISO 7730-2006), (WASSOUF, 2014).

\section{Inércia Térmica}

Segundo LAMBERTS (1999, p.22), a inércia térmica de uma edificação é a sua "capacidade de absorver e liberar calor". Esse fenômeno está intrinsicamente 
ligado à capacidade e à condutividade térmica dos diferentes elementos construtivos.

Na construção civil, o conceito de inércia térmica está relacionado à transferência de calor entre os meios interno e externo da edificação. Possuindo como propriedade a capacidade térmica da estrutura, a inércia térmica pode ser determinada através da velocidade de absorção e quantidade de calor absorvida pelo material.

Todo elemento construtivo possui uma capacidade de absorção de uma certa quantidade de energia, dependente de sua densidade e capacidade calorífica. A inércia térmica é fisicamente descrita como a energia necessária para aumentar em 1 Kelvin a temperatura de um volume de 1 metro cúbico de um determinado elemento construtivo.

Essa massa térmica é capaz de armazenar energia até seu ponto de saturação, evitando oscilações e picos da temperatura interna em uma edificação durante os períodos mais quentes. Quando a temperatura do elemento construtivo se torna mais alta que a temperatura do ar circulante, o fluxo energético se inverte, passando a fluir a energia do elemento construtivo para o ar.

Em uma edificação com pouca inércia térmica, ocorre de a variação de sua temperatura interna seguir muito próxima à variação da temperatura externa; com uma inércia térmica infinita, a temperatura interna permaneceria constante.

De certa forma, a necessidade de se utilizar materiais com alta inércia térmica na construção (concreto, tijolos, telhas, etc.) aumenta conforme o aumento da variação térmica do meio externo, radiação solar e/ou ganhos de calor. A vantagem da inércia térmica é derivada do amortecimento do excesso de energia térmica que uma edificação pode receber, provinda, principalmente, da radiação solar e das atividades humanas (LAMBERTS, 1999).

A inércia térmica funciona, portanto, como um gestor de energia, sendo comparada ao funcionamento de uma bateria de ciclo diário. $\mathrm{O}$ armazenamento da energia oriunda da radiação solar e das atividades internas da edificação se dá durante o dia, em elementos construtivos com alta inércia térmica.

Para o bom funcionamento de seu conceito, deve haver uma descarga dessa energia armazenada, no período noturno. Caso isso não ocorra, os elementos construtivos permanecem carregados até o dia seguinte, deixando de exercer suas funções de amortecimento e atraso térmico. Essa descarga energética pode ser reali- 
zada de maneiras naturais (correntes de vento cruzadas) ou artificiais (WASSOUF, 2014).

A medida da inércia térmica de um dado elemento construtivo é calculada pelo seu atraso térmico e sua capacidade de amortecimento. O atraso térmico, segundo RIVERO (1986), é o tempo em que uma diferença térmica ocorrida em um dos meios se manifesta em sua superfície oposta. O atraso térmico corresponde à defasagem térmica entre as ondas no interior da construção em relação ao seu exterior durante um período de 24 horas.

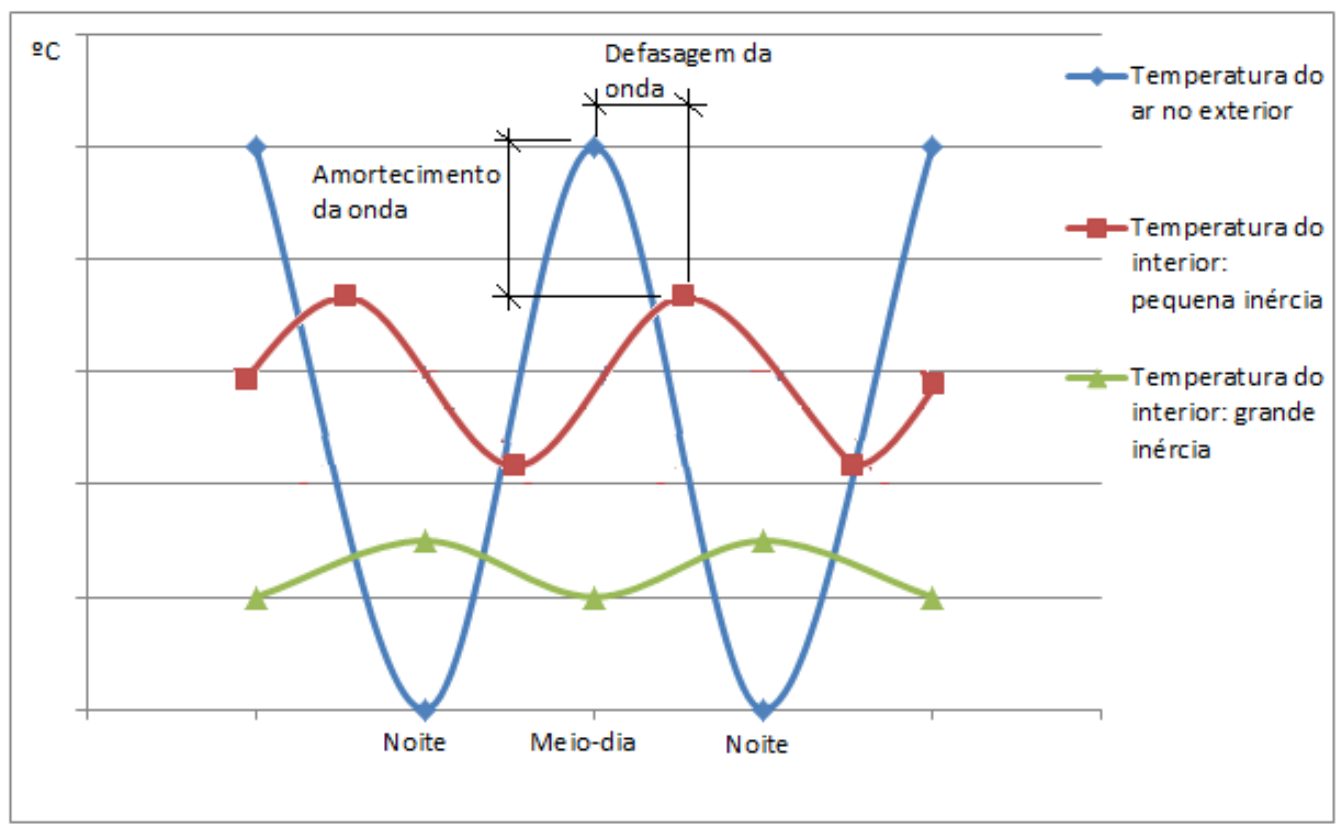

Figura 9 - Defasagem e amortecimento da onda térmica

A capacidade de amortecimento (Figura 9) é a capacidade do elemento construtivo de diminuir a amplitude das variações térmicas, descrevendo a oscilação das temperaturas internas em comparação com as externas (RIVERO, 1986).

A inercia térmica em climas quentes se torna vantajosa tanto no inverno quanto no verão. No inverno, durante o período diurno, um edifício com uma elevada massa térmica absorve o excesso de radiação proveniente do sol, amortecendo e postergando a dissipação da energia absorvida pelo elemento construtivo para o ambiente interno durante o período noturno.

Em outra edificação, submetida às mesmas características climáticas, que apresente baixa inércia térmica, o excesso de radiação seria convertido em aumento da temperatura interna, tendo-se que recorrer a formas de dissipação de energia, como ventilação cruzada, mecânica, etc. No verão, uma edificação com alta inér- 
cia térmica regula melhor as variações de temperatura, reduzindo suas oscilações (CORBELLA \& YANNAS, 2003).

Apesar das propriedades encontradas nos elementos estruturais de alta inércia térmica, as edificações localizadas em climas quentes priorizam diferentes estratégias para desacelerar seu ganho de energia. Opta-se pelo uso de materiais com maiores índices de refletância solar em detrimento a materiais de maior massa térmica. Esse fato é justificado por se preferir refletir o excesso de calor da edificação em contrapartida à sua absorção para posterior dissipação (WASSOUF, 2014).

\section{Pontes Térmicas}

Segundo a PASSIVHAUS TRUST (2014), pontes térmicas são junções e ligações entre os diferentes elementos construtivos, na qual a falta de uma unidade construtiva entre eles gera uma zona de ocorrência de trocas térmicas indesejadas, devendo serem reduzidas ou eliminadas.

As pontes térmicas podem ser classificadas como lineares ou pontuais. A ponte térmica linear (ou bidimensional) ocorre na junção entre 2 elementos construtivos (ex: entre a laje e parede). A ponte térmica pontual (ou tridimensional) ocorre na interseção entre três elementos construtivos diferentes (ex: o canto gerado na junção de duas paredes e uma laje). A Figura 10 mostra algumas áreas comuns de uma edificação onde as pontes térmicas podem ocorrer (PHI, 2013). 


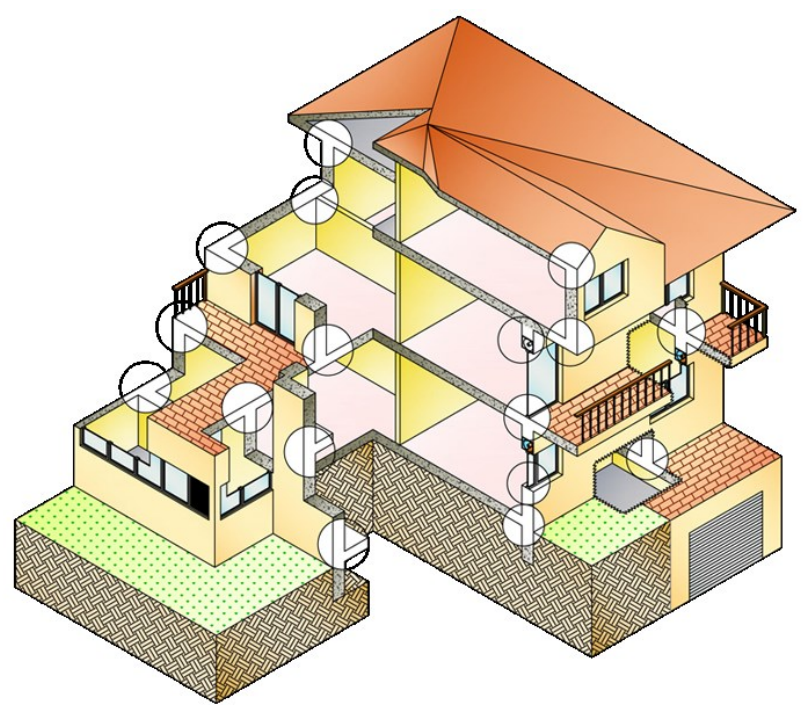

Figura 10 - Zonas onde são encontradas comumente pontes térmicas Fonte: www.passiv.de. 2013

Em edifícios com baixo desempenho energético, as pontes térmicas se tornam menos relevantes devido à magnitude da transferência de calor entre seu interior e o exterior por meio das vedações homogêneas. Já em construções localizadas em climas frios do centro-europeu, onde as perdas térmicas de seu interior por convecção ou ventilação são bastante reduzidas, a existência de pontes térmicas pode resultar em condensações superficiais e intersticiais, comprometendo a higiene interna pelo surgimento de mofo, além de ocasionar a perda de energia térmica (PASSIVHAUS TRUST, 2014).

O conceito "zero termal bridging" (zero pontes térmicas) adotado pela Passive House Institute pode ser empregado em construções que possuírem uma transmitância térmica linear não superior a $0,01 \mathrm{~W} / \mathrm{m}^{2} . \mathrm{K}$. Para garantir essa baixa transmissividade térmica das junções entre diferentes elementos construtivos, algumas regras devem ser atendidas (PHI, 2013):

- Junção: Diminuição da interrupção das camadas de isolamento térmico entre os diferentes elementos construtivos;

- Penetração: Quando houver a impossibilidade de evitar a interrupção da camada de isolamento térmico contínua, deve-se utilizar no ponto de ruptura um elemento com alta resistência térmica;

- Proteção: Proteção dos materiais isolantes dos possíveis danos mecânicos causados na sua instalação. 
As pontes térmicas, em climas quentes, não possuem a mesma relevância no balanço energético de uma edificação da mesma forma que em climas frios. $\mathrm{O}$ impacto energético gerado por pontes térmicas de uma construção localizada em uma região de clima tropical quente e úmido, varia conforme a necessidade térmica da edificação.

Nesse clima, o gradiente de temperatura no inverno entre o interior e exterior da edificação tende a ser reduzido, levando a um baixo impacto energético das pontes térmicas no balanço de energia final. No verão, estação caracterizada por apresentar elevadas temperaturas externas, para a manutenção do conforto interno, as pontes térmicas devem ser reduzidas ou eliminadas, pois contribuem para o aquecimento do edifício (WASSOUF, 2014).

\section{Vedações térmicas semitransparentes}

Assim como as vedações térmicas opacas (lajes, parede, cobertura, etc.), as vedações térmicas semitransparentes (janelas), possuem um papel importante no isolamento térmico da edificação. As janelas, por serem peças ou elementos construtivos energeticamente mais frágeis em comparação às vedações gerais de um edifício, possuem critérios mais rigorosos. Para garantir o conforto térmico no interior da edificação, a transmissividade térmica das janelas deve ser inferior a $0,8 \mathrm{~W} / \mathrm{m}^{2} . \mathrm{K}$, possuindo valores maiores de transmitância térmica em relação às vedações opacas, devido a perdas energéticas através do vidro, esquadrias e espaçadores entre as chapas de vidro (PHI, 2013).

O Solar Heat Gain Coefficient (SHGC), definido como a medida de calor solar que é transmitida para o interior do ambiente, é um importante critério para aquisição de janelas visando uma melhoria nos sistemas de calefação ou resfriamento de uma edificação. Em construções localizadas na Europa central, a norma preconiza a utilização de janelas com fatores SHGC altos, pois uma maior incidência de radiação solar entrará através das vedações semi-transparentes, aquecendo passivamente o ambiente interno (PASSIVHAUS TRUST, 2014).

Em climas quentes e úmidos, as janelas necessitam de SHGC mais baixos para impedir a entrada da radiação solar na edificação. 
O Lawrence Berkeley National Laboratory (LBNL, 2013) relata o aumento da eficiência energética das janelas nos últimos anos, gerando influências diretas a curto, médio e longo prazo no aumento do conforto interno da edificação, na redução do uso de sistemas mecânicos de resfriação/calefação e na redução da emissão de poluentes vindo dos mesmos.

Nos Estados Unidos, o LBNL estima que seria obtida uma redução do gasto energético em edificações, no período entre 1996-2010, de $25 \%$ se as mesmas tivessem adotado janelas energeticamente mais eficientes, com filmes de baixa emissividade, gases de baixa condutividade e outras tecnologias. A

Figura 11 mostra a variação da demanda energética anual para o resfriamento de edificações nos Estados Unidos, conforme o uso de diferentes tipos de janelas (LBNL, 2013).
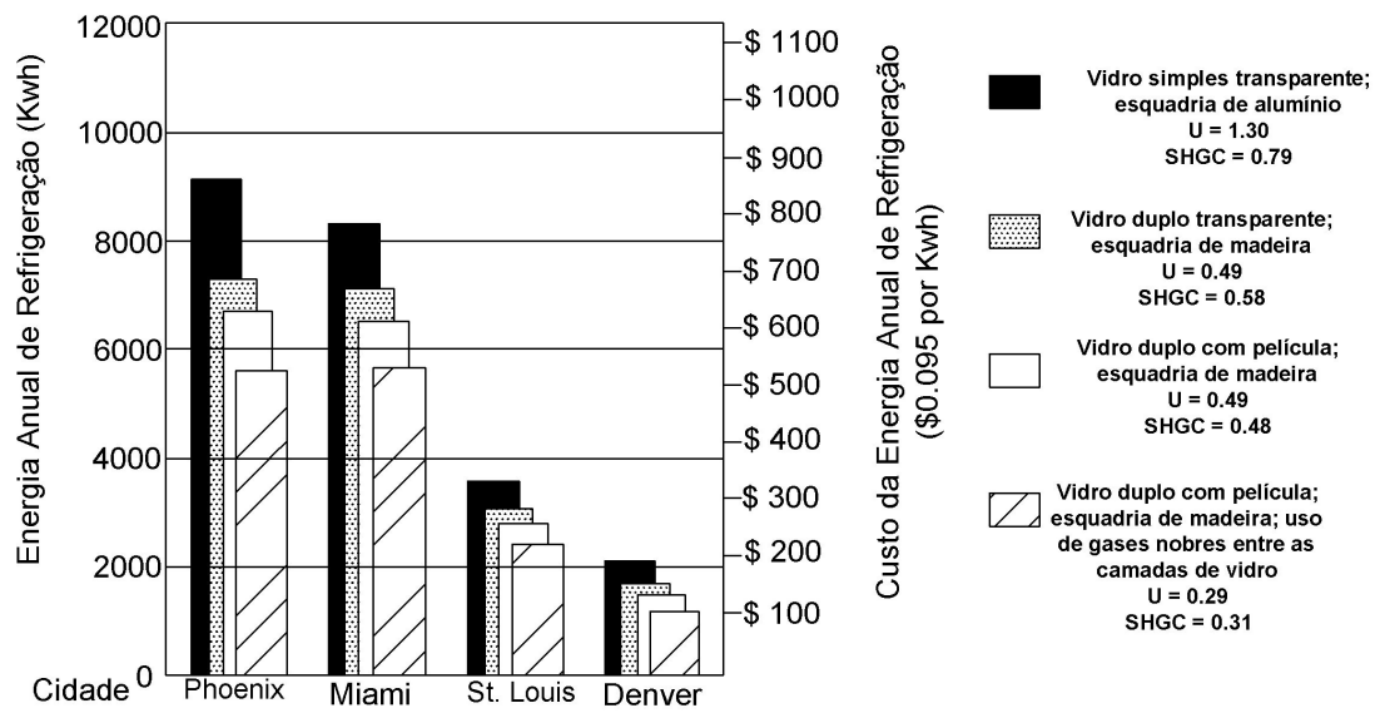

Figura 11 - Demanda energética para o resfriamento da edificação conforme o uso de diferentes tipos de janelas

Fonte:https://windows.lbl.gov/pub/selectingwindows/window.pdf, 2015

Em climas frios, janelas integram um alto isolamento térmico, microcâmaras de ar de baixa transmissividade e um detalhamento construtivo na sobreposição entre vidro e esquadria. Todos os diferentes componentes construtivos de uma janela são classificados individualmente de acordo com seu papel na eficiência energética. As janelas possuem diferentes categorias e podem ser classificadas segundo sua eficácia no controle do fluxo energético entre ambientes internos e externos (PHI, 2014).

Em climas quentes, a averiguação da relevância dos diferentes elementos componentes das janelas estão pendentes para certificação perante a normativa. 


\section{Estanqueidade ao Ar}

Infiltrações ou vazamentos de ar entre o ambiente interno e externo de uma edificação podem causar um significativo aumento na demanda de calefação/refrigeração do mesmo para atingir a qualidade de conforto térmico. Em ambientes frios, edificações pouco estanques, possuindo determinados pontos de escape de ar, podem desenvolver patologias em sua estrutura, pois, na medida que o vapor d'água penetra em seus orifícios de escape de ar, condensa-se intersticialmente. Em zonas afetadas pela poluição atmosférica, um edifício não estanque pode possuir uma redução dos níveis de qualidade do ar interior. Assim, uma edificação altamente estanque elimina ou reduz esses problemas (PHI, 2014).

A estanqueidade ao ar de uma edificação pode ser descrita como a ausência de infiltração de ar em suas vedações. A infiltração de ar faz parte das perdas energéticas não desejadas ou não controladas em edificações, possuindo um efeito negativo. Pode ser exemplificado pela criação de um fluxo de saída do ar quente no interior da edificação, no inverno, assim como a entrada de ar quente, no verão, causados por diferenciação de pressão entre os ambientes.

A eficiência da estanqueidade do ar é fundamental para a baixa demanda energética de uma construção, proporcionando economia energética, menores riscos de desenvolverem condensações de ar em suas superfícies, assim como a proteção acústica do meio externo.

A estanqueidade à passagem de ar pode ser confundida muitas vezes com a capacidade da edificação em respirar. De certa forma, janelas e outras aberturas devem ser a maneira de um edifício realizar a troca de fluxo energético com o meio externo, mas nunca através de suas vedações opacas, que podem causar patologias em sua estrutura, além de perdas energéticas não desejadas (WASSOUF, 2014).

Para aferir a estanqueidade à passagem de ar de uma construção, o teste blower door (Figura 12) é realizado, criando uma diferença de pressão no interior da edificação em relação ao seu exterior. Ele é preconizado pela normativa alemã EN-13829 (2001), possuindo um protocolo específico que deve ser seguido para atestar o alto nível de estanqueidade de uma residência.

O n50 é descrito como o fluxo de ar medido quando se cria um diferencial de pressão de 50 Pascal entre o ambiente interno e externo de uma edificação. 
Assim, as edificações seguindo a normativa devem possuir valores de n50 inferiores a $0,6 \mathrm{~m}^{3} / \mathrm{h}$, isto é, um volume máximo de trocas de ar entre o meio interno e externo referente a $60 \%$ durante o período de 1 hora, quando o diferencial de pressão entre os mesmos equivale a 50 Pa (PASSIVHAUS TRUST, 2014).

O Passive House Institute (2013) recomenda a realização do blower test em três fases distintas do projeto: a primeira, logo após a instalação da camada estanque ao ar, utilizando membranas com baixa permeabilidade à passagem de ar para vedar janelas e portas externas; a segunda, após a instalação das janelas e portas, comparando sua eficiência na resistência à passagem de ar; o terceiro e último blow test, realizado na fase final de execução da edificação, com seus devidos sistemas de ventilação implantados.

Os testes de estanqueidade ao ar devem possuir resultados semelhantes em suas diferentes fases de projeto. Os mesmos devem ser comparados, visando otimizar a remediação in loco na camada estanque ao ar caso haja diferenças de resultados no volume de ar trocado entre os meios (PHI, 2014).

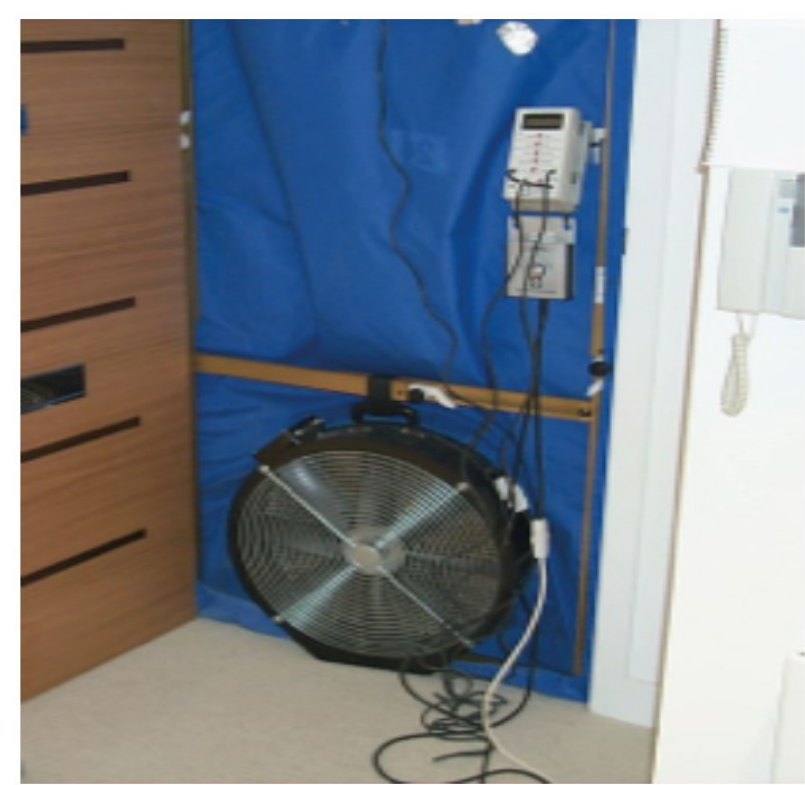

Figura 12 - Teste Blower door

Fonte:www.passivhaus.org.uk, 2015

Em climas frios, onde o controle à estanqueidade do ar faz parte de técnicas de construção bastante consolidadas, o mercado de materiais estanques ao ar e seus sistemas de integração entre os diferentes elementos construtivos (fitas, espumas, etc.) é bastante diversificado. Dentre os principais materiais estanques encontram-se as chapas de OSB, membranas em PVC e polipropileno. Em climas 
quentes, a estanqueidade ao ar na elaboração de uma edificação, apesar de sua redução da demanda energética por refrigeração, não possui valores de importância e impacto em equidade comparativamente às construções localizadas em climas frios. O mercado desta forma possui pouca variedade de produtos voltados para esse fim.

Assim como em outros conceitos, a estanqueidade do ar possui uma maior relevância em construções elaboradas em clima frio. Desta forma, análises do fluxo de energia térmica devem ser realizadas para aferir o real impacto da estanqueidade à passagem de ar no balanço energético nas edificações em clima quente (WASSOUF, 2014).

\section{2 \\ Controle de fluxos de ar}

A saúde e o conforto dos habitantes no interior de uma edificação são almejados como os principais objetivos dentre seus projetistas. Assim, uma excelente qualidade do ar torna-se indispensável. A qualidade do ar interno deve ser garantida por um sistema de ventilação eficiente, tornando o ambiente higiênico, devido às constantes trocas de ar com o meio externo, exaurindo possíveis contaminantes do mesmo.

Dentre as principais substâncias presentes no ar no interior de uma edificação encontram-se: gás carbônico, vapor de água, compostos orgânicos voláteis e odores humanos. Essas substâncias, em determinadas concentrações, podem causar efeitos prejudiciais à saúde dos habitantes do edifício, ou à sua própria estrutura.

Segundo ASHRAE (1989), o nível de $\mathrm{CO}_{2}$, presente em uma habitação não está ligado diretamente ao risco à saúde de seus habitantes, mas é considerado como um indicador de odores provenientes das atividades humanas e da sua tolerância para aceitação dos mesmos.

A água, em seu estado gasoso, é um material que, em altas concentrações, permite a proliferação de mofos e fungos nas superfícies internas das vedações térmicas. Não possuindo um sistema de ventilação eficiente, a umidade relativa da 
edificação pode superar valores que favorecem o surgimento desses organismos (CUNHA, 2008).

O princípio do sistema de ventilação, de uma forma geral, é garantir energia suficiente de calefação/refrigeração através do fluxo de ar, almejando a qualidade e o conforto interno da edificação, sem a real necessidade de sistemas ativos de energia.

Existem três formas de ventilação em uma edificação: a natural, a híbrida e a controlada de fluxo duplo, que serão explicadas a seguir. As construções localizadas em climas frios utilizam a ventilação controlada de fluxo duplo como regra, pois fazem uso do recuperador de calor, transferindo o calor do ar exaurido para o ar de entrada da edificação (PHI, 2014).

Poucos estudos foram realizados para quantificar a relevância da ventilação controlada de fluxo duplo como viés econômico e energético para edificações de clima quente. A análise dos diferentes tipos de ventilação em uma construção deve ser realizada para um maior aproveitamento energético e conforto térmico dos habitantes, objetivos esses preconizados pela norma.

\section{Ventilação Natural}

A ventilação natural pode ser analisada como uma importante forma de dissipação de calor em edificações localizadas em climas quentes com uma boa circulação de vento. Ela pode ser realizada de forma cruzada, devido a diferenças de pressão, ou de forma estratificada, baseada em diferenças verticais de temperatura. No verão, em climas quentes e secos, uma ventilação natural noturna é ideal para a dissipação do calor acumulado durante o dia, devido à considerável diminuição da temperatura do ambiente externo. A mesma situação pode possuir uma baixa eficiência em locais quentes e úmidos, decorrente da baixa variação de temperatura ao longo do dia (MARCARÓ, 1991).

A arquitetura passiva utiliza a ventilação natural em seus diferentes sistemas tradicionais para gerar correntes de ar no interior da edificação, trazendo o conforto climático em zonas quentes por convecção. Em ambientes quentes e secos, o sistema de refrigeração direta de um ambiente (refrigeração adiabática), pode ser utilizado para minimizar a carga de refrigeração da edificação (LENGEN, 2014). 
Apesar de todos os benefícios trazidos pelo sistema de ventilação natural na redução da demanda energética do ambiente interno, este possui seus limites. A forte dependência da existência de fluxos de vento com capacidade de resfriamento é uma limitação de construções que usam o sistema de ventilação natural como seu único meio de garantir o conforto térmico. Implica, muitas vezes, em efeitos negativos, como a ausência de corrente de ar capaz de resfriar o ambiente interno ou insuflar correntes de ar quente para a edificação, aumentando sua temperatura.

Outro agente limitador da eficiência de uma ventilação natural é a qualidade do ar, devido ao lançamento constante de poluentes atmosféricos, gerados pelo tráfego intenso de veículos e por grandes indústrias. À densidade dos prédios e o efeito das "ilhas de calor", também podem ser considerados agentes limitantes (PHI, 2013).

\section{Ventilação Híbrida}

Uma ventilação híbrida se situa como um sistema intermediário entre a ventilação natural e a ventilação controlada de fluxo duplo, mediante a exaustão de forma artificial do ar confinado em cômodos com possíveis odores e úmidos, como cozinha e banheiro. Da mesma forma que a ventilação natural, o fluxo de ar entra por determinadas aberturas naturalmente, e após circular no interior dos cômodos de uma residência, é exaurido artificialmente. Em construções localizadas em climas frios, o sistema de ventilação híbrido é pouco utilizado, sendo as aberturas passivas, no inverno, muitas vezes fechadas, por não possuírem mecanismos de recuperação de calor. Assim, o balanço energético da edificação pelo fluxo de ar híbrido é reduzido devido às perdas de energia térmica pela exaustão do ar quente e entrada do ar frio (PHI, 2013).

Edificações situadas em regiões de clima quente, possuindo um sistema de ventilação híbrido aliado a uma entrada contínua de ar natural, dispõem de uma melhoria na qualidade do ar interno. Essas edificações, contrariamente às localizadas em clima frio, não necessitam de um sistema de recuperação de calor em boa parte do ano, devido a temperaturas externas elevadas, muitas vezes superiores às do ambiente interno (WASSOUF, 2014). 
Assim, além de propiciarem uma exaustão do ar úmido interior, os exaustores retiram a energia térmica acumulada dos materiais construtivos, reduzindo a temperatura do ambiente.

\section{Ventilação de fluxo controlado duplo}

O sistema de ventilação de fluxo controlado duplo, considerado como o “pulmão das edificações Passivhaus" é utilizado como regra, em boa parte das construções centro-européias, possuindo sistemas de entradas e saídas mecânicas de ar (PASSIVHAUS TRUST, 2014).

Integrando um sistema de recuperação de calor e energia ou Heat and Energy Recovery Ventilation System (HERVS), a entrada do ar exterior é realizada de forma mecânica e direcionada para tubulações internas. A saída do ar úmido do interior da edificação, retirado por exaustores localizados em pontos estratégicos (banheiros, cozinha), é feita mecanicamente por tubulações internas. A tubulação do ar de entrada da edificação e do ar exaurido do mesmo se cruzam no sistema de recuperação de calor, não havendo contato físico direto entre ambos (Figura 13).

A energia térmica do ar de saída é recuperada através do sistema, devolvendo para o interior da habitação um ar aquecido e de melhor qualidade. Desta forma, no inverno, as edificações Passivhaus com fluxo controlado duplo de ventilação dispõem de um importante mecanismo de transferência de calor entre o ar interno e externo (PHI, 2014).

No verão, caso a temperatura interna seja inferior ao meio externo, há a possibilidade de se ativar um sistema de desvio, impedindo a entrada do excesso de calor na edificação. Essa transferência térmica é um dos princípios fundamentais para a baixa demanda energética de uma edificação energeticamente eficiente em clima frio, pois reduz a carga de calefação necessária, aquecendo o ambiente de forma passiva com fluxos cruzados de ar. 


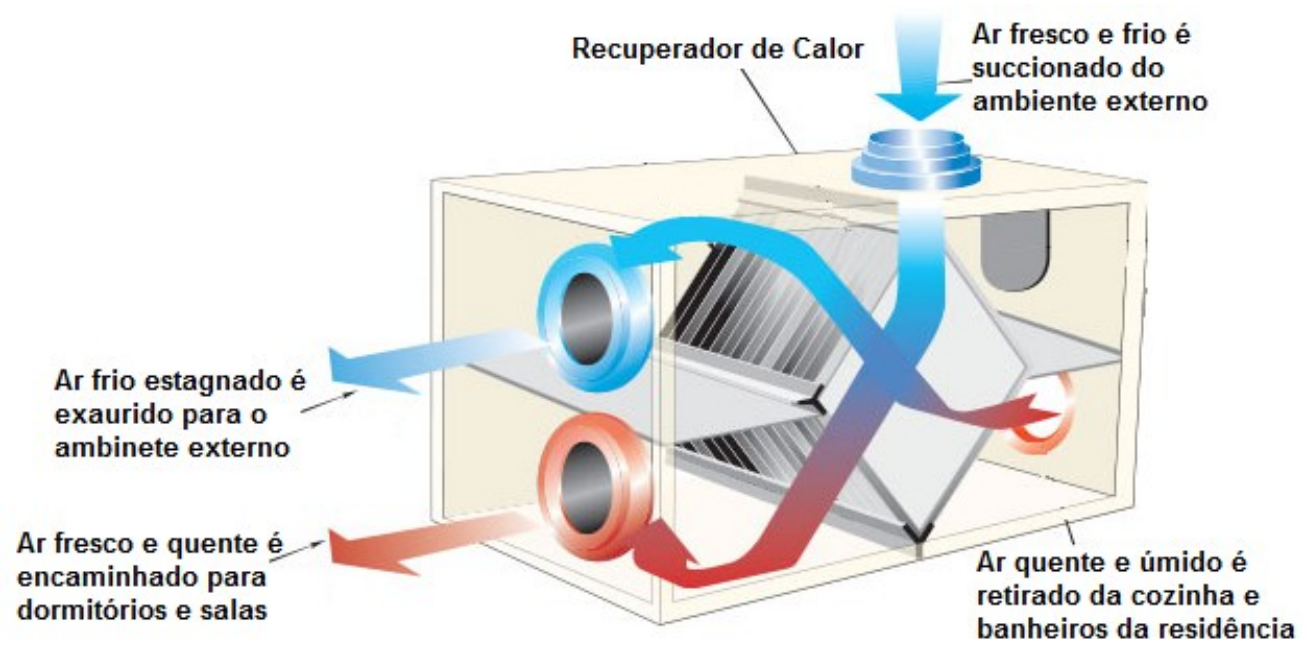

Figura 13 - Sistema de recuperação de calor Passivhaus

Segundo o Passive House Institute (2013), o controle do fluxo de ar e temperatura oferecidos pelo sistema de ventilação possuem uma ampla aceitação por seus usuários. A contínua troca de ar com o exterior sem a dependência direta das correntes de vento foi motivo para esse fato. $\mathrm{O}$ recuperador de calor, bem difundido no mercado, possui uma eficiência de 75-95 \% em sua recuperação. A eficiência obtida atinge baixas demandas energéticas e um alto padrão de conforto térmico da edificação (PASSIPEDIA, 2014).

Para evitar a entrada de partículas indesejadas e controlar a umidade interna, filtros são instalados nos dutos de entrada do ar exterior no sistema de ventilação. Para prevenir problemas de higiene, deve-se elaborar um sistema de controle e de limpeza dos filtros e dutos.

A intensidade do fluxo de ar de uma ventilação de conforto pode ser diferenciada segundo a necessidade da habitação. Fluxos mais altos de troca do ar podem ser acionados quando há muitas pessoas na edificação, quando se utiliza a cozinha ou quando se deseja refrescar a moradia no verão. Em contrapartida, um menor fluxo de troca de ar pode ser realizado quando não há usuários na edificação (PASSIVHAUS TRUST, 2014).

Segundo WASSOUF (2014, p.52), esse sistema de ventilação apresenta vantagens em relação aos demais quando encontramos determinadas condições: 
- $\quad$ Clima frio;

- $\quad$ Poluição sonora (tráfego, centros urbanos, etc.);

- Poluição atmosférica (áreas industriais, tráfegos, centros de aglomeração);

- $\quad$ Presença de pessoas alérgicas;

Em edificações Passivhaus, a alta estanqueidade ao ar das vedações garante um sistema de ventilação controlada de fluxo duplo eficiente, na medida em que não há vazamentos de ar nas suas vedações. Desta forma, todo o ar da edificação passa pelos filtros e recuperadores de energia, resultando em um alto nível de higiene e conforto em seu interior. O sistema de ventilação segue a seguinte regra: o volume de ar fresco e filtrado insuflado para o interior deve ser igual ao volume do ar exaurido. Esse equilíbrio de fluxos garante a eficiência do sistema de recuperação de energia das edificações em climas frios (PASSIPEDIA, 2014).

O resultado obtido com sistemas de ventilação de fluxo controlado duplo pelo Instituto é superior aos dos demais sistemas de ventilação, visto que a norma foi criada para atender inicialmente a uma redução da demanda energética quanto ao uso dos sistemas de calefação existentes. O trocador de calor acoplado ao sistema mostrou-se mais eficiente que os demais.

O baixo consumo energético da edificação resultou na busca em adotar os mesmos princípios para climas quentes, adequando-se os métodos e técnicas construtivas. Para a adaptabilidade em climas quentes, os sistemas de ventilação natural e híbrido devem ser analisados do ponto de vista energético e econômico.

\section{3}

\section{Critérios para certificação adaptados para climas quentes}

Os conceitos da arquitetura passiva aliada com as tendências modernas de construção descrevem uma receita para a eficiência energética de uma edificação. Apesar da certificação ser criada e desenvolvida inicialmente para atender à redução da demanda energética de uma edificação de clima frio, os resultados obtidos 
despertaram buscas para sua adaptação em climas quentes, com o propósito de atingir o mesmo objetivo.

As trocas térmicas na edificação para o conforto do ambiente interno são idealizadas através do sistema de ventilação de fluxo duplo, porém não é vedada a utilização de sistemas de refrigeração ou calefação convencionais.

Para atingir seus objetivos, o projeto da edificação deve ser dimensionado com a ferramenta adequada, o PHPP, para a certificação perante o Instituto. Para a certificação da edificação, definiram-se temperaturas de conforto interno no verão inferiores a $25{ }^{\circ} \mathrm{C}$ e, no inverno, superiores a $20^{\circ} \mathrm{C}$ (PHI, 2013). O PHPP é alimentado com dados do projeto, resultando em análises quanto a: demanda anual de calefação/refrigeração, consumo anual de energia primária, estanqueidade ao ar, taxa de superaquecimento da estrutura, e etc., critérios esses que devem ser comparados com os valores máximos permitidos na norma.

Caso os valores projetados ultrapassem os valores requeridos, o projeto é modificado para atender aos critérios básicos estabelecidos. Salienta-se que os limites estipulados pela normativa são para climas temperados. Assim, estudos devem ser realizados para aferir a veracidade dos mesmos em climas tropicais.

A descrição detalhada dos critérios diretos e indiretos para a certificação foi adaptada para climas quentes, onde não há demanda anual energética para sistemas de calefação, sendo adotados os mesmos parâmetros limites para os sistemas de refrigeração.

\subsection{1 \\ Critérios diretos}

\section{Consumo anual de energia primária $\leq 120 \mathrm{kwh} / \mathrm{m}^{2}$.ano}

O valor real do consumo de energia inclui perdas em sua geração, transformação e distribuição. Assim, seus valores dependem do tipo de energia utilizada. A energia primária representa o real valor energético gasto com componentes mecânicos, sistemas ativos de refrigeração ou calefação, aquecimento de água, iluminação, eletrodomésticos, equipamentos de comunicação, entre outros. A norma estabelece o valor máximo de $120 \mathrm{kwh} / \mathrm{m}^{2}$ para o consumo anual de energia pri- 
mária. Esse critério, criado pela Passive House Institute, busca, além da redução da demanda energética total de uma edificação, a alta eficiência dos produtos que consomem energia.

\section{Demanda anual de energia para calefação/refrigeração $\leq 15$ $\mathrm{kwh} / \mathrm{m}^{2}$.ano}

Se estabelece como critério direto para certificação a demanda energética máxima de $15 \mathrm{kwh} / \mathrm{m}^{2}$.ano a ser retirada/fornecida a edificação para a mesma se adequar aos padrões de temperatura e umidade impostos pela normativa, sendo conferida através do programa PHPP. Esse valor empírico corresponde à energia para calefação/climatização requerida pela edificação, na manutenção da temperatura em $20^{\circ} \mathrm{C}$ no inverno e $25^{\circ} \mathrm{C}$ no verão.

\section{Estanqueidade ao ar $\mathrm{N} 50 \leq 0,6 \mathrm{~m}^{3} / \mathrm{h}$}

Como descrito anteriormente, o critério de estanqueidade ao ar de uma edificação estabelece valores inferiores a $60 \%$ de troca de volume do ar entre os meios internos e externos, durante o período de 1 hora, quando o diferencial de pressão entre eles situa-se em $50 \mathrm{~Pa}\left(\mathrm{~N} 50 \leq 0,6 \mathrm{~m}^{3} / \mathrm{h}\right)$.

\subsection{2}

\section{Critérios indiretos}

Frequência de temperatura abaixo/acima dos limites mínimos e máximos

Em climas quentes, a temperatura interna de uma edificação certificada não pode ultrapassar temperaturas superiores a $25{ }^{\circ} \mathrm{C}$ durante $10 \%$ do seu tempo de uso. O cálculo para esse valor é realizado pela ferramenta PHPP, sendo controlado por meio de conceitos passivos da arquitetura. A ferramenta interpreta o cálculo do tempo em que a temperatura da residência supera o valor de $25{ }^{\circ} \mathrm{C}$ em relação a 
média das temperaturas excessivas de todo o edifício, considerando-o em uma zona única (a pior situação).

\section{Excesso de umidade}

Deve-se evitar o surgimento de mofos (umidade relativa interna $\geq 80 \%$ ) na edificação, assim como condensações superficiais sobre os vidros, garantindo a qualidade de higiene (PHI, 2013). A normativa estabelece uma umidade relativa máxima de $75 \%$ na edificação.

Esse critério indireto é atendido utilizando vedações de baixa transmissividade térmica. Caso se faça uso de materiais com essas propriedades, recomendamse análises em programas de cálculo específicos para garantir a qualidade higiênica do ambiente.

A tabela 5 foi elaborada no intuito de resumir os principais critérios diretos e indiretos para a certificação.

Tabela 5 - Resumo dos critérios para certificação adaptados para climas quentes

\begin{tabular}{|c|c|}
\hline \multicolumn{2}{|c|}{ Critérios diretos } \\
\hline Consumo anual de energia primária & $120 \mathrm{kwh} / \mathrm{m}^{2}$.ano \\
\hline $\begin{array}{l}\text { Demanda anual de energia para calefa- } \\
\text { ção/refrigeração }\end{array}$ & $15 \mathrm{kwh} / \mathrm{m}^{2}$. ano \\
\hline Estanqueidade ao ar & $\mathrm{N} 50 \leq 0,6 \mathrm{~m}^{3} / \mathrm{h}$ \\
\hline \multicolumn{2}{|c|}{ Critérios indiretos } \\
\hline $\begin{array}{l}\text { Frequência de Temperatura acima/abaixo dos } \\
\text { limites mínimos e máximos }\end{array}$ & $\begin{array}{l}\text { Limites de temperatura de } 20{ }^{\circ} \mathrm{C} \text { no inverno e } \\
25{ }^{\circ} \mathrm{C} \text { no verão. Os limites não devem ser ul- } \\
\text { trapassados em } 10 \% \text { do tempo de uso da edifi- } \\
\text { cação ao longo do ano }\end{array}$ \\
\hline Excesso de umidade & $\begin{array}{l}\text { Umidade relativa limite de } 75 \% \text { ao ano. O } \\
\text { limite não deve ser ultrapassado em } 10 \% \text { do } \\
\text { tempo de uso da edificação ao longo do ano }\end{array}$ \\
\hline
\end{tabular}

Fonte: PHI, 2015. (Adaptada).

\section{4}

\section{Da arquitetura passiva à Passivhaus}

A normativa se destaca pelo desenvolvimento da arquitetura passiva, utilizando materiais construtivos e modificações do arranjo da edificação para validar a redução do consumo energético. $\mathrm{O}$ avanço da arquitetura passiva com a padroni- 
zação de métodos e critérios a serem seguidos promove o desenvolvendo de edificações mais eficientes.

A Tabela 6 foi elaborada no intuito de demonstrar os critérios da arquitetura passiva à solução Passivhaus encontrada, contornando suas limitações.

Tabela 6 - Solução Passivhaus para a arquitetura passiva

\begin{tabular}{cc}
\hline $\begin{array}{c}\text { Arquitetura passiva con- } \\
\text { vencional }\end{array}$ & \multicolumn{1}{c}{ Arquitetura Passivhaus } \\
\hline Critérios & Solução \\
\hline Orientação Solar & $\begin{array}{c}\text { Vedações térmicas eficientes } \\
\text { Possibilita uma maior área em fachadas onde o } \\
\text { balanço energético seria ineficiente }\end{array}$ \\
\hline Impacto do vento & $\begin{array}{c}\text { Edificações altamente estanques ao ar } \\
\text { Impossibilita o fluxo de ar através das veda- } \\
\text { ções opacas }\end{array}$ \\
\hline Uso do sombreamento (fixo ou móvel) \\
Reduz a incidência de radiação no interior da \\
edificação
\end{tabular}

Para a certificação, todos os projetos devem ser compilados utilizando o programa PHPP. Seu uso é essencial para que os dados obtidos através da modelagem arquitetônica sejam comprovados na forma de resultados.

\section{5}

\section{O programa Passive House Planning Package}

O PHPP, ferramenta utilizada para projetar edificações, consiste em um programa de desenvolvimento dentro de uma planilha Office, onde simulações termodinâmicas são realizadas através de valores nele imputados. Áreas da superfície da residência, condições meteorológicas, sistemas de ventilação, sombreamento, janelas, demanda de resfriamento e demanda de calefação fazem parte da ferramenta.

A Figura 14 a seguir foi retirada do programa, que analisa o balanço energético da edificação quanto aos critérios passivos para sua devida certificação. 


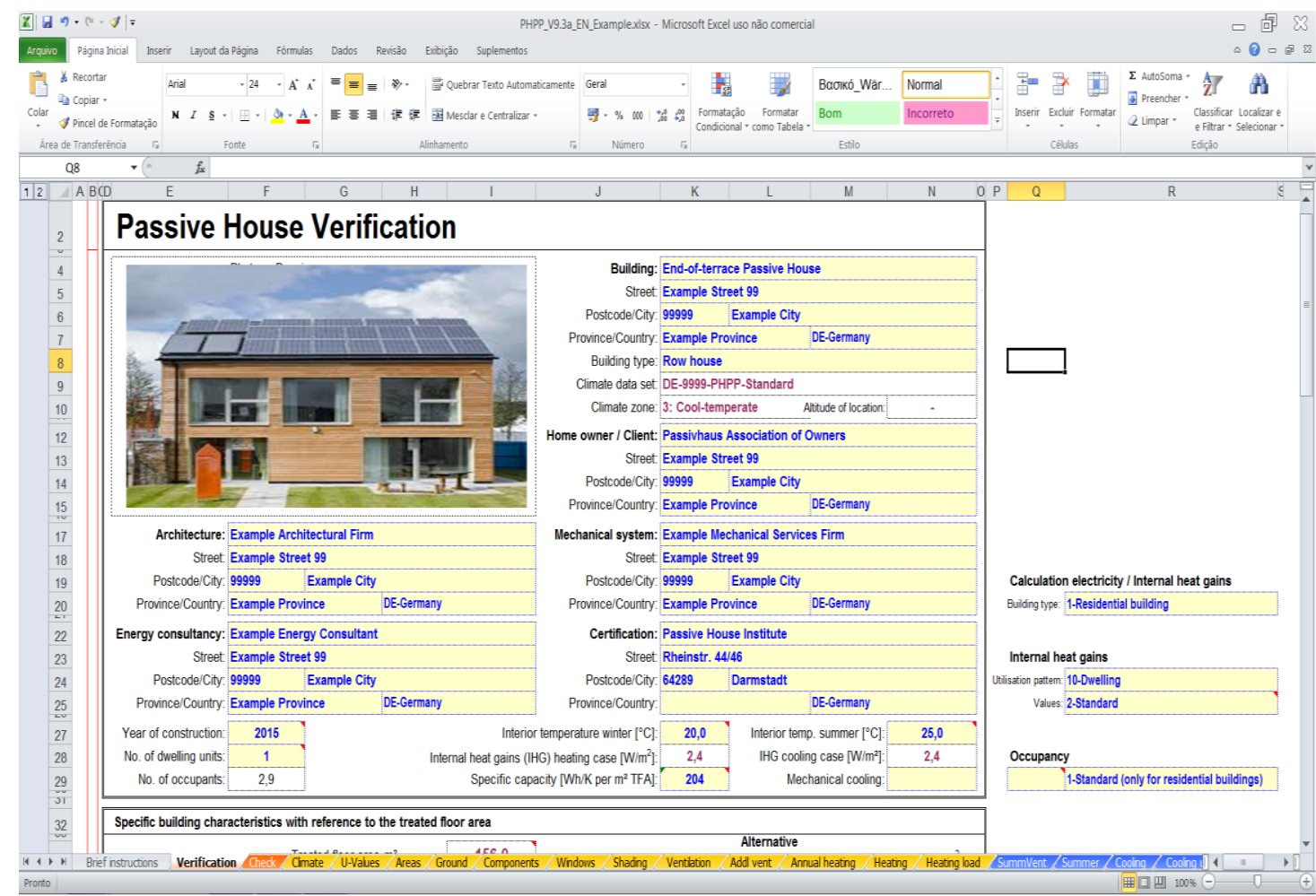

Figura 14 - Residência Passivhaus analisada pelo programa Passive House Planning Package

O funcionamento da ferramenta, em sua forma user-friendly, é de fácil acesso, voltado para arquitetos e engenheiros no ramo de edificações. Através de formulações termodinâmicas, dados de Output fornecem de forma objetiva os resultados da edificação modelada, além de compara-los aos critérios estabelecidos. Os valores de saída são classificados com relação ao cumprimento ou não de seus requisitos. 


\section{5. \\ Sistema de resfriamento por absorção}

Até o presente momento, o mercado de climatizadores de ambiente está tomado pelos sistemas refrigeradores por compressão de refrigerantes. Exemplos deste são encontrados em condicionadores de ar, geladeiras, freezers etc. Seu ciclo para a produção de frio necessita exclusivamente de uma alimentação elétrica para o uso do compressor, circulando fluidos refrigerantes.

No intuito de utilizar sistemas de climatização do ambiente por vias sustentáveis e proporcionar a redução do uso de energia elétrica provinda da rede de abastecimento convencional, propôs-se uma tecnologia de resfriamento utilizando painéis solares para sua alimentação. $\mathrm{O}$ resfriamento por absorção, tecnologia primariamente utilizada, porém atualmente pouco empregada, devido à maior facilidade do resfriamento por compressão, foi avaliada para integrar o sistema de refrigeração.

\section{1 \\ Origem}

Segundo FOLEY (2000), os sistemas de resfriamento por absorção foram criados por Carré em 1850, utilizando água e ácido sulfúrico. Posteriormente em 1860, utilizando em seu sistema amônia e água, o sistema de resfriamento por absorção foi comercializado.

O circuito de resfriamento por absorção se assemelha ao circuito por compressão de vapor, ambos possuindo em seu sistema compartimentos de condensação e evaporação. Integram-se ao circuito de resfriamento por absorção os compartimentos chamados de "gerador" e "evaporador", sendo exclusivos desse tipo de resfriamento.

O ciclo de resfriamento por compressão é conceituado como um ciclo operado a trabalho, pois esse só é realizado quando se faz uso de um compressor, desprendendo trabalho para essa tarefa. Já quanto ao ciclo de 
resfriamento por absorção, é referido como um ciclo operado a calor, pois se faz uso da energia térmica para seu funcionamento. $\mathrm{O}$ compartimento gerador e evaporador, presentes exclusivamente no ciclo de resfriamento por absorção, fazem com que não haja a real necessidade mecânica do compressor para que o resfriamento seja efetivo (SBRAVATI, 2005).

$\mathrm{O}$ coeficiente de performance (COP), fruto das disparidades entre os sistemas de resfriamento por absorção e compressão, representa a relação entre a energia térmica fornecida pela bomba de calor e a energia elétrica consumida pelo sistema. Os sistemas de resfriamento por absorção possuem COP inferiores aos sistemas que utilizam compressores alimentados por energia elétrica, entre 0,5 a 1,7 e superiores a 3,0, respectivamente (EICKER, 2009).

Apesar do menor desempenho do coeficiente de performance dos sistemas de absorção, ambos os ciclos podem ser definidos diferenciadamente. A energia requerida para realizar o ciclo à compressão é utilizada na forma de trabalho, energia essa mais valiosa e cara em comparação a energia termal, utilizada pelo ciclo de absorção.

O primeiro modelo de uso doméstico do ciclo de absorção fabricado no Brasil é datado de 1950, onde iniciou-se a venda de geladeiras a querosene (CONSUL, 2015). A energia fornecida para o funcionamento do sistema era provinda através da combustão do querosene, evaporando uma solução de amônia diluída em água no gerador, iniciando o ciclo de resfriamento (Figura 15).

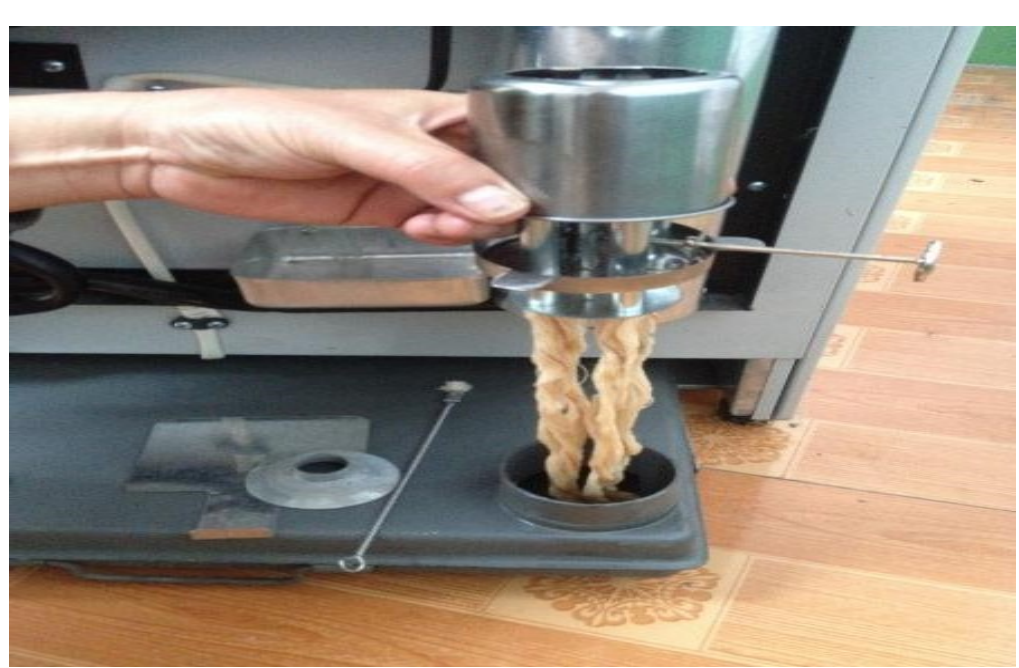

Figura 15 - Geladeira por ciclo de absorção alimentada por querosene Fonte: http://www.cnglacier.com. 2015 
Apesar do uso de amônia em seu sistema, que é uma substância nociva à saúde humana em altas concentrações, a utilização dos refrigeradores por absorção foram de grande importância para a conservação de alimentos e climatização do ambiente interno de infraestruturas e casas, onde o sistema de energia elétrica derivado da concessionária não era fornecido.

O sistema de resfriamento por absorção foi caindo em desuso conforme o invento do resfriamento por compressão, aliado ao avanço dos sistemas de distribuição de energia elétrica pelo país. A praticidade de sistemas de resfriamento integrados ao sistema elétrico residencial dispensou o uso de energias secundárias, que necessitam de manutenção e cuidados especiais.

\section{2}

\section{Ciclo de resfriamento por absorção utilizando $\mathrm{BrLi}$}

Os sistemas de resfriamento por absorção modernos utilizam água como fluido refrigerante e Brometo de Lítio (BrLi) como fluido absorvedor. Seu antecessor fazia uso de uma solução de Amônia $\left(\mathrm{NH}_{3}\right)$ como refrigerante e água como composto absorvedor (ASHRAE, 2009).

Devido à inexistência de compressores para seu funcionamento, o sistema de resfriamento por absorção deve possuir um diferencial de pressão em seus compartimentos capaz de circular o fluido refrigerante sem que haja compressão mecânica. Assim, o fluido absorvedor, por possuir uma forte afinidade pelo refrigerante, possui um papel fundamental de manter o diferencial de pressão nos compartimentos que compõem o sistema de resfriamento.

Segundo KUREM \& HORUZ (2001), os sistemas de resfriamento por absorção compostos de Água/Brometo de Lítio possuem um maior rendimento energético, são mais seguros e possuem uma maior afinidade do absorvente pelo refrigerante, em comparação aos sistemas compostos por Amônia/Água. No entanto, eles possuem como desvantagens, temperaturas para climatização superiores e possibilidade de cristalização do Brometo de Lítio em seus compartimentos.

Seu funcionamento se faz através de diferenciais de pressão entre seus compartimentos, operando a pressões mais altas no gerador e condensador, e a pressões mais baixas no absorvedor e evaporador. O calor introduzido no sistema pos- 
sibilita a separação do refrigerante (água) e do fluido absorvente (Brometo de Lítio), que são atraídos física e quimicamente, desta forma resultando na elevação da pressão do refrigerante, sendo um processo análogo ao sistema produzido por compressão elétrica (YASAKI, 2007).

O ciclo é separado devidamente em dois compartimentos com pressões diferentes. O compartimento superior corresponde ao gerador e ao condensador, que possuem pressões a médio vácuo. O compartimento inferior é representado pelo absorvedor e evaporador, que possuem pressões inferiores ao compartimento superior.

A Figura 16 representa um ciclo de absorção moderno. Fontes de energia térmica como querosene e gás natural ainda são utilizadas para alimentação desses sistemas.

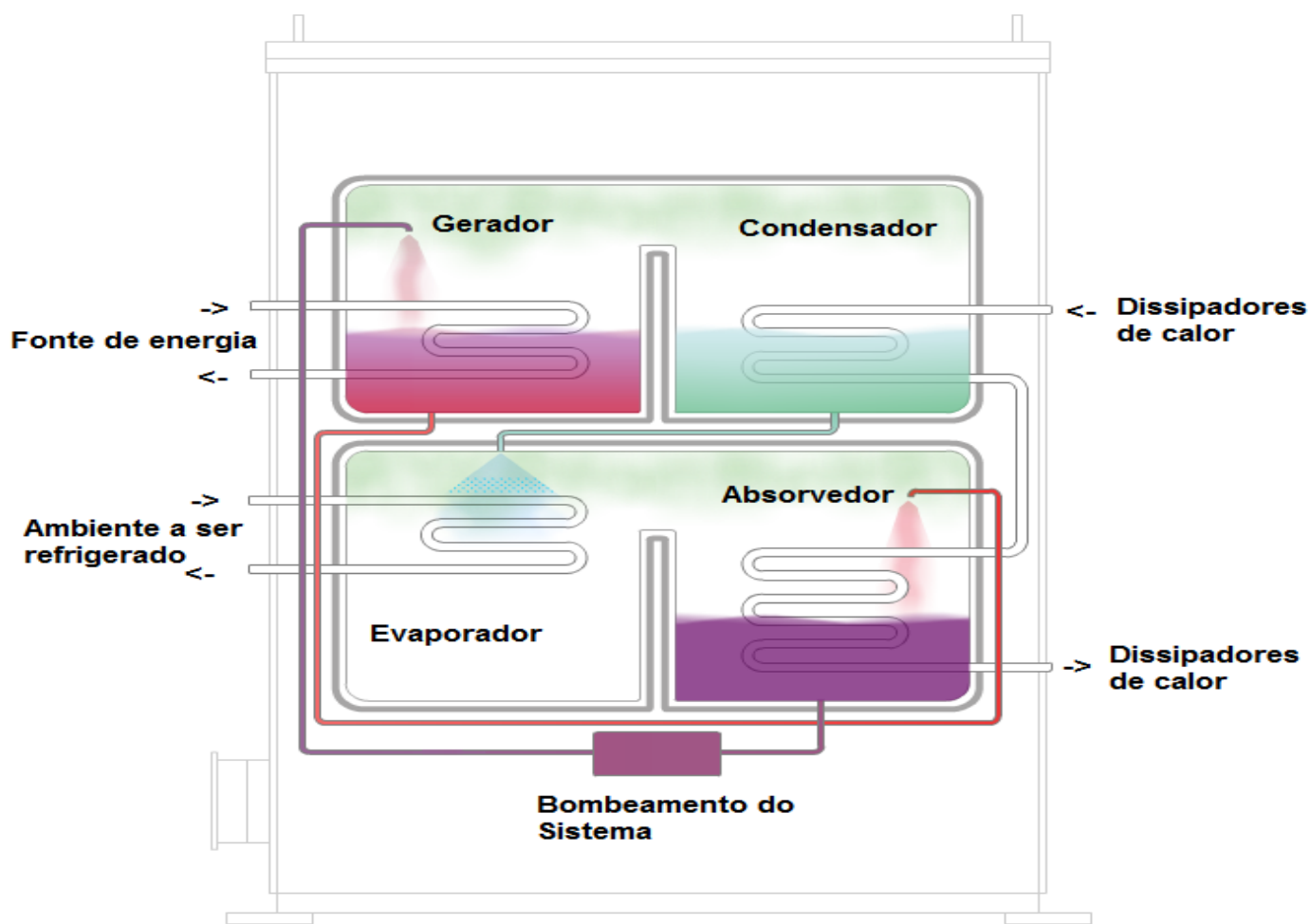

Figura 16 - Sistema de resfriamento por absorção utilizando Brometo de Lítio Fonte: YAZAKI, 2007 (Modificado)

O ciclo de resfriamento inicia com uma fonte de calor aquecendo a solução de Brometo de Lítio diluída em água. Quando o compartimento gerador recebe uma certa quantidade de energia, a água da solução diluída de Brometo de Lítio evapora sob condições de pressão a médio vácuo, a temperaturas inferiores a $100{ }^{\circ} \mathrm{C}$, encaminhando, assim, o vapor do refrigerante para o separador primário. 
O fluido absorvedor (Brometo de Lítio), agora concentrado, é então encaminhado para o compartimento absorvedor (YASAKI, 2007).

$\mathrm{O}$ vapor do refrigerante em temperaturas elevadas flui através do condensador, sendo resfriado até sua temperatura de condensação por um trocador de calor. Em seu estado líquido, a solução de água acumulada no condensador passa através de uma tubulação estreita, rumo ao evaporador.

O líquido refrigerante no evaporador é exposto a condições de pressão inferiores em relação aos compartimentos superiores e, devido à influência do fluido concentrado altamente higroscópico (Brometo de Lítio), presente no compartimento do absorvedor, o líquido refrigerante evapora em temperaturas relativamente baixas, resfriando o ambiente em contato com o mesmo.

O refrigerante presente no evaporador, em seu atual estado gasoso, é então atraído pelo fluido concentrado de Brometo de Lítio presente no absorvedor, gerando calor em sua reação.

Assim como no condensador, o calor produzido no absorvedor nas reações presentes em seu compartimento interior deve ser dissipado/removido através de trocadores de calor.

O fluido resultante no absorvedor, uma solução diluída de Brometo de Lítio, é bombeada novamente para o gerador, reiniciando o processo do resfriamento (YASAKI, 2007).

Algumas observações podem ser feitas nos sistemas atuais de resfriamento por absorção. O processo descrito anteriormente produz o resfriamento do ambiente com a ebulição de uma solução, devido ao ganho de energia (YASAKI, 2007). Desta forma, uma fonte de calor deve ser fornecida para que a solução atinja essas temperaturas, iniciando o ciclo.

Os trocadores de calor, presentes em diversos pontos do sistema, são normalmente alimentados por energia elétrica para seu devido funcionamento. Faz-se uso da energia elétrica para o bombeamento da solução de Brometo de Lítio presente do absorvedor, retornando-a ao gerador. O consumo de energia elétrica total de um sistema de resfriamento por absorção corresponde a cerca de 5-10 \% da energia gasta por compressores da mesma capacidade de resfriamento (MADEF, 2003).

A possibilidade quanto ao uso de uma fonte de energia renovável para alimentar o ciclo de resfriamento por absorção de Brometo de Lítio resultou em uma 
pesquisa quanto à conversão da energia solar em energia térmica. Sendo assim, uma análise da disponibilidade energética do sol e dos equipamentos existentes no mercado elaborados para o aproveitamento da energia foram pesquisados.

\section{3 O uso da energia solar para o abastecimento do refrigerador por ab- sorção}

O sol pode ser explicado como um reator a fusão, onde o elemento hidrogênio se converte em hélio continuamente. $\mathrm{O}$ total de energia emitida pelo sol durante o período de 1 hora é 3,8 x 1020 Mega-Watts, equivalente a $63 \mathrm{MW} / \mathrm{m}^{2}$ em energia referente à superfície do sol. A Terra recebe uma fração ínfima dessa energia emitida, igual a 1,74 x $1011 \mathrm{MW}$ (equivalente a $341 \mathrm{~W} / \mathrm{m}^{2}$ de superfície da Terra). Apesar dessa reduzida fração, é estimado que 84 minutos de radiação solar possa satisfazer a demanda energética mundial da Terra durante o período de um ano (MUHHAMMAD, 2001).

A magnitude da energia solar incidente em um determinado local na Terra é diretamente dependente de três fatores:

- $\quad$ Latitude e Longitude;

- $\quad$ Hora do Dia;

- $\quad$ Calendário.

A energia solar pode ser convertida em energia química, elétrica e térmica. A conversão de energia solar em energia elétrica pode ser realizada através de painéis fotovoltaicos. A energia elétrica proveniente da radiação solar está cada vez mais sendo desenvolvida e implantada no mercado, possuindo menores custos e melhor desempenho ao longo dos anos. O armazenamento do excesso de energia elétrica produzida pode ser realizado através de baterias instaladas ao sistema.

A conversão da radiação proveniente do sol em energia térmica pode ser utilizada de forma direta para aquecer/resfriar um ambiente (através dos critérios da arquitetura passiva), ou de forma indireta, através de coletores solares, gerando água quente ou vapor. 
Os coletores solares responsáveis pela conversão da energia solar em energia térmica são denominados trocadores de calor. Eles absorvem a radiação solar, transformando-a em calor e transferindo a um determinando fluido (água, óleo). A energia coletada pode ser utilizada diretamente na edificação ou armazenada em tanques, com isolamento térmico apropriado para uso posterior, principalmente em períodos noturnos onde não há irradiação solar (YASAKI, 2007).

Existem dois tipos de coletores solares presentes no mercado: os coletores com concentração e os sem concentração.

Os coletores concentradores (Figura 17) consistem em uma grande superfície côncava refletora, concentrando os raios solares em uma pequena área determinada do coletor, convergindo seu fluxo de radiação nesse ponto. Esse tipo de coletor pode gerar temperaturas superiores aos coletores sem concentração.

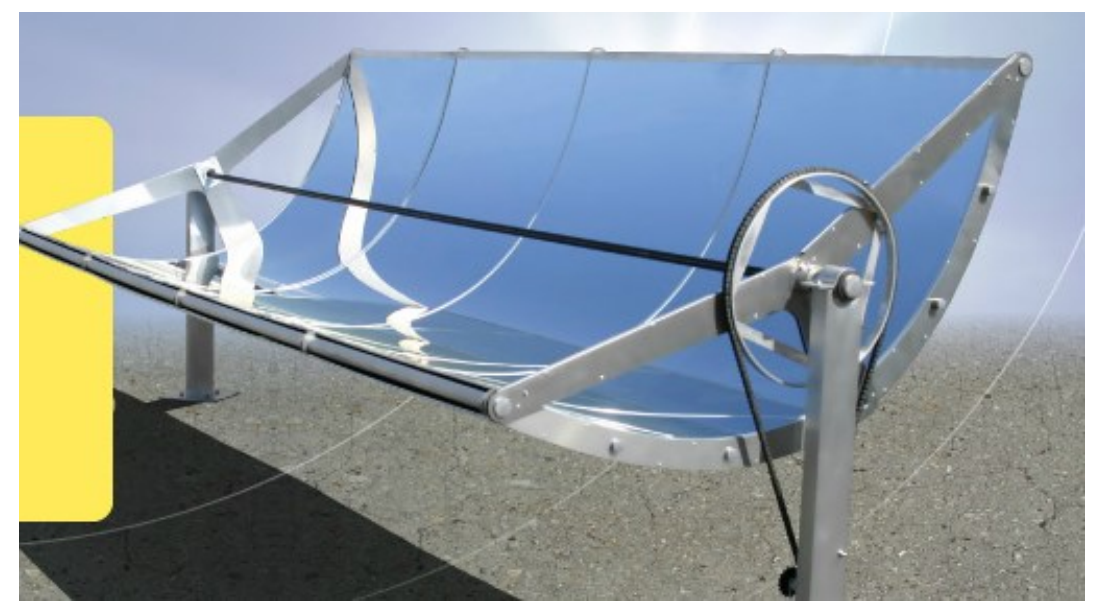

Figura 17 - Coletores concentradores Fonte: www.solarpowerworldonline.com, 2015

Os coletores sem concentração são os mais utilizados no mercado, por possuírem uma maior facilidade em sua implantação nas áreas residenciais e reduzido custo, apesar de fornecerem temperaturas inferiores aos coletores concentradores (MUHHAMMAD, 2001) consistem em áreas fixas que interceptam e absorvem a radiação solar, convertendo-a em calor (Figura 18). Nesse tipo de coletor, o painel solar como um todo absorve a energia proveniente do sol. Os coletores a vácuo e de placa lisa são exemplos de coletores não concentradores. 


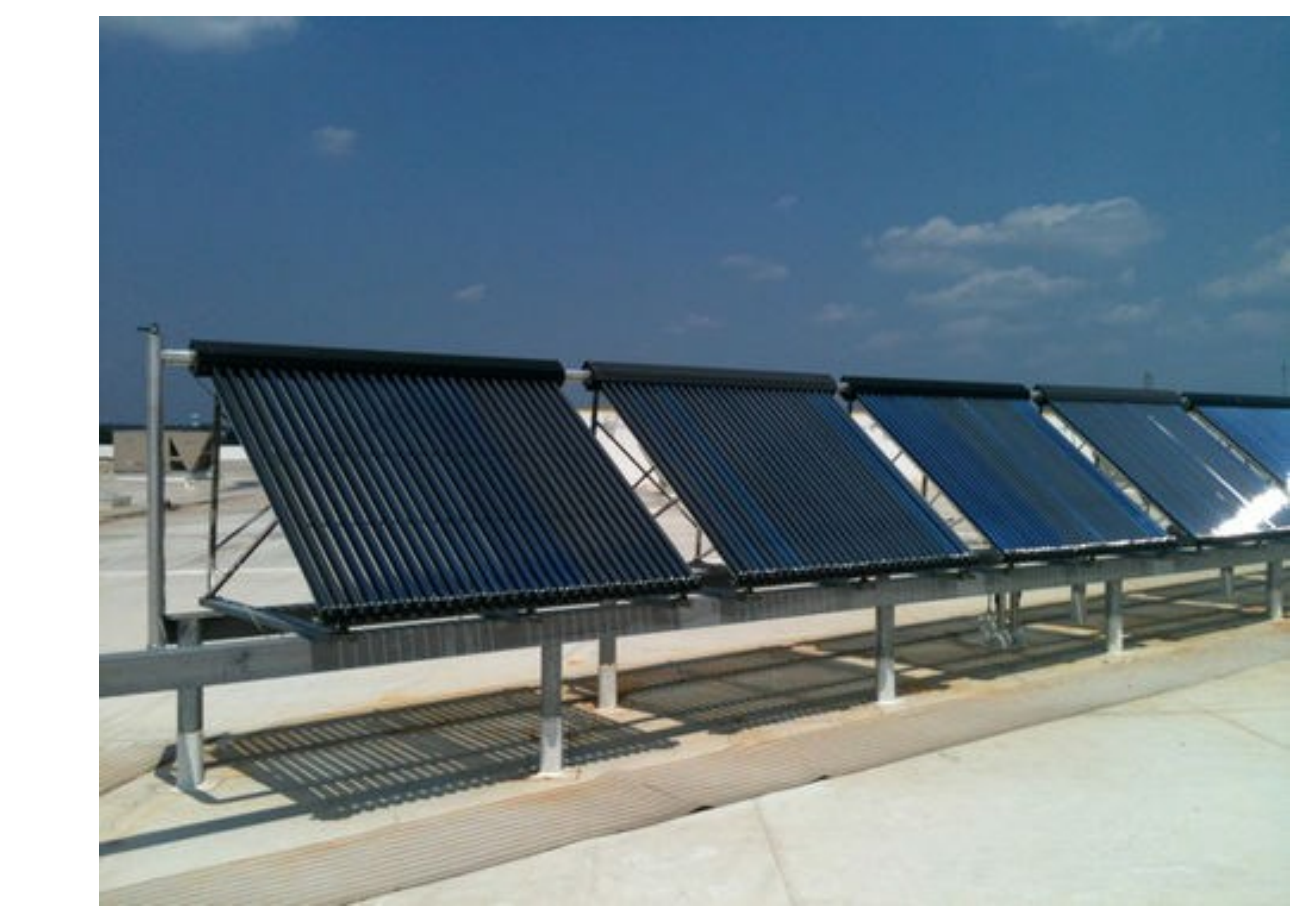

Figura 18 - Coletores não concentradores planos Fonte:www.archiexpo.com, 2015

Devido ao contínuo avanço tecnológico dos coletores solares térmicos, acoplou-se o equipamento de resfriamento por absorção para ser alimentado através de painéis solares. O sistema se tornou possível graças ao contínuo avanço da eficiência dos coletores na conversão de energia solar em térmica. Outras fontes de energia, como querosene ou gás natural, podem ser também utilizadas como segunda opção, caso não haja energia térmica proveniente do sol suficiente para alimentação do sistema de resfriamento.

A escolha do tipo de coletor solar se deve à sua fácil instalação, custo reduzido e ao seu fornecimento de energia suficiente para iniciar o ciclo de resfriamento por absorção. A Figura 19 ilustra o sistema de resfriamento analisado sendo alimentado por painéis solares térmicos. 


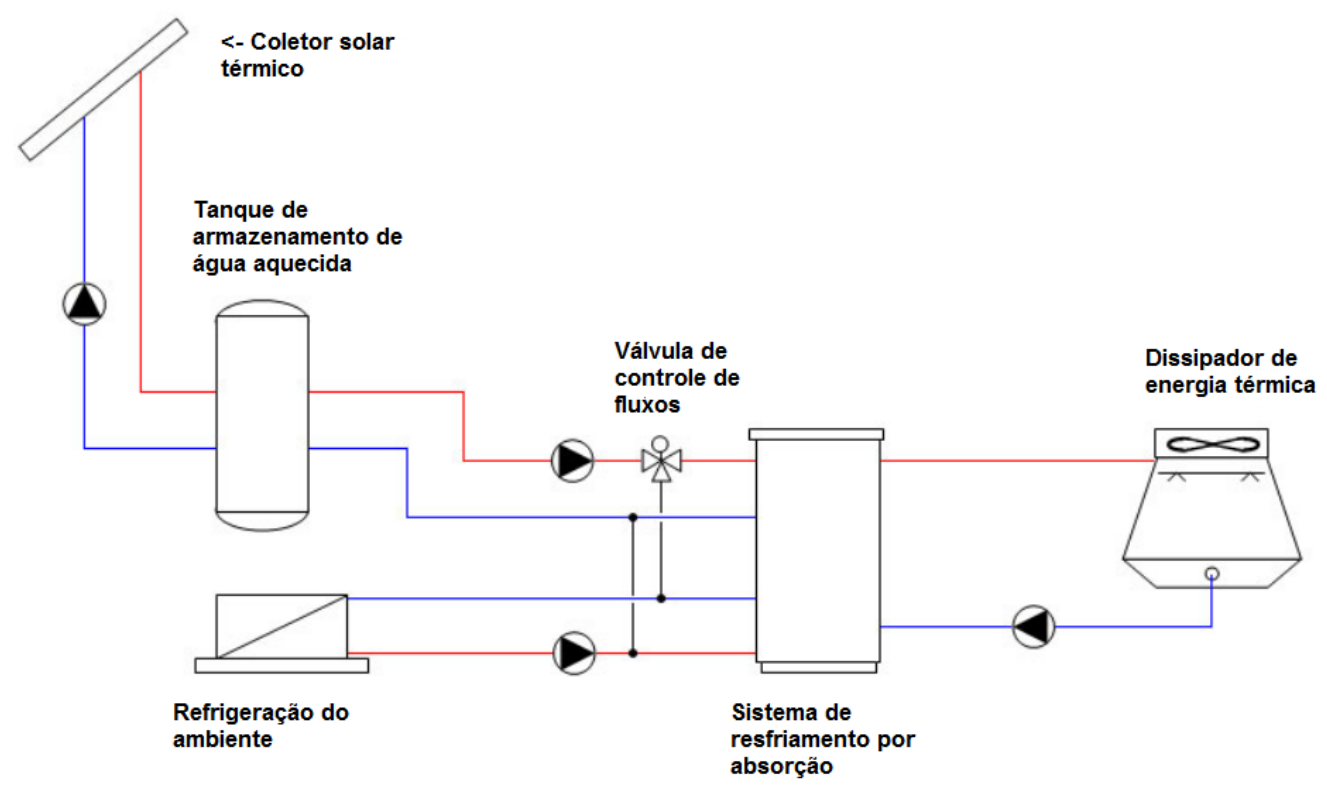

Figura 19 - Sistema de resfriamento por absorção alimentado por painéis solares Fonte: YASAKI, 2007 (Modificado)

No sistema, um tanque com isolamento térmico em relação ao seu exterior é utilizado para armazenar a água aquecida nos painéis solares. A água armazenada no tanque é então encaminhada ao compartimento gerador do sistema de absorção. O calor armazenado na água, proveniente dos painéis solares, é transferido à solução diluída de Brometo de Lítio, iniciando o ciclo de resfriamento. Após a perda de sua energia térmica, a água é reencaminhada ao tanque de isolamento térmico, circulando novamente através dos coletores solares.

Um circuito de água é introduzido no compartimento de evaporação do sistema de resfriamento. Esse circuito absorve o calor dos cômodos da residência, refrigerando o ambiente. O fluido que circula pelos cômodos da edificação, agora aquecido, é reencaminhado ao evaporador e novamente refrigerado, reiniciando o processo de climatização. A alimentação energética do motor para que tenhamos fluxo de água deve ser feita por energia elétrica.

Trocadores de calor, presentes no condensador e absorvedor, são responsáveis pela redução da temperatura do refrigerante ao seu ponto de condensação e pelo aumento da afinidade do Brometo de Lítio concentrado com o refrigerante, respectivamente. 


\section{6. \\ Estudo de caso}

Até o presente momento do trabalho foram descritos referenciais teóricos sobre:

- $\quad$ As certificações ambientais vigentes no mercado;

- $\quad$ As normas de construção;

- $\quad$ Considerações sobre arquitetura passiva;

- $\quad$ Arquitetura Passivhaus e seus critérios para certificação;

- $\quad$ Análise do sistema de resfriamento por absorção existente no mercado.

A metodologia de pesquisa utilizada no trabalho possui um caráter exploratório, objetivando analisar os critérios e metodologias Passivhaus de construção utilizados em climas frios, adaptando-os a climas quentes. Como forma de análise quantitativa, utilizou-se a ferramenta de cálculo PHPP descrita anteriormente. Outro fator de cunho exploratório foi o estudo dos sistemas de resfriamento por absorção abastecido por energia térmica, tecnologia essa anteriormente difundida no Brasil. Acreditou-se que a união de uma metodologia de construção passiva, auxiliada ao uso da energia solar para a climatização de edificações, possa levar à existência de edificações de baixo consumo energético no país.

A natureza da pesquisa exploratória foi descrita como quantitativa/qualitativa. Foi possível quantificar valores em sua forma de energia térmica no estudo de caso proposto, assim como a caracterização dos materiais utilizados nas diferentes etapas de processo da pesquisa, incrementando o caráter qualitativo.

A pesquisa possui estudo de caso único como objeto de validação da metodologia Passivhaus analisada. O município do Rio de Janeiro foi escolhido para o local do estudo de caso devido às suas altas temperaturas e umidades durante boa parte do ano. Assim, justificou-se o uso da arquitetura passiva, auxiliada pelo res- 
friamento por absorção, para a climatização do ambiente em períodos de pico de temperatura externa.

Como descrito anteriormente, para a certificação Passivhaus de construção, a edificação deve ser analisada através do programa Passive House Planning Package. Desta forma, foi obtido o programa que possibilitou a análise do modelo arquitetônico inicial e suas modificações propostas no estudo de caso. Foram utilizados também programas para elaboração da forma arquitetônica em 3D da edificação e para coleta e aquisição de dados referentes a: radiação solar, temperatura média mensal, amplitude térmica diária, umidade relativa e ponto de orvalho, no município do Rio de Janeiro.

O estudo de caso analisado teve início pela coleta de dados da estação meteorológica localizada no Jardim Botânico, situado na zona sul do município do Rio de Janeiro (RJ), através do programa Meteonorm. A escolha do programa para coleta de dados foi realizada através da busca de mercado por uma ferramenta com a capacidade de fornecer "outputs" de dados meteorológicos adaptados para serem introduzidos ao programa PHPP. A extensa base de dados existente no Meteonorm e sua adaptabilidade a diferentes programas de modelagem climatológica, além de sua confiabilidade perante o Passivhaus Institute (PHI), foram motivos que levaram a sua escolha.

Devido ao caráter exploratório do estudo, no intuito de demonstrar a ferramenta de cálculo PHPP e a redução da carga térmica de uma edificação utilizando os critérios adotados pela Passivhaus, foram estabelecidas determinadas características da edificação analisada no estudo de caso. Essas características iniciais (número de habitantes, área de piso total, transmissividade térmica dos elementos construtivos, etc.), que serão descritas posteriormente, serviram de base comparativa para a mudança arquitetônica proposta pela Passivhaus. Utilizou-se um programa de modelagem 3D para a visualização da edificação inicial.

Após serem estabelecidos os parâmetros iniciais da edificação e serem coleta dos os dados meteorológicos do local, realizou-se a modelagem tridimensional da mesma, calculando o balanço termodinâmico através do programa PHPP. Este gerou resultados quanto a demanda mensal de energia a ser retirada para as condições de conforto internas da edificação atingirem a certificação Passivhaus.

Os critérios impostos de limite de temperatura ambiente $20-25{ }^{\circ} \mathrm{C}$, umidade relativa do ar inferior a $75 \%$ e demanda anual de resfriamento da edificação em 
$15 \mathrm{kwh} / \mathrm{m}^{2}$, foram analisados e comparados aos valores resultantes da edificação inicial.

Com o resultado da carga térmica obtida através do programa, diferentes formas arquitetônicas (mudanças nas áreas de fachadas e pisos) e elementos construtivos (brises, materiais isolantes térmicos, etc.) foram projetados na modelagem 3D, utilizando os critérios da arquitetura Passivhaus, no intuito de reduzir a demanda energética para a climatização da edificação.

Desta forma, o programa PHPP foi novamente utilizado como forma de quantificar a carga térmica obtida nas mudanças arquitetônicas da edificação modelo inicial. Criou-se um fluxograma da metodologia utilizada para o estudo de caso, representado pela Figura 20.

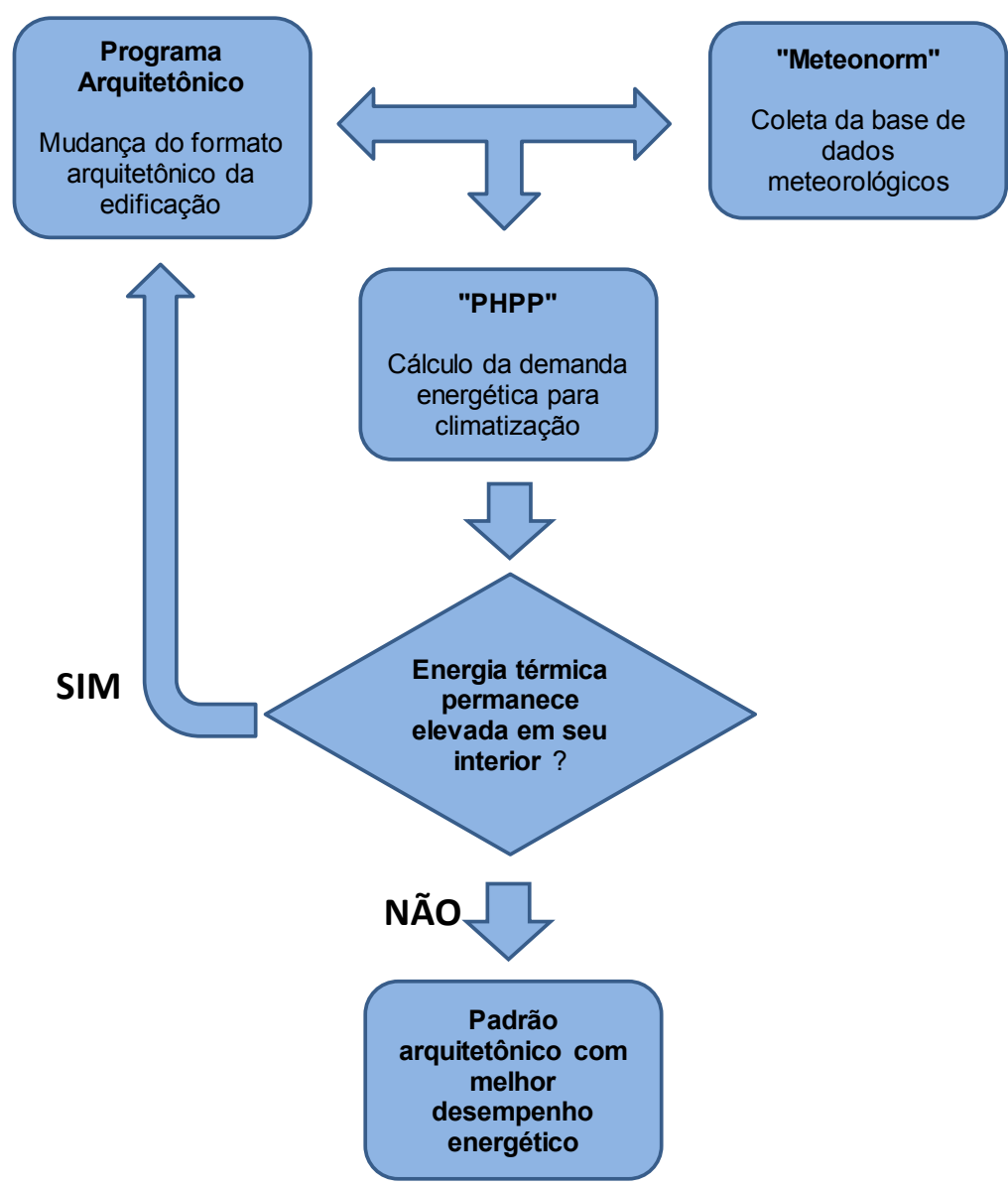

Figura 20 - Fluxograma da metodologia utilizada

Realizado o cálculo do novo balanço térmico da edificação e encontrando-o elevado (acima dos limites estabelecidos para certificação), voltou-se à modelagem 3D, reformulando o modelo arquitetônico da edificação passiva. A contínua modificação arquitetônica teve o intuito de reduzir a carga térmica no interior da 
residência a ser calculada através do PHPP. Este ciclo, como visto na Figura 20, foi repetido até o ponto onde as mudanças arquitetônicas e os elementos construtivos da edificação se mostraram ineficientes na redução da energia térmica acumulada em seu interior.

Com os resultados obtidos através do PHPP, o sistema de resfriamento por absorção foi devidamente dimensionado. Calculou-se o número de coletores solares em série e em paralelo para que atendessem ao fluxo de água e energia térmica nominais do refrigerador de absorção. O projeto de um reservatório termicamente isolado, assim como o tempo necessário para que o sistema de resfriamento desse partida, foram elaborados. A escolha dos painéis solares termais e do refrigerador de absorção utilizados no estudo de caso foi realizada através de pesquisas de mercado.

Cálculos do fluxo energético da radiação solar convertidos em energia térmica através dos painéis foram feitos. Após o dimensionamento completo do sistema coletor solar, constatou-se, através da comparação entre a energia térmica diária requerida para climatização da edificação e a energia térmica diária capaz de ser retirada do ambiente através da máquina de absorção, que o sistema de resfriamento introduzido na edificação foi capaz de retirar energia térmica suficiente nos dias mais quentes do ano, atendendo por completo aos critérios de certificação.

Em determinados meses do ano, a carga térmica no interior da edificação se mostrava reduzida, devido às condições de temperatura interna e umidade relativa serem próximas às idealizadas pela normativa. Assim, o excedente de energia térmica gerado pelos coletores solares foi devidamente utilizado para o aquecimento da água para uso doméstico da edificação.

\section{1}

\section{Dados de projeto estabelecidos}

Com intuito comparativo entre a análise do balanço térmico de uma edificação experimental inicial, localizada no Rio de Janeiro, através do programa PHPP, e uma edificação seguindo o modelo arquitetônico Passivhaus, alguns parâmetros foram estabelecidos: 
- Edificação localização do município do Rio de Janeiro, fazendo uso dos parâmetros meteorológicos da estação do Jardim Botânico (RJ), coletados através do programa Meteonorm;

- Posicionamento da edificação em zona urbana, possuindo um coeficiente de sombreamento no valor de 0,4 (valor determinado pelo PHPP);

- Uso de tinta clara para a pintura externa da edificação, possuindo um coeficiente de reflexão no valor de 0,4 ;

- $\quad$ Área de piso correspondente a $300 \mathrm{~m}^{2}$ por pavimento;

- $\quad$ Edificação possuindo 4 pavimentos;

- $\quad$ Pé direito correspondendo a 3 metros de altura;

- Ocupação de 5 habitantes por pavimento, totalizando 20 habitantes na edificação (valor experimental imposto para análise);

- $\quad$ Laje de piso quadrada, possuindo dimensões de 17,5 m x 17,5 m;

- Condutividade térmica das paredes e lajes da estrutura correspondendo a 1 (W/mK), com espessuras no valor de $250 \mathrm{~mm}$ (LAMBERTS, 2013);

- $\quad$ Edificação inicial não possui materiais isolantes térmicos em sua alvernaria;

- $\quad$ Devido a capacidade da ferramenta PHPP simular o fluxo de massa de ar de maneira simplificada, adotou-se um valor $30 \%$ de renovação de ar do volume da edificação, por hora, no período diurno e $15 \%$ no período noturno. Esses fluxos de ar correspondem a valores mínimos para garantir as condições higiênicas da edificação (PHI, 2013);

- $\quad$ Áreas correspondentes às janelas, possuindo um valor superior a 1/6 da área de piso da edificação, devido à maior circulação de ar natural (LAMBERTS, 2013);

- Janelas distribuídas igualmente entre as diferentes fachadas, possuindo um comprimento e altura correspondente a 3 e $1,5 \mathrm{~m}$, respectivamente. Como estudo inicial, fez-se a instalação de 3 janelas em cada fachada por pavimento;

- Vidros e esquadrias simples, possuindo transmissividade térmica correspondente a 5,8 e $1,6 \mathrm{~W} / \mathrm{m}^{2} . \mathrm{k}$, respectivamente (valores estipulados pelo PHPP para vidros e esquadrias simples); 
- Vidros simples possuindo valores de ganho solar (Valor-G) correspondente a 0,5 (valor estipulado pelo PHPP para vidros simples);

- Inexistência de proteção adicional nas janelas;

- Inexistência de pontes térmicas;

- $\quad$ Para efeito de análise, considerou-se a amplitude térmica diária máxima do local de estudo, constante, no valor correspondente a $10{ }^{\circ} \mathrm{C}$;

- $\quad$ Paredes internas da edificação possuindo $150 \mathrm{~mm}$ de espessura;

- $\quad$ Estanqueidade da edificação de acordo com a normativa da certificação estudada;

- Consumo energético primário anual da edificação desconsiderado, devido à quantidade de variantes que afetam o seu dimensionamento.

Os parâmetros adotados descritos anteriormente somados aos dados meteorológicos coletados a seguir, serviram como base quantitativa para dar início às simulações de carga térmica da edificação, resultando em mudanças no modelo arquitetônico e de seus elementos, propostos pela Passivhaus.

\section{2}

\section{Aquisição de dados meteorológicos}

Como descrito anteriormente, o estudo de caso no Rio de Janeiro teve início pela coleta de dados climáticos mensais do município do Rio de Janeiro (estação do Jardim Botânico) referentes à radiação solar nas diferentes fachadas e na laje superior, à umidade relativa, à temperatura do ar e à temperatura do ponto de orvalho.

Utilizou-se o programa Meteonorm para produzir tais informações em um período compreendido entre 1991-2010 (período de dados armazenados pelo programa). A Tabela 7 mostra os dados climatológicos extraídos no programa Meteornorm para um ambiente localizado na cidade do Rio de Janeiro. 
Tabela 7 - Dados climáticos do município do Rio de Janeiro

\begin{tabular}{|c|c|c|c|c|c|c|c|c|}
\hline \multicolumn{4}{|c|}{$\begin{array}{c}\text { Local: } \\
\text { Rio de Janeiro }\end{array}$} & \multicolumn{2}{|c|}{$\begin{array}{l}\text { Latitude: } \\
-22.917\end{array}$} & \multicolumn{3}{|c|}{$\begin{array}{c}\text { Longitude: } \\
-43.167\end{array}$} \\
\hline \multicolumn{6}{|c|}{$\begin{array}{c}\text { Altitude: } \\
(\mathrm{m})\end{array}$} & \multicolumn{3}{|c|}{$\begin{array}{l}\text { Período de coleta de dados: } \\
\qquad 1991-2010\end{array}$} \\
\hline Mês & $\begin{array}{l}\text { Ta } \\
{ }^{\circ} \mathrm{C}\end{array}$ & $\begin{array}{l}\text { To } \\
{ }^{\circ} \mathrm{C}\end{array}$ & $\underset{\mathrm{kwh} / \mathrm{m}^{2}}{\mathbf{H}_{-} \mathbf{N}}$ & $\underset{\mathrm{kwh} / \mathrm{m}^{2}}{\mathbf{H} \mathbf{L}}$ & $\underset{\mathrm{kwh} / \mathrm{m}^{2}}{\text { H_S }}$ & $\begin{array}{c}\mathbf{H}_{-} \mathbf{O} \\
\mathrm{kwh} / \mathrm{m}^{2}\end{array}$ & $\underset{\mathrm{kwh} / \mathrm{m}^{2}}{\mathbf{H}_{-}}$ & $\mathbf{U}_{\%} \mathbf{R}$ \\
\hline Janeiro & 26,4 & 22,1 & 56 & 106 & 69 & 95 & 181 & 77 \\
\hline Fevereiro & 26,8 & 22,3 & 60 & 95 & 52 & 87 & 157 & 76 \\
\hline Março & 26,4 & 22,1 & 89 & 99 & 46 & 93 & 162 & 77 \\
\hline Abril & 25,4 & 21,2 & 93 & 70 & 39 & 71 & 122 & 78 \\
\hline Maio & 23,0 & 18,7 & 128 & 70 & 34 & 77 & 119 & 77 \\
\hline Junho & 22,2 & 18,0 & 114 & 58 & 29 & 62 & 96 & 77 \\
\hline Julho & 21,3 & 17,0 & 137 & 72 & 33 & 76 & 118 & 76 \\
\hline Agosto & 22,2 & 17,5 & 111 & 73 & 38 & 75 & 126 & 75 \\
\hline Setembro & 22 & 17,9 & 82 & 74 & 42 & 72 & 127 & 76 \\
\hline Outubro & 23,7 & 19,6 & 69 & 87 & 50 & 83 & 151 & 78 \\
\hline Novembro & 24,7 & 20,4 & 53 & 86 & 59 & 94 & 158 & 77 \\
\hline Dezembro & 25,7 & 21,6 & 54 & 97 & 71 & 94 & 174 & 78 \\
\hline
\end{tabular}

Fonte: Coletados através do Meteonorm, entre 1991-2010, (2015)

Onde Ta é a temperatura atmosférica média mensal; To é a temperatura do ponto de orvalho média mensal; H_N é a radiação Global na orientação norte média mensal; H_L é a radiação Global na orientação leste média mensal; H_S é a radiação Global na orientação sul média mensal; H_O é a radiação Global na orientação oeste média mensal; H_H é a radiação Global na horizontal média mensal; U_R é a umidade Relativa do ar média mensal.

Para uma melhor interpretação dos resultados obtidos utilizando o programa Meteonorm, elaborou-se as Figura 21 e Figura 22. 


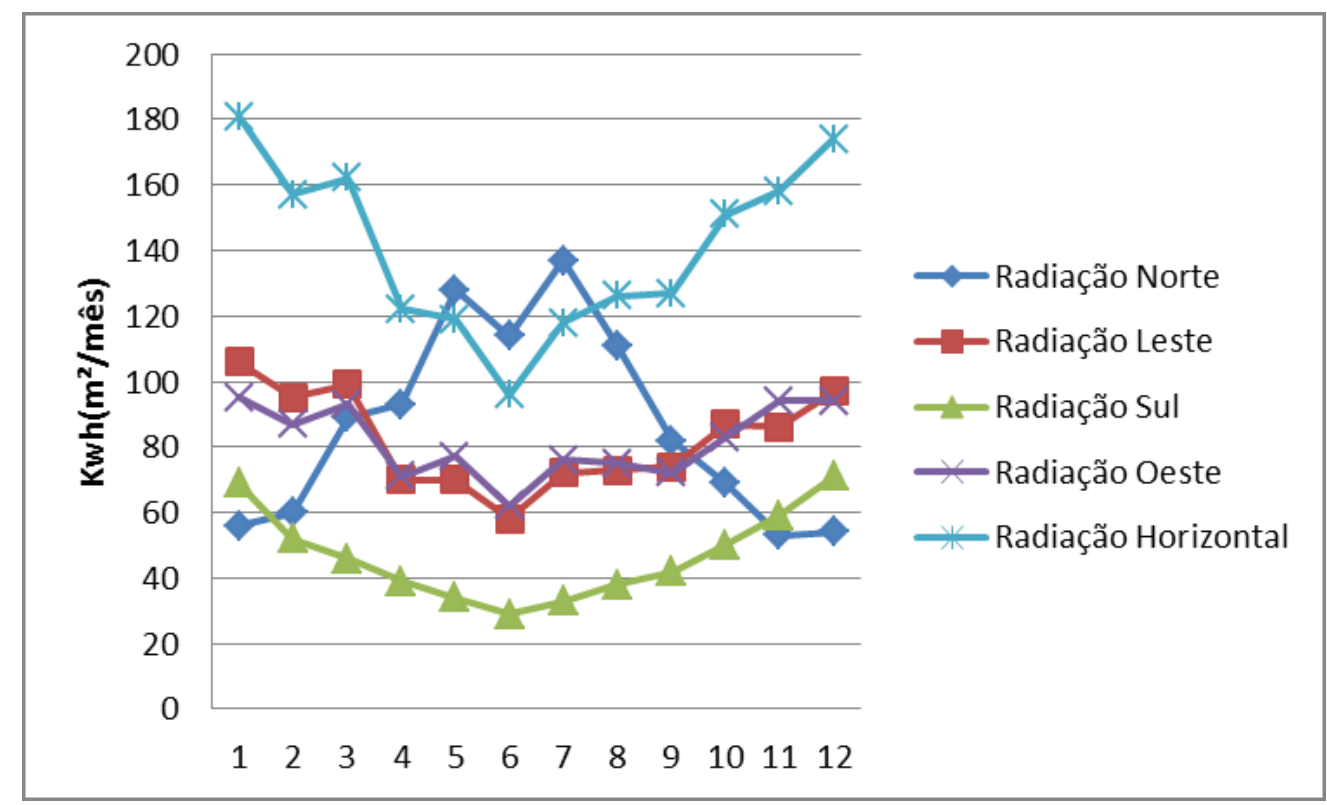

Figura 21 Balanço de radiação solar nas diferentes orientações ao longo dos meses (média mensal)

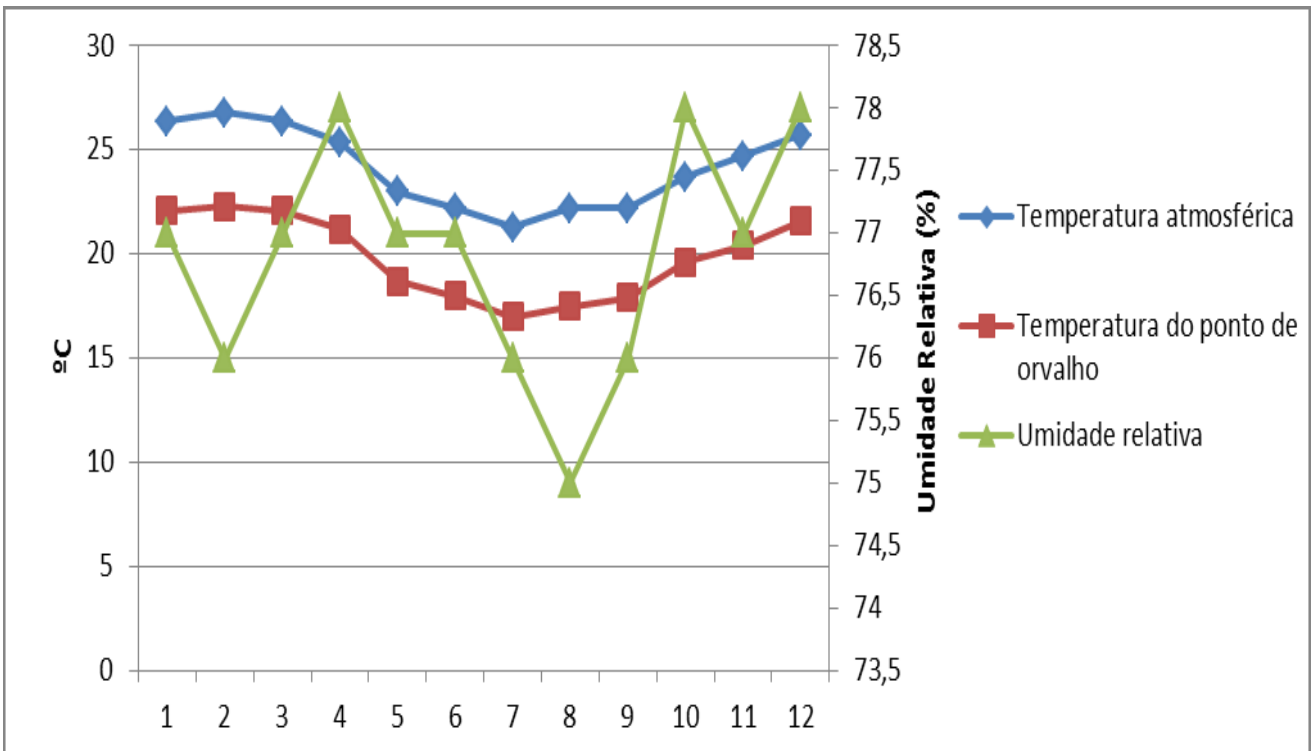

Figura 22 - Balanço de temperatura atmosférica, ponto de orvalho e umidade relativa ao longo dos meses (média mensal)

Observou-se através da Figura 21, picos de radiação solar media na orientação norte ao longo dos meses de abril, maio, junho, julho, e agosto, em comparação às demais orientações. A orientação leste, oeste e o sentido horizontal seguem recebendo quantidades constantes de radiação solar ao longo do ano. A orientação sul recebe uma baixa quantidade de radiação solar média em relação às demais.

Aferiu-se a radiação anual acumulada nas orientações leste/oeste (1.966 $\mathrm{kwh} / \mathrm{m}^{2}$.ano) e nas orientações norte/sul (1.608 kwh/m².ano). Assim, uma residência com suas maiores fachadas voltadas para o norte/sul possui uma menor inci- 
dência de radiação solar anual em comparação a uma mesma estrutura com suas maiores superfícies orientadas a leste/oeste.

A radiação solar média na fachada norte segue tendências de intensidade oposta às outras orientações, apresentando-se com maior intensidade no inverno do que no verão. Justificou-se esse acontecimento devido à posição solar ao longo do ano, descrita pelo ângulo zenital e o ângulo resultante da altura solar.

Segundo CORBELLA (p.209, 2003), o sol descreve uma trajetória plana variando seu plano todos os dias. O plano da trajetória possui uma inclinação constante, referente à latitude do lugar em análise.

Uma edificação no hemisfério sul recebe uma menor incidência de raios solares no verão em sua superfície orientada para o norte devido a maior angulação entre o plano de trajetória solar e o plano horizontal. Esse mesmo acontecimento se contrapõe no inverno, onde o ângulo de incidência de radiação solar na superfície orientada para o norte se apresenta com uma angulação quase ortogonal devido à menor altura solar de seu plano de trajetória. A Figura 23 ilustra as diferentes trajetórias solares de uma edificação localizada no hemisfério sul, no período de inverno e verão. Os ângulos de altura solar nos seus períodos de solstício foram representados.

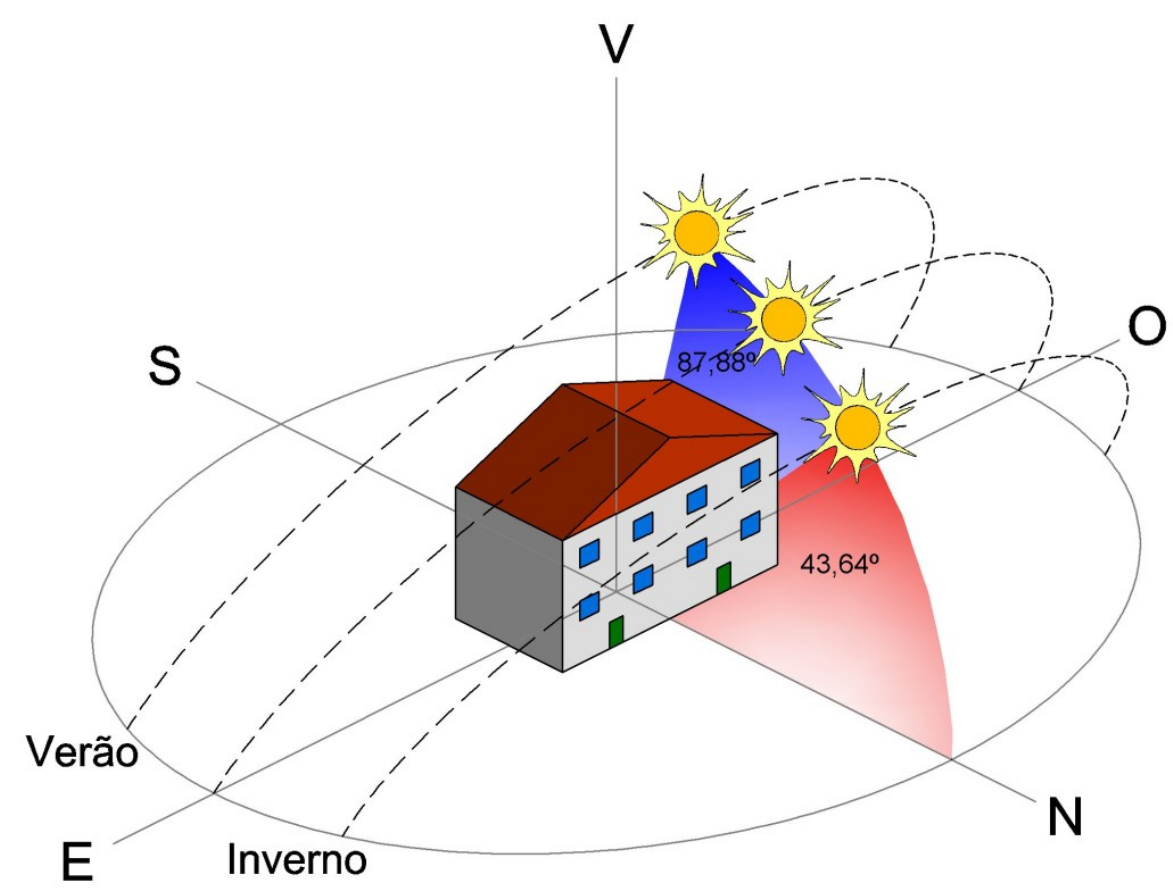

Figura 23 - Diferença no posicionamento solar da fachada norte no período de inverno e verão 
A temperatura média mensal externa e de ponto de orvalho (Figura 22) possuem valores superiores a $20^{\circ} \mathrm{C}$ e $17^{\circ} \mathrm{C}$, respectivamente, ao longo do ano. Nos meses de janeiro, fevereiro e março foram relatadas temperaturas médias superiores a $25{ }^{\circ} \mathrm{C}$, temperatura acima do limite máximo para o critério de conforto. Assim, o modelo arquitetônico final proposto teve o intuito de manter as condições de conforto interno da edificação: temperaturas no valor mínimo de $20^{\circ} \mathrm{C}$ e máximo de $25^{\circ} \mathrm{C}$; não possuir $10 \%$ dos dias do ano com temperaturas superiores à máxima; umidade relativa máxima de $75 \%$; demanda energética para o resfriamento do ambiente inferior a $15 \mathrm{kwh} / \mathrm{m}^{2}$.ano.

\section{3 \\ Modelagem arquitetônica inicial}

Utilizando os dados iniciais do projeto estabelecido no item 6.1 elaborou-se o modelo inicial da edificação em análise, fazendo uso de um programa computacional. Sua vista em perspectiva e planta estão detalhadas a seguir nas Figura $24 \mathrm{e}$ Figura 25, respectivamente:

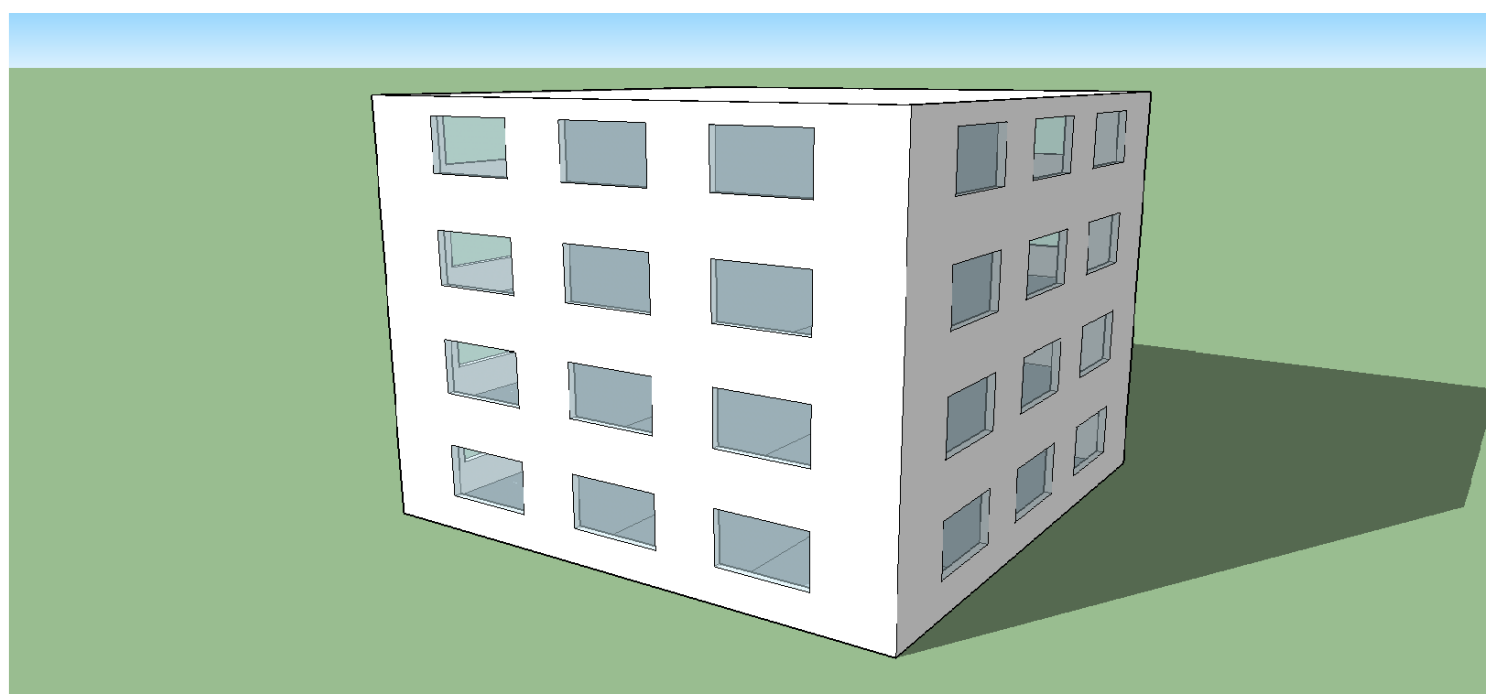

Figura 24 - Vista em perspectiva 


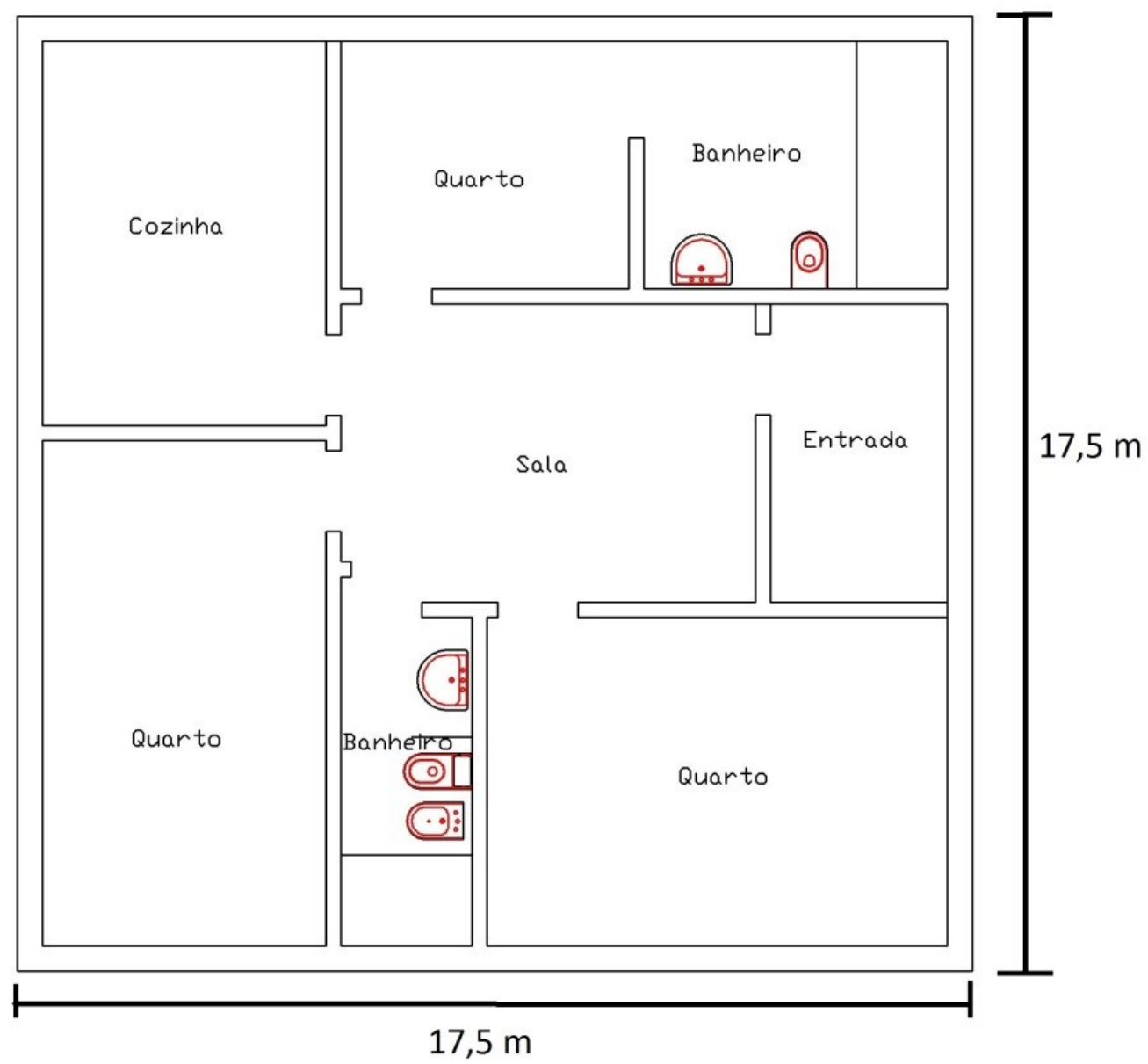

Figura 25 - Planta baixa da edificação

A planta baixa (Figura 25) foi desenvolvida no intuito de simular o interior de uma real edificação. Após a elaboração da modelagem arquitetônica, utilizaram-se os dados meteorológicos adquiridos no estudo de caso (item 6.2) para serem imputados no programa Passive House Planning Package.

A Tabela 8 é resultado dos dados de "output" do programa PHPP, fornecendo a carga térmica (calor sensível + calor latente) mensal e acumulada do ambiente interno da edificação, inicialmente elaborado.

Observou-se na Tabela 8 a carga térmica acumulada do modelo de edificação proposto, correspondendo a $97,6 \mathrm{kwh} / \mathrm{m}^{2}$.ano. Esse valor é referente a quantidade de energia térmica concentrada no interior da edificação, no período de 1 ano.

Possuindo como comparativo o critério de conforto Passivhaus, que limita a carga térmica anual da edificação em $15 \mathrm{kwh} / \mathrm{m}^{2}$.ano, a edificação em análise possui um valor correspondente a 6,5 vezes o valor de conforto, apresentando um baixo desempenho energético segundo a normativa. 
Tabela 8 - Resultados de Output do programa Passive House Planning Pachage

\begin{tabular}{c|c|c|c|c}
\hline Meses & $\begin{array}{c}\text { Demanda energé- } \\
\text { tica de calor la- } \\
\text { tente } \\
\left(\mathrm{Kwh} / \mathrm{m}^{2}\right)\end{array}$ & $\begin{array}{c}\text { Demanda energé- } \\
\text { tica de calor sen- } \\
\text { sível } \\
\left(\mathrm{Kwh} / \mathrm{m}^{2}\right)\end{array}$ & $\begin{array}{c}\text { Fração sensível } \\
(\%)\end{array}$ & $\begin{array}{c}\text { Demanda } \\
\text { Energética } \\
\text { Total } \\
\left(\mathrm{Kwh} / \mathrm{m}^{2}\right)\end{array}$ \\
\hline Janeiro & 3,2 & 11,9 & 79 & 15,3 \\
\hline Fevereiro & 3,4 & 11,9 & 78 & 15,5 \\
\hline Março & 3,2 & 11,5 & 78 & 14,6 \\
\hline Abril & 2,8 & 8,1 & 74 & 10,5 \\
\hline Maio & 1,6 & 3,5 & 69 & 2,4 \\
\hline Junho & 1,3 & 0,6 & 29 & 1,6 \\
\hline Julho & 0,9 & 0,5 & 36 & 1,1 \\
\hline Agosto & 1,0 & 1,1 & 32 & 1,4 \\
\hline Setembro & 1,3 & 0,7 & 71 & 5,8 \\
\hline Outubro & 2,0 & 4,8 & 74 & 8,8 \\
\hline Novembro & 2,4 & 7,0 & 77 & 12,7 \\
\hline Dezembro & 2,9 & 10,0 & 73 & $\mathbf{9 7 , 6}$ \\
\hline Anual & 26,1 & $71,5,7$ & $\mathbf{6 3} \%$ \\
\hline \multicolumn{2}{r|}{ Frequência de Superaquecimento } & $\mathbf{1 0 0} \%$ \\
\hline
\end{tabular}

Fonte: PHPP (Modificada), 2015

Ainda na Tabela 8, os valores da frequência de superaquecimento e umidade relativa anual, se encontram acima dos parâmetros de conforto térmico determinados para sua certificação (valor limite de $10 \%$ de frequência anual).

Como descrito inicialmente no estudo de caso, o cálculo da carga térmica do modelo de edificação inicial foi utilizado como base comparativa para as simulações que irão se suceder. Diferentes elementos arquitetônicos preconizados pela Passivhaus, assim como mudanças na geometria da edificação inicial foram simuladas no intuito de reduzir a carga térmica acumulada no interior da edificação.

Os subcapítulos a seguir, resultam nas mudanças realizadas no modelo inicial que obtiveram nas simulações, os melhores desempenhos energéticos. Resultando assim, na redução da carga térmica acumulada no interior da edificação, referente a $97,6 \mathrm{kwh} / \mathrm{m}^{2}$.

\section{4}

\section{Arquitetura proposta}

Como relatado anteriormente, a arquitetura final proposta para análise de uma edificação energeticamente eficiente no Rio de Janeiro foi fruto de diferentes simulações arquitetônicas, através da utilização do programa PHPP, no intuito de 
minimizar os ganhos de energia térmica no interior da residência, almejando atingir os padrões de conforto térmico estabelecidos para a certificação do empreendimento. As vistas em perspectiva (Figura 26- Fachadas norte/oeste do modelo físico da edificação PassivhausFigura 26 e Figura 27) e a planta baixa (Figura 28) do modelo da edificação que obteve o melhor desempenho energético se encontram a seguir A estratégia do modelo físico final foi derivada da interpretação dos dados meteorológicos da Tabela 7, assim como dos conceitos da arquitetura passiva.

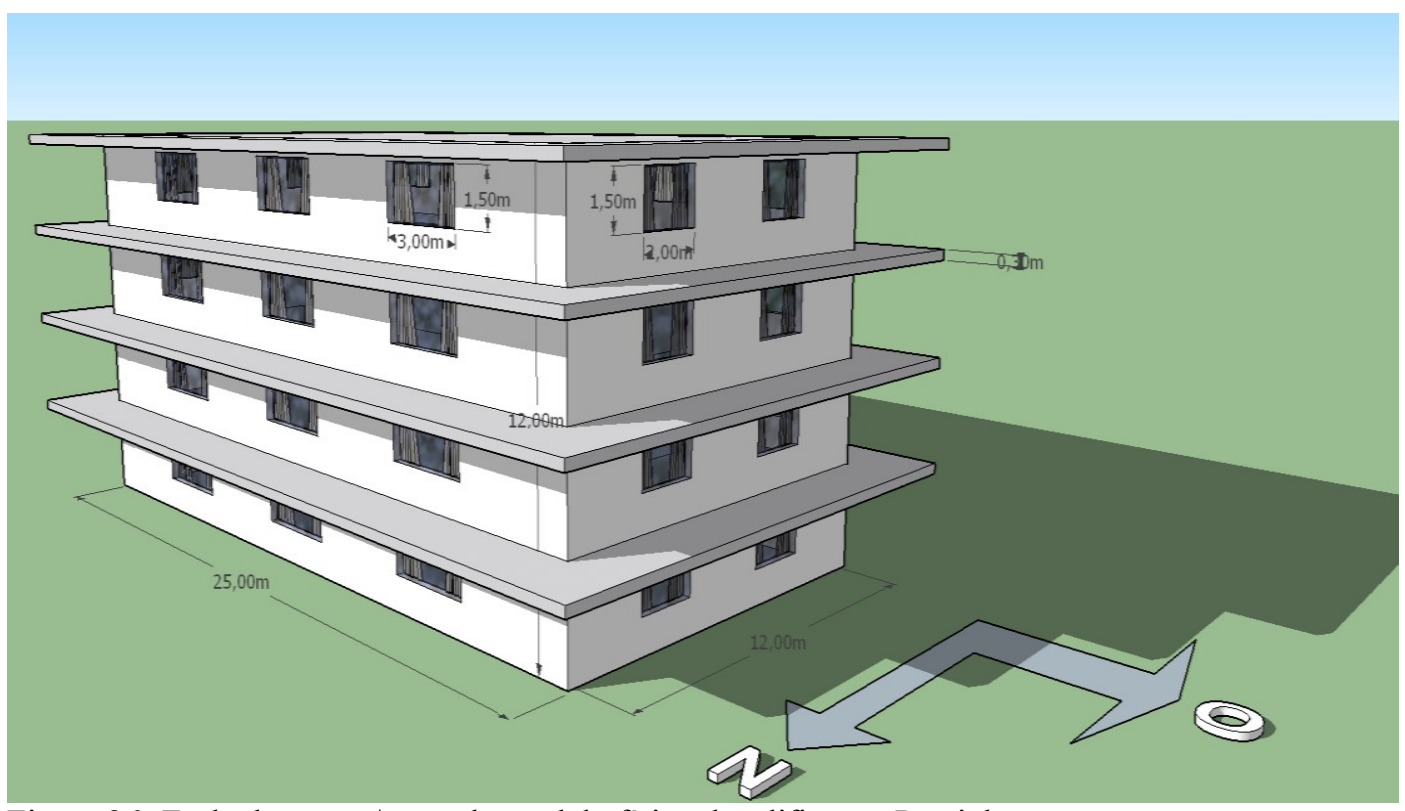

Figura 26- Fachadas norte/oeste do modelo físico da edificação Passivhaus

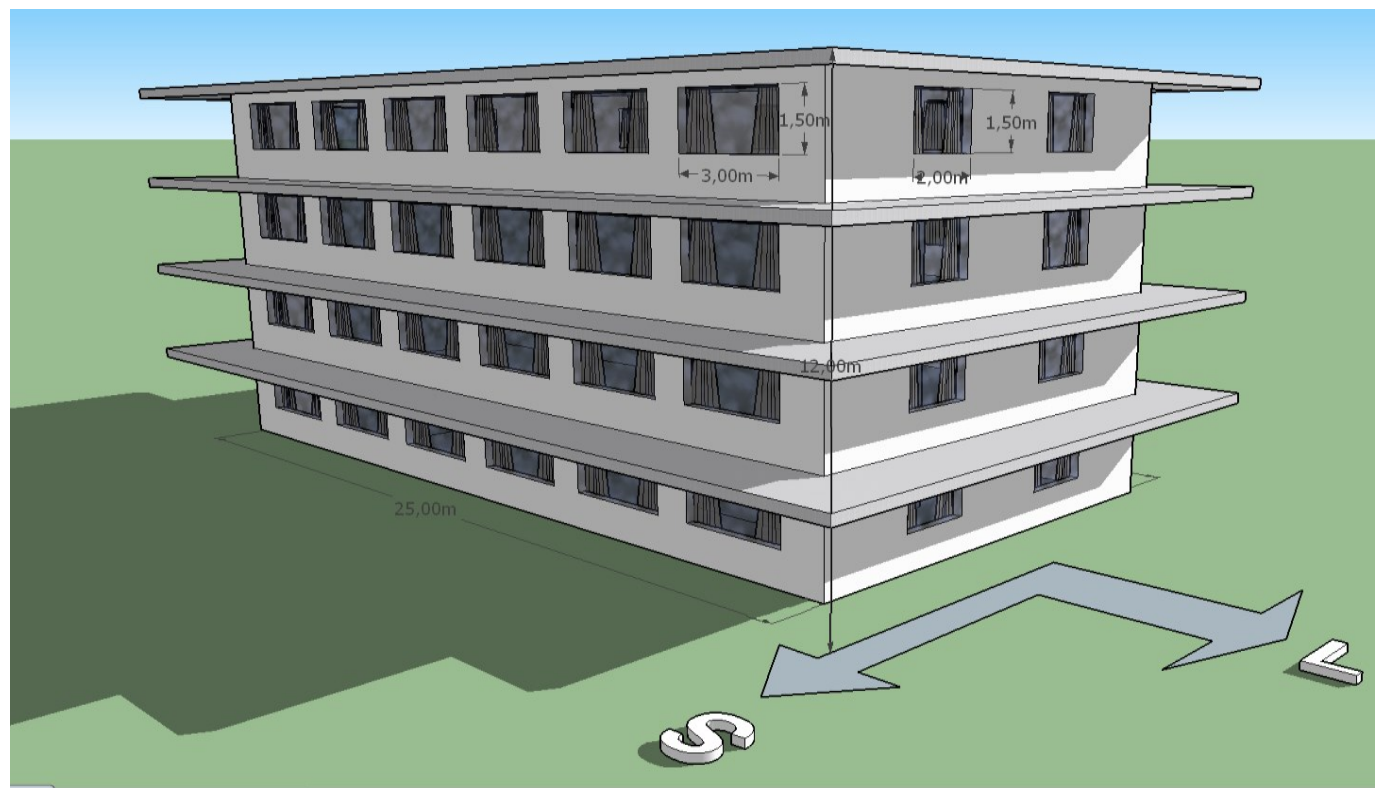

Figura 27- Fachada sul/leste do modelo físico da edificação Passivhaus 


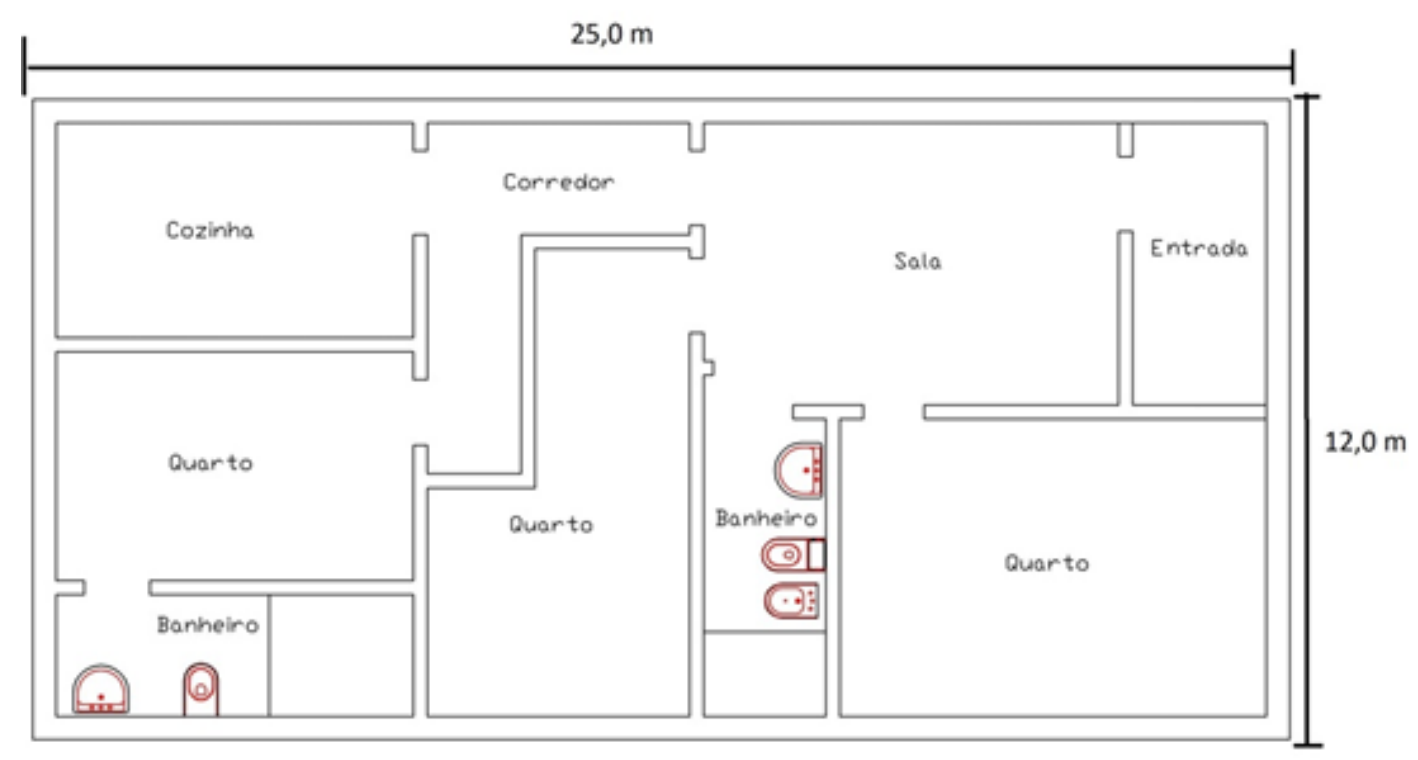

Figura 28 - Planta baixa (modelo de edificação com o melhor desempenho energético)

Como uma breve introdução aos subcapítulos que se seguem, referentes às mudanças arquitetônicas que obtiveram impacto significativo na carga térmica do modelo inicial, a geometria final retangular da edificação, com suas maiores fachadas voltadas para a orientação norte e sul, foi adotada no intuito de reduzir a radiação solar nas fachadas leste e oeste. Uma diminuição do impacto da radiação solar na fachada norte foi obtida utilizando materiais de construção com maior resistência térmica.

Paredes e janelas com valores de transmissividade térmica inferiores a 0,15 e $0,8 \mathrm{~W} / \mathrm{m}^{2} . \mathrm{K}$, respectivamente, foram analisadas seguindo o modelo de construção Passivhaus para atingir baixas demandas energéticas.

A mudança no posicionamento das janelas teve como objetivo reduzir a incidência solar na edificação. Desta forma, uma maior quantidade de janelas foi adotada na fachada sul, sendo essa quantidade reduzida nas fachadas norte, leste e oeste. A área total referente às janelas manteve-se constante ao longo das simulações realizadas.

Foram introduzidos brises horizontais fixos de 2 metros de comprimento, dando continuidade às lajes dos pavimentos e à laje de cobertura. Persianas reguláveis também foram introduzidas. Ambos os elementos possuem a função de reduzir a entrada de radiação solar na edificação, minimizando o aumento da temperatura interna. 
Nas simulações realizadas, a utilização de um sistema híbrido de ventilação, onde a entrada de ar na edificação é feita naturalmente através da abertura de janelas durante o período diurno e noturno e sua exaustão, feita mecanicamente nos ambientes mais úmidos e com possíveis odores (cozinha e banheiros), obtiveram os melhores desempenhos energéticos quanto aos sistemas de fluxo de ar simulados.

Desta forma, serão descritos a seguir os dados de Input que apresentaram os melhores resultados de eficiência energética nas simulações do programa, sendo gerado, como resultado (Output), novos valores para a demanda energética para o resfriamento da edificação, assim como valores para a frequência de superaquecimento da mesma.

\section{5 \\ Dados de input utilizados}

\section{Transmissividade térmica dos materiais}

Considerou-se uma gama de materiais de baixa condutividade térmica que poderiam ser introduzidos no estudo de caso inicial. No intuito de dificultar ao máximo a entrada da radiação solar no interior da edificação, optou-se pela adição à alvenaria tradicional de uma camada isolante de espuma de poliestireno, material que apresenta a menor condutividade térmica do mercado, referente a 0,03 W/m.K (NBR 15220, 2005).

Os valores de transmissividade térmica das paredes, laje inferior e laje superior foram calculados através da espessura da alvenaria com o isolante térmico considerado. Diferentes espessuras do isolante foram simuladas no programa com o intuito de reduzir a entrada de radiação solar na edificação.

Um fato observado foi a alta eficiência da espuma de poliestireno como isolante térmico das estruturas, porém a mesma alcança sua saturação com espessuras de $40 \mathrm{~mm}$ na parede e $80 \mathrm{~mm}$ na cobertura. Constatou-se que espessuras superiores às encontradas para o isolante térmico não determinam uma menor entrada de radiação solar na edificação, não justificando, assim, o seu uso.

Valores de transmissividade térmica de materiais opacos inferiores aos utilizados, preconizados como premissas para uma alta eficiência energética $(<0,15$ 
$\mathrm{W} / \mathrm{m}^{2} . \mathrm{K}$ ), foram também testados, porém apresentaram resultados inferiores aos escolhidos devido ao aumento da frequência de superaquecimento da edificação.

A Tabela 9 descreve os valores de transmissividade térmica considerados nas diferentes estruturas que compõem a edificação. Obteve-se um melhor desempenho energético através da redução da demanda de climatização do ambiente, utilizando camadas de $40 \mathrm{~mm}$ de espuma de poliestireno nas paredes e lajes de piso e $80 \mathrm{~mm}$ na laje superior.

A introdução do isolante térmico no modelo de edificação inicial resultou em uma redução de $11,3 \mathrm{kwh} / \mathrm{m}^{2}$. ano de sua carga térmica acumulada. 
Tabela 9 - Input de transmissividade térmica no programa

\begin{tabular}{|c|c|c|c|}
\hline \multirow{2}{*}{ Posicionamento } & Isolante na Parede & $\begin{array}{l}\text { Isolante na Laje } \\
\text { Inferior }\end{array}$ & $\begin{array}{c}\text { Isolante na Laje } \\
\text { Superior }\end{array}$ \\
\hline & Parede & Piso & Telhado \\
\hline Adjacente ao: & Ar externo & Solo & Ar Externo \\
\hline $\begin{array}{c}\text { R Interior (própria } \\
\text { estrutura) } \\
\left(\mathrm{m}^{2} . \mathrm{K} / \mathrm{W}\right) \\
\end{array}$ & 0,13 & 0,1 & 0,17 \\
\hline $\begin{array}{c}\text { R Exterior (própria } \\
\text { estrutura) } \\
\left(\mathrm{m}^{2} . \mathrm{K} / \mathrm{W}\right)\end{array}$ & 0,04 & 0 & 0,04 \\
\hline $\begin{array}{c}\boldsymbol{\Lambda 1} \text { (espuma de polies- } \\
\text { tireno) } \\
(\mathrm{W} / \mathrm{m} . \mathrm{K})\end{array}$ & 0,03 & 0,03 & 0,03 \\
\hline $\begin{array}{c}\text { Espessura } \\
(\mathrm{mm})\end{array}$ & 40 & 40 & 80 \\
\hline $\begin{array}{c}\boldsymbol{\Lambda 2} \text { (alvenaria conven- } \\
\text { cional) } \\
(\mathrm{W} / \mathrm{m} . \mathrm{K})\end{array}$ & 1 & 1 & 1 \\
\hline $\begin{array}{l}\text { Espessura } \\
\quad(\mathrm{mm})\end{array}$ & 250 & 250 & 250 \\
\hline $\begin{array}{l}\text { Valor-U } \\
\text { Final } \\
\left(\mathrm{W} / \mathrm{m}^{2} . \mathrm{K}\right)\end{array}$ & 0,572 & 0,594 & 0,364 \\
\hline
\end{tabular}

Onde R Interior é a resistividade térmica interna intrínseca do posicionamento da estrutura; R Exterior é a resistividade térmica exterior intrínseca do posicionamento da estrutura; $\kappa 1$ e $\kappa 2$ são a condutividade térmica da espuma de poliestireno e da alvenaria convencional utilizada; Valor-U é a transmissividade térmica das vedações.

\section{Área da edificação}

Mantendo constante a área de piso total do modelo arquitetônico inicial nas simulações, diferentes formatos geométricos da edificação foram analisados, respeitando-se as características de projeto impostas.

O formato geométrico da edificação que apresentou a menor demanda de energia térmica a ser retirada de seu interior foi o retangular, com o maior lado 
voltado para a orientação norte/sul. Apesar da alta incidência de radiação solar na orientação norte em boa parte do ano, a mesma pode ser controlada através da baixa transmissividade térmica das vedações existentes.

A forma retangular da edificação, possuindo o maior lado voltado para as orientações oeste/leste, também foi devidamente analisada. Essa orientação se apresentou com desempenho inferior à mesma geometria retangular com suas maiores faces voltadas para orientação norte/sul, pois constatou-se uma maior quantidade de calor sensível a ser retirada de seu interior.

Esse acontecimento foi justificado devido ao fato das fachadas oeste/leste receberem uma quantidade constante e relativamente alta de radiação solar durante todo o ano. Em contrapartida, a fachada norte possui radiações mais altas porém flutuantes ao longo do ano, além de baixas radiações incidentes na fachada sul. Assim, a geometria retangular com seu maior lado orientado para o norte/sul, se apresentou com um melhor desempenho energético do que as demais.

A Tabela 10 descreve os valores considerados referentes às áreas de cada superfície da edificação, em suas diferentes orientações, com seus respectivos valores de transmissividade térmica. Os valores "a" e " $h$ " correspondem ao comprimento e altura das dimensões superficiais externas da residência, respectivamente. Elas são descritas na Tabela 10 e derivam do formato arquitetônico adotado que obteve o melhor desempenho energético nas simulações.

Como descrito anteriormente, a forma retangular da edificação foi adotada a fim de minimizar o impacto da radiação solar segundo sua orientação leste e oeste. O valor da área total a ser tratada refere-se ao somatório das áreas de cada pavimento. Os cálculos termodinâmicos utilizados no programa irão utilizar esse valor como área total a ser climatizada.

A nova geometria arquitetônica adotada possibilitou a redução da carga térmica acumulada anualmente, em nosso modelo inicial, em $9,1 \mathrm{kwh} / \mathrm{m}^{2}$.

Manteve-se o fator de redução por sombreamento, no valor referente a 0,4 , adotado inicialmente, por se tratar de uma edificação no espaço urbano do Rio de Janeiro. Superfícies com áreas absolutamente não sombreadas se caracterizam por valores referentes ao fator de redução por sombreamento igual a 1 . 
Tabela 10 - Input das áreas da edificação

\begin{tabular}{|c|c|c|c|c|c|c|}
\hline \multicolumn{5}{|c|}{$\begin{array}{c}\begin{array}{c}\text { Área por Pavimento } \\
300 \mathrm{~m}^{2}\end{array} \\
\text { Número de Pavimentos } \\
4\end{array}$} & \multicolumn{2}{|c|}{$\begin{array}{c}\text { Área Tratada } \\
\text { Total } \\
1200 \mathrm{~m}^{2}\end{array}$} \\
\hline Orientação & $\begin{array}{c}\mathrm{a} \\
(\mathrm{m})\end{array}$ & $\begin{array}{l}\mathrm{h} \\
(\mathrm{m})\end{array}$ & $\begin{array}{l}\text { Área } \\
\text { total } \\
\left(\mathrm{m}^{2}\right)\end{array}$ & $\begin{array}{l}\text { Valor U } \\
\left(\mathrm{W} / \mathrm{m}^{2} . \mathrm{K}\right)\end{array}$ & $\begin{array}{l}\text { Fator de Redução } \\
\text { por Sombreamento }\end{array}$ & Coef. De Absorção \\
\hline $\begin{array}{l}\text { Parede Exte- } \\
\text { rior Sul }\end{array}$ & 25,0 & 12,0 & 300,0 & 0,572 & 0,4 & 0,4 \\
\hline $\begin{array}{l}\text { Parede Exte- } \\
\text { rior Norte }\end{array}$ & 25,0 & 12,0 & 300,0 & 0,572 & 0,4 & 0,4 \\
\hline $\begin{array}{l}\text { Parede Exte- } \\
\text { rior Oeste }\end{array}$ & 12,0 & 12,0 & 144,0 & 0,572 & 0,4 & 0,4 \\
\hline $\begin{array}{l}\text { Parede Exte- } \\
\text { rior Leste }\end{array}$ & 12,0 & 12,0 & 144,0 & 0,572 & 0,4 & 0,4 \\
\hline Laje Superior & 25,0 & 12,0 & 300,0 & 0,364 & 0,4 & 0,4 \\
\hline $\begin{array}{c}\text { Laje } \\
\text { Inferior }\end{array}$ & 25,0 & 12,0 & 300,0 & 0,594 & - & - \\
\hline
\end{tabular}

O coeficiente de absorção de uma superfície varia de 0 , para superfícies refletoras (espelho), até 1, para superfícies negras. $O$ valor de 0,4 foi mantido como coeficiente de absorção da edificação proposta devido à manutenção quanto ao uso de tinta branca em sua superfície, tendo seu coeficiente de absorção tabelado pelo programa com um valor de 0,4 .

Não há existência de fatores de redução da radiação por sombreamento ou coeficiente de absorção na laje inferior. Esse fato decorre do contato direto da superfície com o solo, não cabendo a utilização de fatores de redução.

\section{Vedações térmicas semi-transparentes}

No modelo inicial, foram padronizadas as dimensões das janelas da edificação, resultando em um formato retangular de 3 x 1,5 m. Para efeito analítico, diferentes quantidades e dimensões de janelas foram simuladas para aferir o desempenho energético no programa quanto à redução da demanda de refrigeração interna. A área total das janelas existentes no modelo inicial da edificação foi mantida.

No intuito de maximizar a entrada de luz natural no interior da residência e minimizar a entrada de energia térmica na mesma, o melhor desempenho energético do posicionamento das janelas foi alcançado por uma maior quantidade na fachada sul e uma menor quantidade na fachada norte, oeste e leste. 
A fachada sul foi preferida para uma maior quantidade de janelas devido à sua baixa radiação solar incidente em relação às demais. Apesar da alta incidência de radiação solar na fachada norte, justifica-se a adoção de uma menor quantidade de janelas a fim de se criar um fluxo natural de ventilação norte/sul, além de permitir a entrada de luz natural na edificação.

Com um maior número de janelas nas orientações leste/oeste obteve-se um menor desempenho energético na edificação, elevando a demanda de energia para climatização do ambiente interno. No intuito de reduzir a carga térmica total, uma menor quantidade de janelas com menores dimensões $(2 \times 1,5 \mathrm{~m})$ foram inseridas nessas orientações, permitindo assim a entrada de luz solar nas mesmas.

Após a definição do novo posicionamento das janelas, a utilização de diferentes tipos de vidros e esquadrias tiveram seus valores de transmissividade térmica e coeficiente de ganho de calor solar (Valor-G) correspondentes simulados.

Os vidros e esquadrias que possuíam valores de transmissividade térmica correspondentes a $0,8 \mathrm{~W} / \mathrm{m}^{2} . \mathrm{K}$ foram os que obtiveram melhores desempenhos energéticos.

Valores de transmissividade térmica de vidros e esquadrias superiores aos iniciais foram simulados, apresentando baixo desempenho energético na edificação. Valores inferiores a $0,8 \mathrm{~W} / \mathrm{m}^{2} . \mathrm{K}$ de transmissividade térmica também foram analisados, porém não se obtiveram valores satisfatórios de redução da demanda de energia para refrigeração interna que justificassem seu uso.

O Valor-G, referente ao coeficiente de ganhos de calor solar pela janela, foi adotado propositalmente baixo, no valor de 0,3 , aumentando a capacidade das janelas em reduzir os ganhos de calor solar.

O resultado das quantidades, dimensões e propriedades térmicas das janelas, que obtiveram o melhor desempenho energético nas simulações realizadas, encontra-se naTabela 11 a seguir. Obteve-se com essas modificações uma redução de $15,3 \mathrm{kwh} / \mathrm{m}^{2}$.ano de carga térmica referente ao modelo inicial de edificação. O valor do somatório das áreas de janelas em cada superfície de fachada foi reduzido do valor da área total de cada fachada correspondente. 
Tabela 11 - Input dos dados das janelas existentes

\begin{tabular}{|c|c|c|c|c|c|}
\hline \multicolumn{2}{|c|}{ Orientação } & Norte & Sul & Leste & Oeste \\
\hline \multicolumn{2}{|c|}{$\begin{array}{l}\text { Quantidade de janelas por pa- } \\
\text { vimento }\end{array}$} & 3 & 6 & 2 & 2 \\
\hline \multicolumn{2}{|c|}{$\begin{array}{c}\text { Comprimento individual } \\
(\mathrm{m})\end{array}$} & 3,0 & 3,0 & 2,0 & 2,0 \\
\hline \multicolumn{2}{|c|}{$\begin{array}{c}\text { Altura individual } \\
(\mathrm{m})\end{array}$} & 1,5 & 1,5 & 1,5 & 1,5 \\
\hline \multicolumn{2}{|c|}{$\begin{array}{c}\text { Área Total } \\
\left(\mathrm{m}^{2}\right)\end{array}$} & 13,5 & 27 & 6 & 6 \\
\hline \multicolumn{2}{|c|}{$\begin{array}{c}\text { Quantidade total de janelas por } \\
\text { orientação }\end{array}$} & 12 & 24 & 8 & 8 \\
\hline \multicolumn{2}{|c|}{ Tipo de Vidro } & $\begin{array}{l}\text { Vidro } \\
\text { Duplo }\end{array}$ & $\begin{array}{l}\text { Vidro } \\
\text { Duplo }\end{array}$ & $\begin{array}{l}\text { Vidro } \\
\text { Duplo }\end{array}$ & $\begin{array}{l}\text { Vidro } \\
\text { Duplo }\end{array}$ \\
\hline \multicolumn{2}{|c|}{ Valor-G } & 0,3 & 0,3 & 0,3 & 0,3 \\
\hline \multirow{2}{*}{$\begin{array}{l}\text { Valor-U } \\
\left(\mathrm{W} / \mathrm{m}^{2} . \mathrm{K}\right)\end{array}$} & Vidro & 0,8 & 0,8 & 0,8 & 0,8 \\
\hline & Esquadria & 0,8 & 0,8 & 0,8 & 0,8 \\
\hline
\end{tabular}

Os valores de transmissividade térmica adotados para os vidros e esquadrias, estão de acordo com os limites máximos de transmissividade térmica adotadas pela norma Passivhaus para elementos semi-transparentes. As características (vidro duplo e esquadria) foram escolhidas segundo a tabela de elementos certificados pelo Passivhaus Institute introduzidos no programa.

Considerou-se as portas utilizadas na edificação em análise semelhantes às características de transmissividade térmica correspondentes às paredes da residência. Assim, as portas da edificação não foram consideradas como motivo de cálculo em planilhas especiais.

\section{Sombreamento fixo e móvel da edificação}

No intuito de reduzir ao máximo a demanda de energia para a climatização do ambiente no modelo inicial, foram introduzidas diferentes formas de sombreamento da residência. $\mathrm{O}$ sombreamento com melhor desempenho térmico para a edificação foi obtido com a utilização do brise fixo horizontal, e, ainda, persianas reguláveis, sendo essas utilizadas apenas nas épocas mais quentes do ano.

Uma análise do balanço energético foi realizada no programa para descobrir a extensão ideal do brise na edificação, considerando diferentes medidas. Como resultado, um brise horizontal com extensão de 2 metros apresentou o melhor impacto energético. Assim, brises horizontais em todas as fachadas foram adotados no estudo de caso. 
Estipulou-se que a instalação de elementos de proteção solar reguláveis criariam uma melhora no balanço térmico da edificação, principalmente nos meses mais quentes do ano. Fez-se, então, simulações com persianas reguláveis para proteção da radiação solar, adotando um fator de proteção solar conservador referente a $40 \%$.

Os resultados da simulação da edificação com persianas reguláveis aliado ao a introdução de brises horizontais mostraram uma redução de $9,2 \mathrm{kwh} / \mathrm{m}^{2}$.ano da demanda de energia para climatização no verão.

\section{Sistema de ventilação adotado}

Foram realizadas simulações no programa para dois tipos de sistemas de ventilação diferentes. A ventilação híbrida, onde duas simulações com diferentes fluxos de ar $(80 \% / \mathrm{h}$ e $30 \% / \mathrm{h})$ foram simuladas (valores correspondentes a $80 \%$ e $30 \%$ do volume total da edificação trocados no período de 1 hora); a ventilação controlada de fluxo duplo, onde também foram consideradas duas hipóteses de fluxo de ar $(80 \% / \mathrm{h}$ e $30 \% / \mathrm{h})$.

Em virtude das altas umidades exteriores ao longo do ano, as simulações da edificação em análise, com um fluxo de ar referente a $80 \% / \mathrm{h}$, demonstraram um aumento da demanda energética necessária para a climatização. Assim, os sistemas de fluxos de ar de $80 \% / \mathrm{h}$ foram descartados como ideais.

Não foram encontradas diferenças relevantes na redução da demanda energética para climatização nas simulações realizadas entre o sistema híbrido de ventilação e o sistema de fluxo duplo, ambos com trocas de ar referente a $30 \% / \mathrm{h}$.

O uso dos sistemas de fluxo duplo não apresentaram vantagens competitivas, aumentando apenas o consumo elétrico da edificação para alimentação dos ventiladores. A melhor estratégia de ventilação, segundo simulações do programa PHPP, seria a ventilação híbrida (exaustão mecânica com entrada de ar natural), com fluxos de ventilação de $30 \% / \mathrm{h}$ durante o dia e $15 \% / \mathrm{h}$ durante a noite. Uma menor troca de ar com o ambiente externo no período noturno foi adotada. A carga térmica total da edificação foi reduzida em 4,2 kwh.m²/ano, utilizando o sistema de ventilação híbrido. 
O sistema de exaustão mecânica foi idealmente preferido ao sistema de exaustão passiva objetivando reduzir a umidade interna da edificação.

\section{6}

\section{Dados de output do programa}

Após o Input de todos os dados arquitetônicos que obtiveram os melhores resultados de eficiência energética nas simulações, foram coletados resultados finais do programa sobre a demanda enérgica anual, frequência de superaquecimento e frequência de umidade acima do limite máximo estabelecido. A Tabela 12 mostra os resultados da demanda energética para a climatização da edificação.

Equiparou-se os dados da Tabela 12, com os valores resultantes do modelo de edificação inicial analisado anteriormente (Tabela 8).

A demanda energética acumulada ao longo do ano foi comparada nas duas simulações realizadas. Assim, foi constatado que a edificação que utilizou os métodos estratégicos da normativa estudada obteve uma redução de 50,3\% em sua carga térmica interna, caso esta fosse construída de maneira convencional. A redução da carga térmica comprova a eficácia da metodologia estudada até o momento.

Tabela 12 - Resultados do programa sobre a demanda energética anual (Passivhaus)

\begin{tabular}{|c|c|c|c|c|}
\hline Meses & $\begin{array}{c}\text { Demanda energé- } \\
\text { tica de calor la- } \\
\text { tente } \\
\left(\mathrm{kwh} / \mathrm{m}^{2}\right)\end{array}$ & $\begin{array}{c}\text { Demanda energé- } \\
\text { tica de calor sen- } \\
\text { sível } \\
\left(\mathrm{kwh} / \mathrm{m}^{2}\right)\end{array}$ & $\begin{array}{c}\text { Fração sensível } \\
(\%)\end{array}$ & $\begin{array}{c}\text { Demanda } \\
\text { Energética } \\
\text { Total } \\
\left(\mathrm{kwh} / \mathrm{m}^{2}\right) \\
\end{array}$ \\
\hline Janeiro & 3,1 & 3,6 & 54 & 6,7 \\
\hline Fevereiro & 3,2 & 3,7 & 53 & 6,9 \\
\hline Março & 3,0 & 3,4 & 53 & 6,4 \\
\hline Abril & 2,7 & 2,8 & 51 & 5,5 \\
\hline Maio & 1,5 & 1,4 & 47 & 2,9 \\
\hline Junho & 1,6 & 0,2 & 13 & 1,8 \\
\hline Julho & 1,0 & 0,0 & - & 1,0 \\
\hline Agosto & 1,1 & 0,4 & 24 & 1,5 \\
\hline Setembro & 1,5 & 0,2 & 13 & 1,7 \\
\hline Outubro & 1,9 & 1,7 & 47 & 3,6 \\
\hline Novembro & 2,3 & 2,3 & 50 & 4,6 \\
\hline Dezembro & 2,8 & 3,1 & 52 & 5,9 \\
\hline Anual & 25,7 & 22,8 & 47 & 48,5 \\
\hline \multicolumn{3}{|c|}{ Frequência de Superaquecimento } & \multicolumn{2}{|c|}{$23 \%$} \\
\hline \multicolumn{3}{|c|}{ Frequência de umidade acima do limite } & \multicolumn{2}{|c|}{$32 \%$} \\
\hline
\end{tabular}


Apesar da introdução de critérios arquitetônicos passivos, observou-se, através dos resultados da Tabela 12, um valor superior ao limite estipulado para a demanda anual de climatização do ambiente interno da edificação. Seu valor, referente a $48,5 \mathrm{kwh} / \mathrm{m}^{2}$.ano, foi decorrente de duas parcelas de calor: o sensível e o latente.

Devido às altas condições de umidade do ambiente externo, a fração sensível da energia térmica a ser retirada do ambiente interno é relativamente baixa. Esse fato demonstra que boa parte da demanda energética necessária para o resfriamento da edificação é devido à retirada do calor latente existente em sua forma de vapor de água.

Observa-se, em países tropicais quentes e úmidos, o esforço para adequar a edificação aos critérios limites de umidade relativa do ar para a certificação. Assim, apesar da importância do cálculo da carga térmica total da edificação, os critérios para a certificação em climas com essas características devem ser contestados em estudos futuros. Esse fato decorre das diferenças climáticas desses países em relação ao local de origem da normativa analisada (pais frio e seco).

A frequência de superaquecimento referente aos meses mais quentes do ano, no valor correspondente de $23 \%$, é superior ao limite máximo estabelecido por norma $(\leq 10 \%)$.

O valor da frequência de umidade relativa anual da edificação, inferior ao limite máximo determinado pela norma $(\leq 10 \%)$, não é alcançado. A frequência de umidade relativa no interior da edificação, superior a $75 \%$, foi calculada em $32 \%$ ao ano. Apesar do sistema de exaustão introduzido na edificação, não se obtiveram valores que se adequem aos critérios de certificação. A Figura 29 foi retirada do resultado do programa PHPP.

A Tabela 13 a seguir foi elaborada através da comparação entre os dados de Output do programa (utilizando o modelo arquitetônico de melhor desempenho energético) com os valores dos critérios estabelecidos para a certificação. 
Tabela 13 - Comparações realizadas através do programa PHPP

\begin{tabular}{c|c|c|c}
\hline \multicolumn{5}{c}{ Temperatura Interna limite } \\
$20-25^{\circ} \mathrm{C}$
\end{tabular}

A não conformidade da edificação quanto a: critérios de demanda energética para climatização; frequência de superaquecimento; frequência de umidade acima do limite estabelecido; determinou a necessidade de se analisar a adequação da metodologia Passivhaus em climas quentes.

Os painéis solares térmicos, tendo o sistema de resfriamento por absorção como auxiliar, foram introduzidos ao estudo de caso, almejando a certificação da arquitetura desenvolvida. 


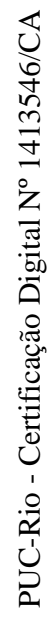

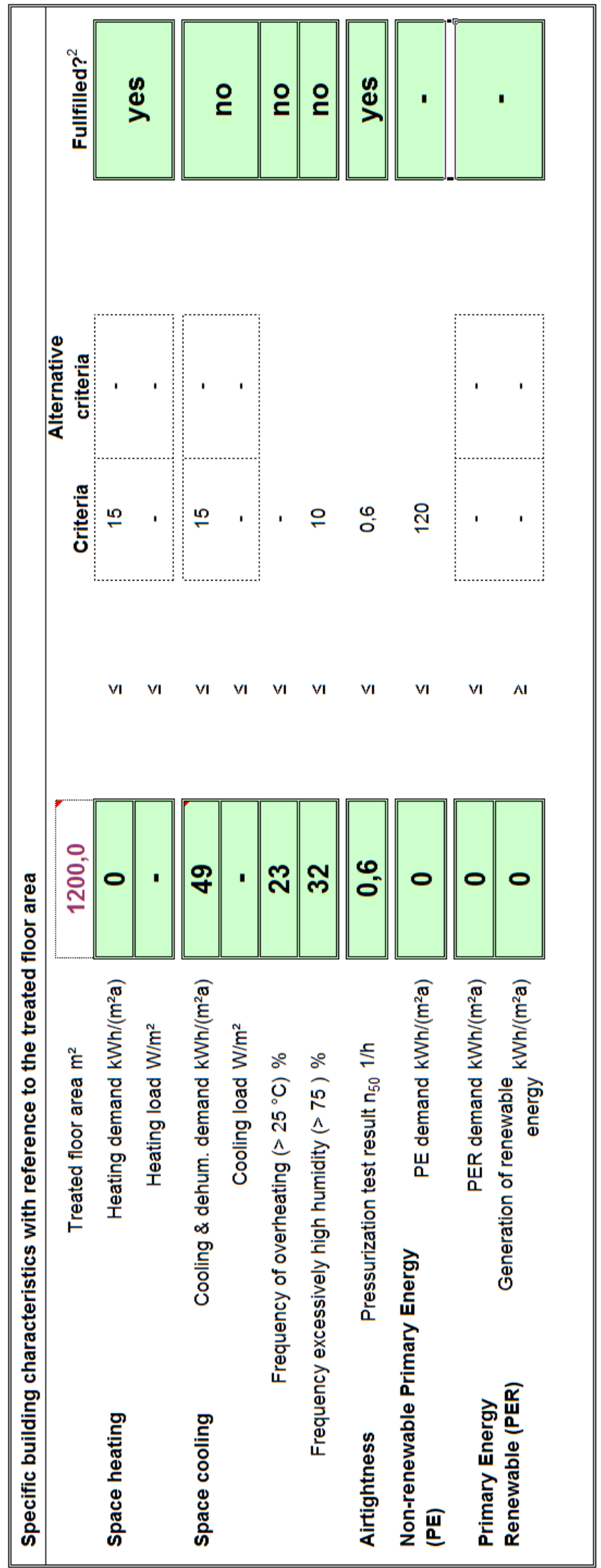

Figura 29 - Resultados do programa PHPP Fonte: Programa PHPP, 2015 


\section{7 Sistema de resfriamento por absorção}

O sistema de resfriamento por absorção utilizando Brometo de Lítio foi proposto para ser introduzido no estudo de caso, sendo alimentado por coletores solares a vácuo.

Os coletores solares a vácuo foram escolhidos devido à sua fácil instalação residencial em comparação aos coletores concentradores, além de gerar temperaturas superiores $\left(50-200^{\circ} \mathrm{C}\right)$ aos coletores solares planos. O VHP30 foi adotado como alternativa para o coletor solar a vácuo. Ele consiste em 30 tubulações de aquecimento em um único coletor solar.

No sistema, um tanque com isolamento térmico em relação ao seu exterior, foi utilizado para armazenar a água aquecida pelos painéis solares a vácuo. A água armazenada no reservatório termicamente isolado é então encaminhada ao compartimento gerador do sistema de absorção. O calor armazenado na água proveniente dos painéis solares é transferido à solução diluída de Brometo de Lítio, iniciando o processo de resfriamento por absorção. Após a perda de sua energia térmica, a água é reencaminhada ao tanque de isolamento térmico, circulando novamente através dos coletores solares.

As Tabela 14 e Tabela 15 e as Figura 30 e Figura 31 correspondem às ilustrações do painel coletor solar e do sistema de resfriamento por absorção com suas respectivas características nominais.

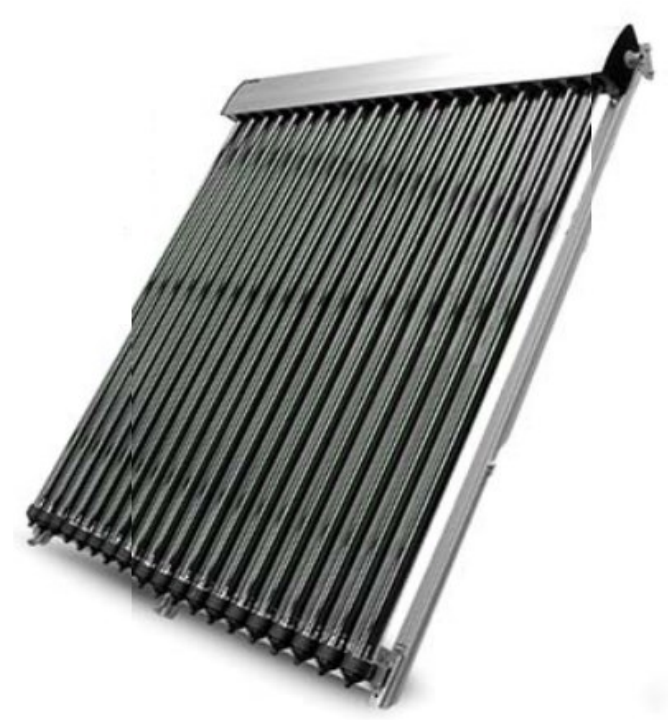

Figura 30 - ThermoPower - VHP 30

Fonte: www.sunmaxxsolar.com 
Tabela 14 - Propriedade nominal do coletor solar escolhido

\begin{tabular}{c|c}
\hline Nome do Coletor Solar: & ThermoPower -VHP30 \\
\hline Tipo de coletor: & Coletor a vácuo \\
\hline Área total do coletor $\left(\mathrm{m}^{2}\right):$ & $5,24 \mathrm{~m}^{2}$ \\
\hline Área útil do coletor $\left(\mathrm{m}^{2}\right)$ & $3,5 \mathrm{~m}^{2}$ \\
\hline Vazão unitária recomendada $(1 / \mathrm{s}):$ & $0,21 / \mathrm{s}$ \\
\hline Eficiência do Painel Solar $(\%)$ & $80 \%$ \\
\hline
\end{tabular}

Fonte: www.sunmaxxsolar.com, 2015.

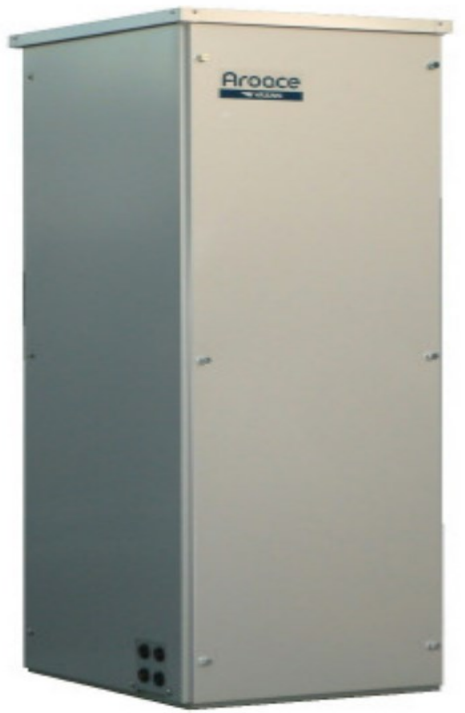

Figura 31 - Sistema Yasaki de resfriamento por absorção Fonte:www.yasakienergy.com, 2015.

Tabela 15 - Propriedade nominal do resfriador por absorção escolhido

\begin{tabular}{c|c}
\hline Nome do resfriador: & YASAKI WFC-SC5 \\
\hline Energia introduzida: & $25,1 \mathrm{kw}$ \\
\hline Capacidade de resfriamento: & $17,7 \mathrm{kw}$ \\
\hline Vazão mínima de funcionamento: & $1,2 \mathrm{l} / \mathrm{s}$ \\
\hline \multirow{2}{*}{ Temperatura necessária para funcionamento: } & Temperatura de Saída: $88^{\circ} \mathrm{C}$ \\
\cline { 2 - 2 } & Temperatura de Entrada: $83^{\circ} \mathrm{C}$ \\
\hline
\end{tabular}

Fonte: www.yazaki-airconditioning.com, 2015.

\section{Coletores Solares e armazenamento energético}

De acordo com a Tabela 15, é necessária uma vazão de 1,2 1/s para a alimentação do sistema de resfriamento por absorção analisado. A

Tabela 14 indica a vazão individual do sistema coletor solar ThermoPower VHP30, correspondendo a 0,2 1/s. Assim, serão necessários 6 coletores solares em paralelo para atingir a vazão necessária. 
Segundo a equação fundamental de calorimetria, calculou-se a quantidade de energia necessária para a elevação da temperatura do líquido circulante (água) entre os coletores solares, de uma temperatura inicial de $83{ }^{\circ} \mathrm{C}$ para $88{ }^{\circ} \mathrm{C}$, referente a uma vazão de 0,2 1/s. Obteve-se como resultado a necessidade de fornecer a água a $3.600 \mathrm{kcal} / \mathrm{hora}$, correspondendo a $4,1 \mathrm{kw}$, para sua elevação de temperatura a essa vazão.

Segundo as propriedades nominais do coletor solar analisado, sua capacidade de conversão individual de energia corresponde a $80 \%$ da energia solar. Desta forma, $80 \%$ da energia solar incidente sobre os painéis será convertida em energia térmica, havendo uma perda de $20 \%$ na conversão.

Para o cálculo do número de coletores solares em série que devem ser implantados para que ocorra uma elevação da temperatura da água em $5{ }^{\circ} \mathrm{C}$ a um fluxo de $0,21 / \mathrm{s}$, as condições climáticas no local foram estudadas.

Devido à implantação dos painéis coletores solares na laje superior, a radiação horizontal incidente na edificação foi analisada. A Tabela 16 foi elaborada através da retirada de dados da radiação horizontal mensal utilizando o programa "Meteonorm v7". Os valores de radiação mensal foram divididos pelo número de dias existentes em cada mês e convertidos em energia térmica, através da eficiência do painel solar utilizado $(80 \%)$.

Tabela 16 - Energia térmica convertida dos painéis solares por metro quadrado

\begin{tabular}{c|c|c|c|c}
\hline Mês & Dias & $\begin{array}{c}\text { Radiação Hori- } \\
\text { zontal } \\
\mathrm{kwh} / \mathrm{m}^{2} \cdot \mathrm{mês}\end{array}$ & $\begin{array}{c}\text { Radiação Hori- } \\
\text { zontal } \\
\mathrm{kwh} / \mathrm{m}^{2} \cdot \text { dia }\end{array}$ & $\begin{array}{c}\text { Conversão dos } \\
\text { painéis } \\
\mathrm{kwh} / \mathrm{m}^{2} \text {.dia }\end{array}$ \\
\hline Janeiro & 31 & 181 & 5,84 & 4,67 \\
\hline Fevereiro & 28 & 157 & 5,61 & 4,49 \\
\hline Março & 31 & 162 & 5,23 & 4,18 \\
\hline Abril & 30 & 122 & 4,07 & 3,25 \\
\hline Maio & 31 & 119 & 3,84 & 3,07 \\
\hline Junho & 30 & 96 & 3,20 & $\mathbf{2 , 5 6}$ \\
\hline Julho & 31 & 118 & 3,81 & 3,05 \\
\hline Agosto & 31 & 126 & 4,06 & 3,25 \\
\hline Setembro & 30 & 127 & 4,23 & 3,39 \\
\hline Outubro & 31 & 151 & 4,87 & 3,90 \\
\hline Novembro & 30 & 158 & 5,27 & 4,21 \\
\hline Dezembro & 31 & 174 & 5,61 & 4,49
\end{tabular}

Fonte: Meteonorm (modificado), 2015

O número de coletores solares em série foi dimensionado para o mês de Junho, onde houve uma menor radiação solar incidente sobre os painéis. A duração 
astronômica dos dias conforme os meses do ano foi analisada através da Tabela 17.

O pior cenário para o dimensionamento dos painéis solares em série, no mês de Junho, foi reafirmado por possuir um menor número de horas de radiação solar ao longo do dia, além de uma menor incidência de radiação horizontal. A potência do painel solar por metro quadrado foi calculada mensalmente, através da divisão de sua energia térmica produzida pelo número de horas astronômicas diárias mensais. Após o cálculo de sua potência por área, multiplicou-se o valor resultante pela área efetiva do coletor analisado (Tabela 14), obtendo a potência individual de cada coletor.

Observou-se, através da Tabela 17, que a potência unitária do painel solar no mês de junho corresponde ao valor de $0,84 \mathrm{kw}$. Assim, para se fornecer 4,1 kw ao fluido para elevar sua temperatura em $5{ }^{\circ} \mathrm{C}$, com uma vazão correspondente a 0,2 1/s, serão necessários 5 coletores solares ligados em série.

O número total de coletores solares foi calculado multiplicando-se o número de coletores em paralelo pelo número de coletores em série. Encontrando assim, 30 coletores.

Calculou-se a área total ocupada pelos coletores solares, multiplicando-se a sua área $\left(5,24 \mathrm{~m}^{2}\right)$ pela quantidade total de coletores no sistema.

Desta forma, serão necessários $157,2 \mathrm{~m}^{2}$ de área disponível, para que os coletores solares sejam capazes de fornecer energia térmica, a uma vazão suficiente para alimentar o sistema de resfriamento por absorção proposto.

Para armazenar a energia térmica produzida e transferida dos painéis solares, adotou-se um tanque com isolamento térmico em relação ao seu exterior.

Padronizou-se a temperatura inicial da água que circula nos painéis solares em $20^{\circ} \mathrm{C}$, temperatura essa relativa à temperatura do meio externo. Para o reservatório termicamente isolado, utilizou-se o dia mais longo do ano para o cálculo de sua capacidade de armazenamento. A duração da noite mais longa do ano (Junho) corresponde a 13,35 horas. Desta forma, o tanque deve ter a capacidade de armazenar um volume de $60 \mathrm{~m}^{3}$ de água para fornecer ao sistema de refrigeração, a uma vazão correspondente de 1,2 1/s, no período de menor duração solar. 
Tabela 17 - Potência unitária do painel solar analisado

\begin{tabular}{c|c|c|c}
\hline Mês & $\begin{array}{c}\text { Duração Astronômica } \\
\text { do dia } \\
\text { (Horas) }\end{array}$ & $\begin{array}{c}\text { Potência do Painel So- } \\
\text { lar } \\
\left(\mathrm{kw} / \mathrm{m}^{2}\right)\end{array}$ & $\begin{array}{c}\text { Potência Unitária do } \\
\text { Painel Solar } \\
(\mathrm{kw})\end{array}$ \\
\hline Janeiro & 13,25 & 0,35 & 1,23 \\
\hline Fevereiro & 12,7 & 0,35 & 1,24 \\
\hline Março & 12,15 & 0,34 & 1,2 \\
\hline Abril & 11,5 & 0,28 & 0,99 \\
\hline Maio & 10,9 & 0,28 & 0,99 \\
\hline Junho & $\mathbf{1 0 , 6 5}$ & $\mathbf{0 , 2 4}$ & $\mathbf{0 , 8 4}$ \\
\hline Julho & 10,75 & 0,28 & 0,99 \\
\hline Agosto & 11,25 & 0,29 & 1,01 \\
\hline Setembro & 11,95 & 0,28 & 0,99 \\
\hline Outubro & 12,55 & 0,31 & 1,09 \\
\hline Novembro & 13,1 & 0,32 & 1,13 \\
\hline Dezembro & 13,35 & 0,34 & 1,18 \\
\hline
\end{tabular}

A água presente no reservatório deve ser aquecida a uma temperatura de $88^{\circ} \mathrm{C}$ para que o ciclo de resfriamento por absorção ocorra. Assim, calculou-se a energia necessária para aquecer $60 \mathrm{~m}^{3}$ de água, inicialmente a $20{ }^{\circ} \mathrm{C}$, para uma temperatura de $88^{\circ} \mathrm{C}$, resultando no fornecimento de $4745 \mathrm{kw}$ para água.

Após o cálculo, foi determinada, para o mês de Junho (pior caso), a energia térmica gerada através do conjunto dos painéis coletores solares instalados, obtendo-se um valor total de $25,2 \mathrm{kwh}$. Assim, foi determinado o número de horas de radiação solar no mês de Junho para que a água do sistema de resfriamento por absorção fosse aquecida de uma temperatura inicial de $20{ }^{\circ} \mathrm{C}$ para $88{ }^{\circ} \mathrm{C}$, resultando em 188 horas para seu aquecimento.

Desta forma, foram necessários 8 dias de radiação solar para que toda água do sistema aquecesse a uma temperatura necessária para o funcionamento do equipamento de resfriamento por absorção.

A Figura 32 foi elaborada para ilustrar o estudo de caso analisado com os painéis solares implementados em sua laje superior. Os painéis solares possuem inclinação de acordo com a latitude do Rio de Janeiro $\left(22.9^{\circ}\right)$, orientados para o norte, para o melhor aproveitamento da radiação solar. 


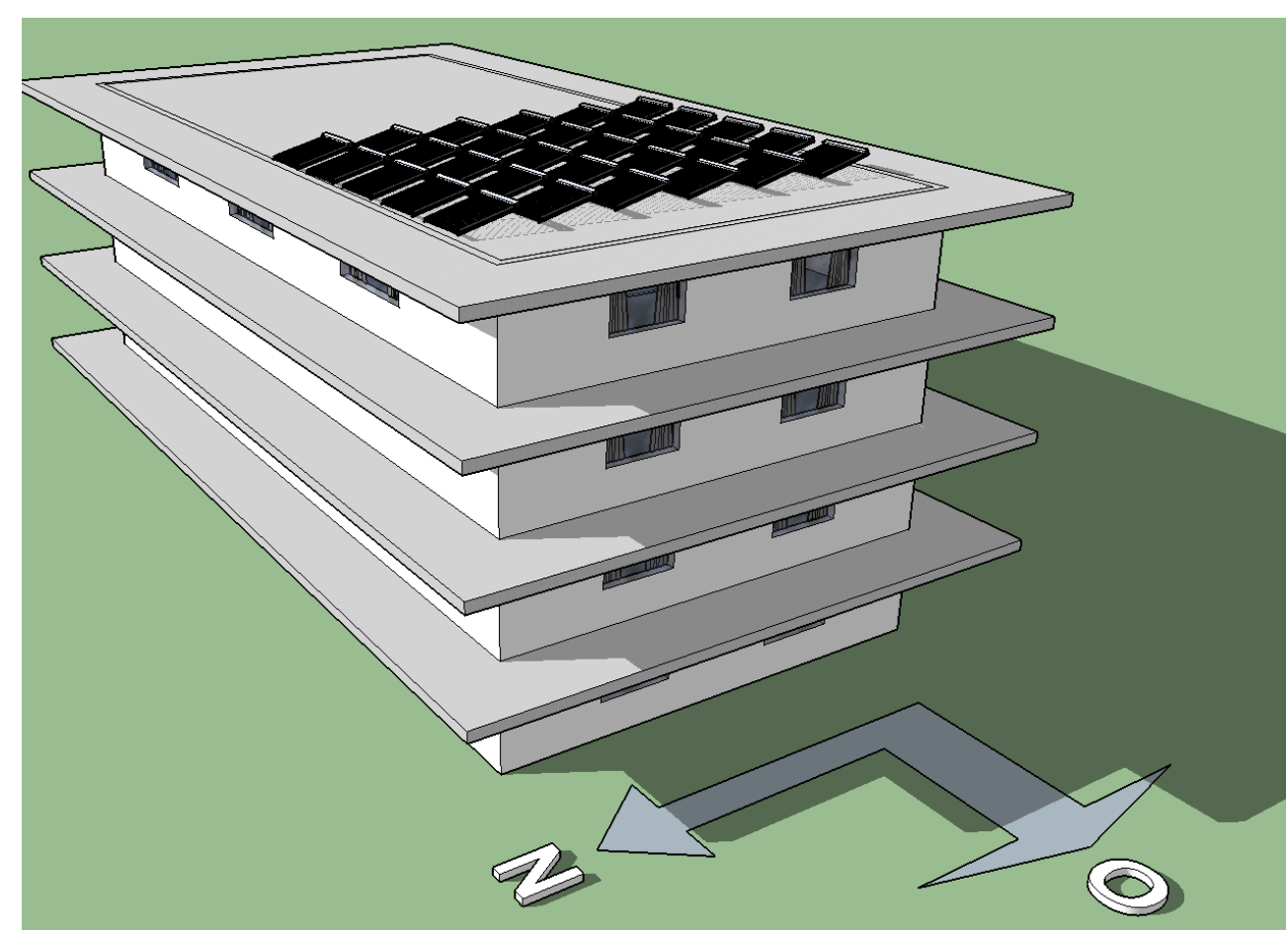

Figura 32 - Painéis solares termais e sistema de resfriamento por absorção introduzidos na residência

\section{8 \\ Resultados}

O modelo da edificação final analisada no estudo de caso possui uma demanda para refrigeração no valor de $48,5 \mathrm{kwh} / \mathrm{m}^{2}$ ao ano. Esse valor não é distribuído regularmente através dos 12 meses do ano, como visto na Tabela 12. Nos meses de Maio, Junho, Julho, Agosto e Setembro não há uma expressiva necessidade quanto ao uso do resfriamento da edificação para se adequar aos critérios de conforto preconizados pela normativa.

Possuindo $1.200 \mathrm{~m}^{2}$ de área a ser resfriada, a demanda diária energética de calor sensível e latente a ser retirado da edificação foi calculada através da Tabela 18. Compararam-se os dados resultantes, com a capacidade do Chiller de resfriamento em absorver energia térmica do ambiente.

Buscou-se utilizar o excedente de energia produzida através dos painéis solares para o aquecimento da água para uso doméstico. Assim, dimensionou-se a quantidade mensal de energia a ser fornecida, necessária, para a água para elevar sua temperatura inicial de $20^{\circ} \mathrm{C}$ a uma temperatura de conforto de $40{ }^{\circ} \mathrm{C}$. 
Fazendo uso da NBR 7198:1993, definiu-se a vazão de água quente per capita da edificação em 50 litros/hab.dia. Possuindo 20 ocupantes na edificação e utilizando a equação fundamental da calorimetria, calculou-se a energia mensal necessária para 1.000 litros de água atingirem uma temperatura de $40{ }^{\circ} \mathrm{C}$. $\mathrm{O}$ resultado é descrito na Tabela 18.

A Tabela 18 demonstra a total eficiência do sistema de resfriamento por absorção, proposto para climatizar o ambiente interno da edificação Passivhaus no Rio de Janeiro. Ainda nessa tabela, o excedente de energia produzida através dos painéis solares foi capaz de fornecer energia térmica suficiente para o abastecimento de água quente da edificação.

Tabela 18 - Resultado do atendimento dos painéis solares à demanda de resfriamento e ao aquecimento da água para uso doméstico, requeridas pela edificação

\begin{tabular}{|c|c|c|c|c|}
\hline Mês & $\begin{array}{c}\text { Energia Neces- } \\
\text { sária para o } \\
\text { Resfriamento } \\
(\mathrm{kwh} / \mathrm{dia})\end{array}$ & $\begin{array}{l}\text { Energia ne- } \\
\text { cessária para } \\
\text { aquecer a } \\
\text { água de uso } \\
\text { doméstico } \\
(\mathrm{kwh} / \mathrm{dia})\end{array}$ & $\begin{array}{l}\text { Energia retirada } \\
\text { através do Chiller } \\
\text { de Absorção } \\
(\mathrm{kwh} / \mathrm{dia})\end{array}$ & $\begin{array}{l}\text { Energia fornecida } \\
\text { atende à demanda } \\
\text { requerida de refrige- } \\
\text { ração e consumo de } \\
\text { água quente? }\end{array}$ \\
\hline Janeiro & 259,61 & 23,26 & 345,86 & Sim \\
\hline Fevereiro & 295,71 & 23,26 & 332,14 & Sim \\
\hline Março & 247,74 & 23,26 & 309,55 & Sim \\
\hline Abril & 220,0 & 23,26 & 240,89 & Sim \\
\hline Maio & 112,26 & 23,26 & 227,39 & Sim \\
\hline Junho & 72,0 & 23,26 & 189,55 & Sim \\
\hline Julho & 38,71 & 23,26 & 225,48 & Sim \\
\hline Agosto & 58,06 & 23,26 & 240,76 & Sim \\
\hline Setembro & 68,0 & 23,26 & 250,76 & Sim \\
\hline Outubro & 139,35 & 23,26 & 288,53 & Sim \\
\hline Novembro & 184,0 & 23,26 & 311,97 & Sim \\
\hline Dezembro & 228,39 & 23,26 & 332,48 & Sim \\
\hline
\end{tabular}

Os critérios para certificação foram novamente comparados após a integração do sistema de resfriamento de absorção proposto. A Tabela 13 foi então, novamente refeita. O resultado gerado pela utilização do sistema de resfriamento por absorção quanto aos critérios Passivhaus encontram-se na Tabela 19. 
Tabela 19 - Resultados do programa PHPP com o uso do resfriamento por absorção

\begin{tabular}{|c|c|c|c|}
\hline \multicolumn{4}{|c|}{$\begin{array}{c}\text { Temperatura Interna limite } \\
20-25^{\circ} \mathrm{C}\end{array}$} \\
\hline \multicolumn{4}{|c|}{$\begin{array}{c}\text { Umidade interna máxima } \\
75 \% \\
\end{array}$} \\
\hline Critérios & $\begin{array}{c}\text { Valores máximos per- } \\
\text { mitidos para certifica- } \\
\text { ção Passivhaus }\end{array}$ & $\begin{array}{l}\text { Edificação Passivhaus } \\
\text { no Rio de Janeiro }\end{array}$ & $\begin{array}{l}\text { Atingiu o crité- } \\
\text { rio de certifica- } \\
\text { ção? }\end{array}$ \\
\hline $\begin{array}{l}\text { Demanda energética } \\
\text { para climatização }\end{array}$ & $15 \mathrm{kwh} / \mathrm{m}^{2}$.ano & $\leq 15 \mathrm{kwh} / \mathrm{m}^{2}$.ano & Sim \\
\hline $\begin{array}{l}\text { Frequência de supe- } \\
\text { raquecimento anual }\end{array}$ & $10 \%$ & 0 & Sim \\
\hline $\begin{array}{c}\text { Frequência anual de } \\
\text { umidade acima de } \\
75 \%\end{array}$ & $10 \%$ & 0 & Sim \\
\hline
\end{tabular}

Com o pleno funcionamento do sistema de resfriamento por absorção instalado, a demanda de energia térmica para climatização do ambiente foi reduzida a ponto de se obter uma certificação Passivhaus de construção, além de ser capaz de gerar água quente para o consumo dos ocupantes da edificação.

A frequência de superaquecimento anual do ambiente foi controlada. Caso a temperatura do ambiente interno da edificação se encontre acima de $25^{\circ} \mathrm{C}$, o sistema de resfriamento é acionado, absorvendo energia térmica do ambiente, ocasionando a redução de sua temperatura.

A frequência de umidade acima do limite máximo estipulado pela norma foi controlada através da retirada do calor latente existente dentro da edificação, através do sistema de resfriamento por absorção apresentado. Assim como o superaquecimento, caso o ambiente se encontre com uma umidade relativa acima de $75 \%$, o sistema de resfriamento é acionado, reduzindo-a.

O excedente de energia térmica gerada nos coletores solares foi suficiente para abastecer por completo a demanda de água quente para uso doméstico dos habitantes da edificação. Assim, obteve-se uma redução quanto ao consumo de energia elétrica requerida pela residência, devido a uma menor demanda de sistemas de aquecimento por passagem da água.

Observou-se que o dimensionamento da energia térmica a ser retirada da edificação objetiva atingir $25^{\circ} \mathrm{C}$, com uma umidade relativa de $75 \%$, ambos preconizados pela normativa. Caso haja uma redução da temperatura limite máxima da edificação, fruto de diferentes temperaturas de conforto, os painéis solares devem ser capazes de fornecer energia ao sistema de resfriamento por absorção para 
absorver cargas térmicas maiores. Assim, um excedente de energia térmica armazenada se faz necessário para suprir diferentes temperaturas de conforto. 


\section{7. \\ Conclusões}

\section{1}

\section{Considerações finais sobre o trabalho}

A norma/certificação Passivhaus foi inicialmente desenvolvida para climas do centro-europeu, onde, convencionalmente, utiliza-se a energia térmica para a manutenção das condições de conforto no interior da edificação. O uso do recuperador de calor tornou-se essencial para o aquecimento de seu ambiente de forma passiva. Para sua adaptabilidade a climas tropicais quentes e úmidos, a edificação deve seguir estratégias opostas, sendo capaz de retirar o calor acumulado. Desta forma, alcançou-se o dimensionamento de uma edificação energeticamente eficiente fazendo uso do sistema de resfriamento por absorção abastecido por energia solar.

Como método comparativo para o estudo de caso, estabeleceu-se parâmetros iniciais de uma edificação localizada no município do Rio de Janeiro, a ser utilizada como modelo inicial. O cálculo de seu balanço térmico foi realizado através do programa Passive House Planning Package, resultando em uma carga térmica anualmente acumulada de $97,5 \mathrm{kwh} / \mathrm{m}^{2}$.ano. Mudanças arquitetônicas e o uso de diferentes elementos construtivos foram simulados, com sua devida influencia na carga térmica total da edificação aferida, através do PHPP.

Como resultado do uso dos elementos arquitetônicos estabelecidos pela Passivhaus, a edificação analisada obteve uma redução de 50,3 \% de sua carga térmica em comparação ao modelo inicial. Esse fato comprova a eficiência da certificação quanto à redução do consumo de energia da edificação, de forma passiva.

O modelo de edificação final que obteve o melhor desempenho energético, possui uma carga térmica anualmente acumulada de $48,5 \mathrm{kwh} / \mathrm{m}^{2}$, valor esse expressivamente inferior ao modelo inicial, porém, superior ao critério para certificação Passivhaus. Desta forma, fez-se uso do sistema de resfriamento por absorção, utilizando energia solar, para adequar a edificação aos critérios limites estabelecidos. 
Apesar do rendimento energético entre o recuperador de calor e o refrigerador de absorção não ser semelhante (necessidade de uma carga térmica superior para refrigerar o ambiente), a energia térmica gerada no estudo de caso foi capaz de suprir a demanda do sistema de resfriamento por absorção e do consumo de água quente para uso doméstico. Na sequência da pesquisa, outras possibilidades da arquitetura passiva, assim como o uso de diferentes materiais construtivos, foram testadas no programa PHPP.

Salienta-se que os limites mínimo e máximo de temperatura determinados pela normativa $\left(20-25^{\circ} \mathrm{C}\right.$, respectivamente) e a padronização da umidade relativa ideal, referente a $75 \%$, devem ser estudados para diferentes condições climáticas. Esses valores, referentes aos critérios para certificação, foram determinados para uma edificação de clima temperado no centro-alemão, onde a norma/certificação teve origem.

Assim, apesar de serem utilizados valores de conforto térmico preconizados pela normativa no estudo de caso, variações na umidade relativa e nos limites de temperatura devem ser analisadas conforme a localidade da construção.

Evidencia-se, portanto, que o trabalho realizado não teve pretensão de esgotar a temática de edificações que fazem uso da arquitetura passiva em climas quentes, mas de fomentar discussões e no desenvolvimento de residências mais eficientes, objetivando a redução do consumo de energia para o conforto térmico de seus habitantes. O uso do resfriamento por absorção no Brasil não é comum, porém é utilizado em outras partes do mundo, como nos Estados Unidos, Japão e países do continente Asiático. Propõe-se desenvolver novas formas de seu aproveitamento fazendo uso de energias renováveis.

A explosão populacional e a falta de planejamento urbano impactam diretamente o consumo dos recursos naturais. A adoção de residências termicamente mais eficientes, abastecidas por energias renováveis, reduzem tais impactos.

\section{2}

\section{Recomendações futuras}

As recomendações futuras estão relacionadas ao aprimoramento da metodologia construtiva de edificações que fazem uso da arquitetura passiva em climas 
quentes, incluindo a real construção de uma edificação certificada pela Passive House Institute.

Como forma de consolidar no mercado o uso do programa PHPP em climas quentes, é necessária a validação do programa frente a demais softwares de carga térmica já validados (Energy Plus). A entrada no mercado de softwares capazes de dimensionar o balanço térmico da edificação corrobora para a ratificação da eficiência energética de construções.

Acredita-se que sejam necessários avanços nas pesquisas que contribuam para a melhoria do conforto térmico interno da edificação, com a redução de seu consumo energético, assim como o uso de energias renováveis para seu suprimento. Essas soluções corroboram com a sustentabilidade do meio ambiente, diminuindo impactos econômicos e ambientais para as gerações futuras. 


\section{8. \\ Referências bibliográficas}

ALEMANHA. German Institute for Standardization - DIN 1946. Ventilation and air conditioning - part 6: Ventilation for residential buildings- General requirements, requirements for measuring, performace and labeling, delivery/acceptance (certification) and maintenance. Alemanha, 2009.

AQUA-HQE. Alta qualidade ambiental. Desenvolvido pela Fundação Vanzolini, 2008. Apresenta explicações sobre a certificação ambiental AQUA. Disponível em: <http://vanzolini.org.br/aqua/>. Acesso em: 03 mar. 2016.

ARA, P. J. S. Desempenho de sistemas de condicionamento de ar com utilização de energia solar em edifícios de escritórios. São Paulo, 2010. 192p. Dissertação (Mestre em Engenharia Civil) - Faculdade de Engenharia, Universidade de São Paulo, Escola Politécnica.

ARASTEH, D. et al. Window Systems for High-Performance Buildings. Nova York: Norton \& Company, Inc. 2004.

ASHRAE. Ventilation for acceptable indoor air quality. ANSI/ASHRAE Standard 62-1989. 1989.

AVILA, A.M.H,. Uma Síntese do Quarto Relatório do IPCC. Revista Multiciência, Campinas, abril. 2007. Disponível em: https://www.multiciencia.unicamp.br/artigos_08/r01_8.pdf Acesso em: 28 nov.2015.

BRASIL. Associação Brasileira de Normas Técnicas - ABNT.NBR 7198: Projeto e execução de instalações prediais de água quente. Rio de Janeiro, 1993.

BRASIL. Associação Brasileira de Normas Técnicas - ABNT.NBR 15.220: Desempenho térmico de edificações -Parte 2: Métodos de cálculo da transmitância térmica, da capacidade térmica, do atraso térmico e do fator solar de elementos e componentes de edificações. Rio de Janeiro, 2005. 
BRASIL. Associação Brasileira de Normas Técnicas - ABNT.NBR 15.220: Desempenho térmico de edificações -Parte 1: Definições símbolos e unidades. Rio de Janeiro, 2005.

BRASIL. Associação Brasileira de Normas Técnicas - ABNT.NBR 15.220: Desempenho térmico de edificações -Parte 3: Zoneamento bioclimático brasileiro e diretrizes construtivas para habitações unifamiliares de interesse social. Rio de Janeiro, 2005.

BRE GLOBAL LTD. BREEAM. Apresenta conteúdos sobre a certificação ambiental BREAM, 1990-2016. Disponível em: < http://www.breeam.com/>. Acesso em: 27 nov. 2015.

BRE GLOBAL LTD. BREEAM New Construction: Non-Domestic Buildings. Technical Manual, 2011. Disponível em:< http://www.breeam.com/breeamGeneralPrint/breeam_non_dom_manual_ 3_0.pdf>. Acesso em 15 nov. 2015.

BRE TRUST. Passivhaus Building Certification. Reino Unido, 2015. 2p.

BRE TRUST. Passivhaus primer: Airtightness Guide. Airtightness and air pressure testing in accordance with the Passivhaus standard. Reino Unido, 2015. 24p.

BRE TRUST. Passivhaus primer: Contractor's guide. So you've been asked to build a Passivhaus?. Reino Unido, 2015. 12p.

BRE TRUST. Passivhaus primer: Designer's guide. A guide for the design team and local authorities. Reino Unido, 2015. 12p.

BRE TRUST. Passivhaus primer: Introduction. An aid to understanding the key principles of the Passivhaus Standard. Reino Unido, 2015. 12p.

CAROSSI, G.A.B. Resfriamento Evaporativo: Estudo do potencial de sua aplicação no Brasil. Uberlândia - Minas Gerais, 2006. 69p. Dissertação (Mestre em Engenharia Mecânica) - Faculdade de Engenharia, Universidade Federal de Uberlândia.

CIB. Agenda 21 para a construção. São Paulo: Escola Politécnica da USP, 2000. Disponível em: ww.cibworld.nl> Acesso em: 21.10.2014.14. Minergie. Desenvolvido pela Minergie Association, 1998. Apresenta explicações sobre a certificação ambiental Minergie. Disponível em: $<$ http://www.minergie.ch/> .Acesso em: 08 jun. 2015. 
CIB. International Council for Research and Innovation in Building and Construction, 1953. Desenvolve e estimula a pesquisa cientifica entre instituições privadas e institutos governamentais na área de construção civil. Disponível em:< http://www.cibworld.nl/site/home/index.html>. Acesso em 03 mar. 2015.

COELHO, L. Certificação ambiental. Revista téchne, 155.ed. São Paulo: Pini, 2010.

CONSUL. CONSUL Geladeiras a querosene. Apresenta conteúdos sobre a primeira geladeira fabricada no Brasil utilizando o resfriamento por absorção. Disponível em http://www.consul.com.br/sobreaconsul/>. Acesso em: 27 nov. 2015.

CRCC. Cool Roof Rating Council. Apresenta conteúdos sobre refletância solar dos diferentes materiais, 2007-2016. Disponível em: http://coolroofs.org/products/results>. Acesso em: 27 nov. 2015.

CUNHA, E. G. \& MACHADO, N. R. S. Verificação da Formação de Mofo e Bolor em Superfícies Interiores de Paredes Exteriores Situadas na Zona Bioclimática 3 de Acordo com a NBR 15220 e PNBR 02.136.01. São Paulo. NUTAU, 2008. 14p.

DEKAY, M; BROWN, G. Z. Sol, Vento \& luz : Estratégias para o projeto de arquitetura. 2.ed. São Paulo: Artmed Editoras. S, 2004. 410p. 24. Berdahl, P. and Bretz, S. Spectral Solar Reflectance of Various Roof Materials, Cool Building and Paving Materials Workshop, Gaithersburg, Maryland, Julho, 1994. 14p.

DESAI, K.K. Efficient Method to cool the data center using solar energy. USA - Texas, 2015. 38p. Master's theses - University of Mechanical Engineering, The University of Texas at Arlington.

DGNB. DGNB System. Apresenta conteúdos sobre a certificação ambiental DGNB, 2007-2016. Disponivel em: http://www.dgnb-system.de/en/>. Acesso em: 27 nov. 2015.

EICKER, U. Design and performance of solar powered absorption cooling systems in office buildings. GER-Stuttgart, 2009. 27p.

ENERGY DESIGN RESOURCES. Design Brief: Radiant Cooling. Colorado: Financial Times Energy, Inc. 2000.

FAU-UFRJ. Bioclimatismo no Projeto de Arquitetura: Dicas de Projeto. Rio de Janeiro, 2005. 66p. 
FOLEY, G. The Future of Absorption Technology in America. A Critical Look at the Impact of BCHP and Innovation. United States, U.S Department of Energy. 2000.12p.

GEMER, V. R. Sistemas de absorção de uso doméstico. São Paulo: SENAI Oscar Rodrigues Alves, 2011.

GUZOWSKI, M. Towards Zero Energy Architecture, New Solar Design. 2.ed. Londres: Laurence King Publishing Ltd, 2012. 2008p.

INTERNATIONAL ENERGY AGENCY. The Energy Situation in Brazil an Overview. Reino Unido, 2006. Disponível em: https://www.iea.org/publications/freepublications/publication/the-energysituation-in-brazil---an-overview.html/>. Acesso em nov. 2015.

INTERNATIONAL PASSIVE HOUSE ASSOCIATION. Active for more Comfort: Passive House. Information for Property Developers, Contractors and Clients. Darmstadt, Alemanha. 2014. Disponível em: < http://www.passivehouse-international.org/upload/ipha-brochure/>. Acesso em nov. 2015.

KUREM, E. \& HORUZ, I. A comparison between ammonia-water and water-lithium bromide solutions in absorption heat transformers. International Communications in Head and Mass Transfer, Volume 28. Abril 2001, páginas 427-438.

LAMBERTS, R. et. al. Desempenho térmico de edificações. Apostila da Disciplina de Desempenho Térmico de Edificações -ECV 5161. Florianópolis: UFSC, 2011.

LEED. Leadership in Energy \& Environmental Design. Desenvolvido pelo US. Green Building Council, 1998. Apresenta explicações sobre a certificação ambiental LEED. Disponível em: < http://www.usgbc.org/articles/about-leed>. Acesso em:12 ago. 2015.

LENGEN, J. V. Manual do Arquiteto Descalço. 1. ed. São Paulo: B4 Ed., 2014. 736p.

LOXONE. Smart Houses. Apresenta conteúdos sobre construções inteligentes, 2005-2016. Disponível em http://www.loxone.com>. Acesso em: 27 nov. 2015.

LIBRELOTTO, G.R. Comparação entre os critérios de avaliação envolvidos nos sistemas de certificação de edificações AQUA E 
LEED for Schools, 2010. 114p. Monografia (Especialização em Engenharia Civil) - Faculdade de Engenharia, Universidade Federal do Rio Grande do Sul.

MASCARÓ, L. Energia na edificação: estratégia para minimizar seu consumo. 2.ed. São Paulo: Projeto Editores Associados Ltda, 1991. 213p.

METZ, B.; DAVIDSON, O.R.; BOSCH, P.R.; DAVE, R. Climate Change 2007: Mitigation. Contribution of Working Group III to the Fourth Assessment Report of the Intergovernmental Panel on Climate Change. Cambridge University, feb. 2007. Disponível em: $<$ https://www.ipcc.ch/pdf/assessmet-report/ar4/wg3/ar4_wg3_full_report. pfd> Acesso em: 20 nov. 2015.

NANOTECH. Tintas Refletoras. Apresenta conteúdos sobre tintas de alta refletância térmica. Disponível em http://www.nanotechdobrasil.com.br>. Acesso em: 27 nov. 2015.

ORDENES, M.; LAMBERTS, R.; GUTHS, S. Transferência de calor na envolvente da edificação, Florianópolis, março de 2008. Disponível em: $<$ http://www.labeee.ufsc.br/sites/default/files/disciplinas/Apostila_08.pdf>. Acesso em: 23 dez. 2015.

PASSIVE HOUSE INSTITUTE. Certifications as "Quality Approved Passive House". Criteria for Non-Residential Passive House Buildings. 1.ed. Alemanha, 2009. 8p.

PASSIVE HOUSE INSTITUTE. Certifications as "Quality Approved Passive House". Criteria for Residential Passive House Buildings. 1.ed. Alemanha, 2009. 7p.

PASSIVE HOUSE INSTITUTE. Criteria for the Passive House, EnerPhit and PHI Low Energy Building Standard. ed.9. Alemanha, 2015. 25p.

PASSIVE HOUSE INSTITUTE. Passive House Planning Package: the energy balance and design tool for efficient buildings and retrofits. 9.ed. Alemanha: Passive House Institute, 2015.

PASSIVE HOUSE INSTITUTE. The Passive House Concept for Different Climate Zones. Implementing the Concept in New Contexts. 1.ed. Alemanha, 2010. 26p.

PASSIVHAUS TRUST. How to Build a Passivhaus: Rules of Thumb. Baldwin Terrace, Londres. 2015. Disponível em: 
https://issuu.com/passivhaus_trust/docs/how_to_build_a_passivhaus_rule s_of_/1> Acesso em 20 dez. 2015.

RIBEIRO, R. Acondicionamento Térmico Natural Arquitetura e Clima. 2.ed. Curitiba: D.C. Luzzato, 1986. 240p.

ROAF, S.; CRICHTON, D.; NICOL, F. Adapting Building and Cities for Climate Change. 2.ed. Reino Unido: Linacre House, 2005. 385p.

SANTOS, R. B.; COSTA, C. M.; BRASIL, P. C. Sustantabilidade nas edificações comerciais: uma abordagem da certificação AQUA - Alta Qualidade Ambiental. In: $3^{\circ}$ Seminário Nacional de Construções Sustentáveis. 2014.

Disponível em:< https://www.imed.edu.br/Uploads/Sustentabilidade\%20nas\%20edifica\%C3 $\%$ A7\%C3\%B5es\%20comerciais_uma\%20abordagem\%20da\%20certifica \%C3\%A7\%C3\%A30\%20AQUA-Alta\%20Qualidade\%20Ambiental.pdf>. Acesso em 08.dez. 2015.

SBRAVATI, A.; SILVA, A.F.S. Refrigeração por absorção. São Paulo: Universidade Estadual de Campinas, 2005.

SCHNIEDERS, J. Passivhauss in South West Europe. Darmstadt, Passivhaus Institut, 2009.

SUSTAINABLE BUILDING ALLIANCE. Piloting SBA Common Metrics. 1.ed. Europa, 2014. 120p.

TIBA, C. et al. Atlas Solarimétrico do Brasil: banco de dados solarimétricos, Recife. 2000. Disponível em: < http://www.cresesb.cepel.br/publicacoes/download/Atlas_Solarimetrico_do _Brasil_2000.pdf>. Acesso em: 23 dez. 2015.

TRIPLE E CONSULTING - ENERGY, ENVIROMENT \& ECONOMICS B.V. Market Study for a Voluntary Common European Union Certification Scheme for the Energy Performance of Non-Residencial Buildings. Rotterdam, Holanda. 2014. Disponível em :< https://ec.europa.eu/energy/sites/ener/files/documents/Final\%20report\%20 -\%20Building\%20Certification\%20Schemes\%20-

\%20FINAL\%2026112014.pdf>. Acesso em 18 nov. 2015.

TUBELO, R.C.S.; RODRIGUES, L.T.; GILLOTT, M. A Comparative Study of the Brazilian energy Labelling System and the Passivhaus Standard for Housing. Reino Unido, 2014. 15p. Artigo - Faculdade de Engenharia, Universidade de Nottingham.

UNFCCC, Mitigation benefits of actions, initiatives and options to enhance mitigation ambition, technical papel. Reino Unido, 2015. 90 p. 
USGBC. LEED. Apresenta conteúdos sobre a certificação ambiental LEED, 2000-2016. Disponível em http://www.usgbc.org/about>. Acesso em: 27 nov. 2015.

WASSOUF, M. De la casa pasiva al esándar Passivhaus: la arquitectura passiva em cálidos. 1.ed. Espanha: Gustavo Gili, 2014. 143p.

WHITE, T. W. How Absorption refrigeration works, USA. 2015. Disponível em:

< http://vintageservelrefrigerators.8k.com/HowltWorks.html>. Acesso em 20 mar. 2015.

YANNAS, S.; CORBELLA, O. Em busca de uma arquitetura sustentável para os trópicos. 1.ed. Rio de Janeiro: Raven, 2003. 288p. 